\title{
NEUTRAL TAXATION OF CAPITAL INCOME: AN ACHIEVABLE GOAL?
}

\author{
Pamela B. GanN*
}

The U.S. government is expected to provide macroeconomic management to minimize unemployment and inflation and to maintain productivity growth. This management function did not appear to be performed adequately during the late 1970's or early 1980's since the United States experienced unemployment, inflation, and a decline in productivity growth. ${ }^{1}$ During this period, critics (often referred to as "supply-siders") of government economic management focused on issues of capital formation. They argued that the

Copyright $\odot 1985$ by Law and Contemporary Problems

* Professor of Law, Duke University, Durham, North Carolina. While writing this article, the author was an International Affairs Fellow of the Council on Foreign Relations and a guest-inresidence of the Fiscal Affairs Department of the International Monetary Fund. The author thanks the Council and, in particular, Vito Tanzi, Director, and Leif Muten, Senior Advisor, of the Fiscal Affairs Department for their excellent colleagueship during her visit with the Fund.

1. This footnote summarizes relevant economic data.

TABLE 2

GNP Growth Rates

(1972 Constant Dollars)

TABLE 1

GNP Implicit Price Deflator

\begin{tabular}{lc}
\hline Year & Deflator \\
\hline 1977 & 5.8 \\
1978 & 7.4 \\
1979 & 8.6 \\
1980 & 9.2 \\
1981 & 9.4 \\
1982 & 6.0 \\
1983 & 4.2 \\
\hline
\end{tabular}

Source: Council of Economic Advisors, Economic Report of THE PRESIDENT 225 (Table B-3) (1984) [hereinafter cited as Economic Report of the PresiDENT 1984]. YEAR)

\begin{tabular}{lr}
\hline Year & Percentage \\
\hline 1978 & 5.0 \\
1979 & 2.8 \\
1980 & -0.3 \\
1981 & 2.6 \\
1982 & -1.9 \\
1983 & 3.3
\end{tabular}

Source: Economic Report of the PresiDENT 1984, at 223 (Table B-2). 
United States saves too little, ${ }^{2}$ and that this leads to a shortfall in investment and a decline in productivity growth. They placed much of the blame on the interaction of inflation and an unindexed income tax base. Such a system taxes nominal interest rates (rather than the lower real interest rates) and allows depreciation expense based on historical cost accounting methods (rather than on the higher real costs of replacing capital), thereby yielding too high an effective tax rate on capital income. These higher taxes, they argued,

TABLE 3

UNEMPLOYMENT RATE

\begin{tabular}{lc}
\hline Year & Percentage \\
\hline 1970 & 4.8 \\
1975 & 8.3 \\
1976 & 7.6 \\
1977 & 6.9 \\
1978 & 6.0 \\
1979 & 5.8 \\
1980 & 7.0 \\
1981 & 7.5 \\
1982 & 9.5 \\
1983 & 9.5 \\
\hline
\end{tabular}

Source: ECONOMIC REPORT OF THE PRESIDENT 1984, at 259 (Table B-33).

2. The United States personal saving rate is low relative to other developed countries. The following table compares the saving rate of various countries.

TABLE 5

Ratio of Personal Savings to Disposable Personal Income

\begin{tabular}{rccccccrr}
\hline Year & $\begin{array}{c}\text { United } \\
\text { States }\end{array}$ & France & Germany & Italy & Netherlands & $\begin{array}{c}\text { United } \\
\text { Kingdom }\end{array}$ & Japan & Canada \\
\hline 1970 & 8.0 & 16.7 & 14.6 & 21.6 & 14.0 & 9.0 & 18.2 & 5.3 \\
1976 & 6.9 & 16.4 & 14.7 & 22.9 & 14.6 & 11.9 & 22.4 & 10.0 \\
1977 & 5.6 & 16.6 & 13.6 & 22.5 & 12.0 & 10.8 & 21.0 & 9.7 \\
1978 & 5.2 & 17.5 & 13.7 & 23.8 & 11.9 & 12.7 & 20.6 & 10.8 \\
1979 & 5.2 & 15.9 & 14.4 & 25.3 & 11.6 & 14.1 & 18.6 & 10.3 \\
1980 & 5.6 & 14.3 & 14.5 & 22.0 & 12.4 & 15.1 & 19.4 & 10.1 \\
1981 & 5.3 & 14.8 & 15.2 & - & - & 13.7 & - & 11.6 \\
\hline
\end{tabular}

Source: U.S. Dep't of Commerce, Statistical Abstract of the United States 1982-83, at 422 (Table 697) (1984).

International comparisons of personal saving rates can be misleading. They do not include business saving by corporations, and the gaps in saving rates may be attributable in part to differences in the use of the corporate form of doing business and the extent to which corporations retain their earnings rather than pay dividends. Bosworth argues, for example, that the more useful data is the total saving rate in the United States (personal, corporate, and government), and when this data is observed, the U.S. total saving rate has not declined. Bosworth, Capital Formation and Economic Policy, 1982 Brookings Papers on Econ. Activity 273, 302-05; see B. Bosworth, Tax Incentives and ECONOMIC Growtr 62-67 (1984). The following table shows that total gross private saving has been very stable, but the mix has changed in that business saving is a larger percentage of total private saving. 
caused lower after-tax rates of return to investment which in turn reduced the propensity to save and to invest. This view of the cause of the claimed

TABle 6

Private Saving in Relation to GNP

(Five-Year Periods)

\begin{tabular}{lccc}
\hline & \multicolumn{3}{c}{ Average Percentage of GNP } \\
\cline { 2 - 4 } Period & $\begin{array}{c}\text { Gross Private } \\
\text { Saving }\end{array}$ & $\begin{array}{c}\text { Personal } \\
\text { Saving }\end{array}$ & $\begin{array}{c}\text { Business } \\
\text { Saving }\end{array}$ \\
\hline $1948-1950$ & 14.9 & 4.2 & 10.7 \\
$1951-1955$ & 15.7 & 4.7 & 11.0 \\
$1956-1960$ & 16.4 & 4.7 & 11.7 \\
$1961-1965$ & 16.4 & 4.4 & 12.0 \\
$1966-1970$ & 16.3 & 5.0 & 11.3 \\
$1971-1975$ & 17.0 & 5.7 & 11.3 \\
$1976-1980$ & 16.9 & 4.2 & 12.7 \\
1981 & 17.3 & 4.6 & 12.7 \\
1982 & 17.0 & 4.1 & 12.9 \\
1983 & 17.2 & 3.4 & 13.7 \\
\hline
\end{tabular}

Source: Calculated by author from data in ECONOMIC REPORT OF THE PRESIDENT 1984, supra note 1, at 220, 250 (Tables B-1, B-25).

Kotlikoff has noted, however, that although the ratio of gross private saving to GNP has been stable, arguably this figure may be misleading because it is based on accounting conventions. Kotlikoff, Taxation and Savings: A Neoclassical Perspective, 22 J. ECON. LTTERATURE 1576, 1582 (1984). In particular, gross private saving is the difference between gross national saving and the National Income and Product Accounts (NIPA) definition of government deficits, which is an "entirely arbitrary accounting choice." Id. at 1582. Accordingly, the gross private saving amount is also arbitrary. Kotlikoff calculates the net national saving rate, capitalizing capital expenditures and including imputed rental income on capital assets less depreciation. Id. at 1580 . The following table displays his calculations and shows that the net national saving rate has not been constant since 1950 .

TABLE 7

Indices of U.S. SaVing Behavior: 1930-1982

(Average Annual Rate Over Specified Period)

(Percent)

\begin{tabular}{cccccc}
\hline \hline & $\begin{array}{c}\text { Net } \\
\text { National } \\
\text { Saving } \\
\text { Rate }\end{array}$ & $\begin{array}{c}\text { Net National } \\
\text { Saving Rate } \\
\text { (NIPA Basis) }\end{array}$ & $\begin{array}{c}\text { Household* } \\
\text { Consumption } \\
\text { Rate } \\
\text { (C/NNP) }\end{array}$ & $\begin{array}{c}\text { Government* } \\
\text { Consumption } \\
\text { Rate } \\
\text { (G/NNP) }\end{array}$ & $\begin{array}{c}\text { Rate of* } \\
\text { Household } \\
\text { Consumption } \\
\text { Out of } \\
\text { Disposable NNP } \\
\text { (C/NNP-G) }\end{array}$ \\
\hline $1930-1939$ & -1.17 & -2.86 & 87.66 & 13.51 & 101.49 \\
$1940-1949$ & 10.23 & 5.32 & 68.35 & 21.42 & 87.29 \\
$1950-1959$ & 15.60 & 8.79 & 67.64 & 17.02 & 81.60 \\
$1960-1969$ & 14.25 & 8.71 & 65.35 & 20.40 & 82.09 \\
$1970-1979$ & 11.90 & 7.70 & 67.10 & 21.00 & 84.92 \\
$1980-1982$ & 7.04 & 5.07 & 68.62 & 24.35 & 90.71 \\
\hline \hline
\end{tabular}

*Household consumption, C, equals NIPA personal nondurables consumption expenditures plus inputed rent on household durables. Government consumption, G, equals NIPA government nondurables consumption expenditures plus imputed rent on government tangible assets, including military hardware. NNP equals NIPA NNP plus imputed rent on household durables and government tangible assets less depreciation of these assets. 
shortfall in capital formation has had a tremendous impact on development of U.S. fiscal policy by the Reagan Administration.

The Economic Recovery Tax Act of 1981 (ERTA) ${ }^{3}$ reflected supply-side tax policy by including across-the-board reductions in tax rates, indexation of rates, exemptions, and zero bracket amounts for inflation, and additional provisions to reduce the effective tax rate on savings. Congress expected that these provisions would increase the after-tax rate of return on savings and thus also increase the level of savings. These savings were then to be directed into business capital formation by the inclusion of substantial incentive provisions to invest in business capital, causing a shift in the allocation of investment. Curiously, although the perceived problem of high effective tax rates on capital income resulted in part from the interaction of inflation with an unindexed income tax base, that problem was not directly addressed by the indexation of interest, basis in assets, and depreciation deductions.

Economists recently have paid particular attention to issues of capital income taxation which are critical to the appropriateness of the Reagan Administration's tax policy. Section I of this paper reviews the supply-side debate concerning proper fiscal management by the federal government. It then examines public finance research to determine the extent to which that research supports the Reagan Administration's tax policy. It concludes that, although this research has contributed substantial empirical advances to the analysis of the issues, the debate within economic circles is unfinished and does not yield unanimous support for the 1981 legislative changes. Nevertheless, one area of consensus has emerged from the research.

Id. at 1581 (Table 1).

Kotlikoff also calculated comparative net saving rates using OECD data. These calculations, displayed in the following table, show that the U.S. net saving rate is persistently lower than European OECD countries and Japan.

TABLE 8

Saving and Consumption Rates: International Comparisons

\begin{tabular}{|c|c|c|c|c|c|c|c|c|c|}
\hline \multirow[t]{2}{*}{ Period } & \multicolumn{3}{|c|}{$\begin{array}{l}\text { Net National } \\
\text { Saving Rate }\end{array}$} & \multicolumn{3}{|c|}{$\begin{array}{l}\text { Government } \\
\text { Consumption } \\
\text { Rate: G/NNP }\end{array}$} & \multicolumn{3}{|c|}{$\begin{array}{c}\text { Household } \\
\text { Consumption } \\
\text { Rate: } \mathrm{C} /(\mathrm{NNP}-\mathrm{G}) \\
\text { Out of Disposable NNP } \\
\end{array}$} \\
\hline & U.S. & $\begin{array}{l}\text { OECD } \\
\text { Europe }\end{array}$ & Japan & U.S. & $\begin{array}{l}\text { OECD } \\
\text { Europe }\end{array}$ & Japan & U.S. & $\begin{array}{c}\text { OECD } \\
\text { Europe }\end{array}$ & Japan \\
\hline $\begin{array}{l}1955-1959 \\
1960-1969 \\
1970-1979 \\
1980-1981 \\
\end{array}$ & $\begin{array}{r}9.8 \\
10.5 \\
8.0 \\
5.0\end{array}$ & $\begin{array}{l}\text { NA } \\
17.3 \\
15.1 \\
11.0\end{array}$ & $\begin{array}{l}21.5 \\
17.0 \\
25.5 \\
21.3\end{array}$ & $\begin{array}{l}19.1 \\
20.1 \\
20.1 \\
20.9\end{array}$ & $\begin{array}{l}\text { NA } \\
15.7 \\
18.5 \\
19.9\end{array}$ & $\begin{array}{r}10.6 \\
9.4 \\
10.4 \\
11.7\end{array}$ & $\begin{array}{l}87.9 \\
86.9 \\
89.9 \\
93.6\end{array}$ & $\begin{array}{l}\text { NA } \\
79.8 \\
81.5 \\
86.3\end{array}$ & $\begin{array}{l}76.0 \\
70.2 \\
70.5 \\
75.9\end{array}$ \\
\hline $1960-1981$ & 8.7 & 15.7 & 25.8 & 20.2 & 17.3 & 10.1 & 88.9 & 81.0 & 71.3 \\
\hline
\end{tabular}

Source: OECD (1983); variables are defined according to U.N. System of National Accounts. NA $=$ Not available.

Id. at 1584 (Table 2). The OECD definitions are similar to those used in the U.S. NIPA, except that government consumption excludes expenditures on nonmilitary durables and structures. Id. at 1583-84.

3. Pub. L. No. 97-34, 95 Stat. 172. 
Economists on the whole agree that the interaction of inflation, an unindexed income tax base, and capital investment incentives yields varying effects across types of industry and investment, thereby inefficiently creating misallocation of capital.

Section II summarizes the relevant changes made by ERTA and subsequent legislation and discusses the extent to which they respond to the inflation arguments utilized by the Administration to support the 1981 changes. This part shows that given the Administration's description of the problem as one closely linked to inflation, the chosen solution of increased depreciation deductions and investment tax credits did not directly (or correctly) address the problem of inflation and an unindexed income tax base. The chosen solution also perpetuates substantial inefficiency by continuing the misallocation of capital investment. This section also summarizes recent research addressing the issue whether the substantial increase in tangible capital investment which occurred in 1983-1984 is significantly attributable to the tax changes under ERTA. This research raises substantial doubts about their connection, thereby leaving unsettled the correctness of the economic arguments underpinning ERTA.

A substantial consensus exists, however, that the income tax needs to be modified to achieve increased neutrality in the taxation of capital. Neutrality in this sense means that investor choice among assets remains as unaffected as possible by the imposition of the income tax. Section III discusses the "ideal" features of an income tax to achieve this neutrality and also the extent to which these features, or adequate proxies for these features, could be incorporated into our income tax.

Section IV reviews four of the so-called base-broadening, flatter income tax proposals, two from members of Congress, one from the Treasury Department, and the last from President Reagan, to determine to what extent they achieve neutrality with respect to income taxation of capital. Those readers who are familiar with the arguments which formed the basis for ERTA and with the degree of nonneutrality in the present income tax may wish to begin their reading at Section III.

\section{A Description of the Debate}

\section{A. Why is Capital Accumulation Important?}

Economists argue that higher levels of capital formation are needed for several reasons. ${ }^{4}$ First, we desire a higher standard of living and capital

4. For a summary of these arguments, see, for example, Malkiel, The Capital Formation Problem in the United States, 34 J. Fin. 291 (1979); Vaccara, Some Reflections on Capital Requirements for 1980, 67 AM. ECON. Rev. 122 (1977); Vaccara, The Why and How of Increased Fixed Capital Formation, in D. Kiefer, Capital formation, Productivity Growth, and Tax Policy: A Reader 11 (Cong. Research Service Rep. No. 80-30E, 1980). For a critique of the view that the United States would benefit from higher levels of capital formation, see Eisner, Capital Shorlage: Myth and Reality, 67 Am. Econ. Rev. 110 (1977). 
accumulation is an important source of the economic growth needed to attain higher real wages and therefore higher standards of living. Second, countries establish national goals which require more capital accumulation. In the United States these goals include, for example, higher levels of employment, a cleaner environment, a safer workplace, inner city rebuilding, and less reliance on foreign energy resources. Third, increased rates of labor force growth have not been matched by equivalent increased rates of capital growth. Lower capital to labor ratios result in lower labor productivity, which in turn produces a decline in the level of real wages in the long-run. Low capacity can also limit the ability to sustain full employment. ${ }^{5}$

The Reagan Administration linked the disappointing economic results in the 1970's to inadequate capital formation, and attributed this shortfall largely to the interaction of inflation and an unindexed income tax base. 6 The next section describes this argument which links tax policy to capital formation and productivity decline. Feldstein has contributed substantially to the promotion of this viewpoint and references to his arguments accordingly dominate the next part.

\section{B. Tax Policy and Capital Formation}

The dominant prescription, prior to the Reagan Administration, for increasing capital formation and productivity growth had been a mixture of monetary ease and fiscal resiraint. ${ }^{7}$ Monetary ease is designed to encourage investment by lowering interest rates. It assumes that lower rates stimulate investment more than they deter savings. Fiscal restraint, either by tax increases or reduced public expenditures, limits demand and reduces consumption more than it reduces investment. Economists have noted that

5. Feldstein argues that the saving rate should be higher because there exists an intertemporal misallocation of consumption. He estimates that the rate at which individuals discount future consumption is less than the national rate of return on private investment; therefore, the United States should save more until these rates of return are equivalent. Feldstein, Does the United States Save Too Little?, 67 Am. Econ. Rev. 116 (1977); accord, Summers, Comments and Discussion [of Bosworth, supra note 2], 1982 Brookings Papers on Econ. Actrvity 321, 322.

6. For a simple, nontechnical presentation of the Reagan Administration's position, see Address by Norman B. Ture, Undersecretary of the Treasury for Tax and Economic Affairs, Lehigh University (March 31, 1982), reprinted in 15 TAx Notes 235 (1982). For a critique of this speech, see Letter from Robert McIntyre to the Editor, 15 TAX Notes 577 (1982).

7. For a summary of this economic mix, see, for example, B. Bosworth, supra note 2, at 11-12; Feldstein, Inflation and the American Economy, 67 PUB. INTEREST, Spring 1982, at 63, 74; Feldstein, Tax Rules, and the Mismanagement of Monetary Policy, 70 AM. Econ. REv. 182 (1980); Tobin, Stabilization Policy Ten Years After, 1980 Brookings PAPERs on Econ. Activiry 19, 52-53. The Joint Committee on Taxation has described this policy as follows:

When an economy is operating well below its capacity, all that is generally needed to achieve more capital accumulation is for there to be an increase in the willingness of businesses or individuals to invest-to purchase new plant, equipment, housing, inventories and other items. Such investment stimulates the economy and creates new jobs and income; and the additional saving out of this additional income will be sufficient to finance the additional investment. This process by which investment spending in an underemployed economy generates growth in income, and hence in saving, through the multiplier effect is the basic feature of Keynesian economies [sic].

Staff of Joint Comm. on Taxation, 95th Cong., 1st Sess., Tax Policy and Capital Formation 5-6 (Comm. Print 1977) [hereinafter cited as Jt. Comm. Print]. 
this growth-oriented policy is hard to achieve politically. Tobin stated that the opposite mix is the more natural government response to management problems: fiscal ease to fight unemployment and recession and monetary restriction to attack inflation. ${ }^{8}$ Feldstein argued that the monetary ease and fiscal restraint policy mix has failed (as evidenced by persistent inflation and low rates of productivity growth in the United States) because it was designed to stimulate demand in a slack economy. ${ }^{9}$ It had been applied in the 1970's, however, in a full employment economy, and Feldstein argued that this policy mix operated in this circumstance substantially to curtail rather than to promote productivity growth, because inflation and higher nominal rates then resulted. ${ }^{10}$ These higher nominal rates made the cost of borrowing appear high, when in fact it was low because of the interaction of nominal interest rates and the tax system. " Real interest rates were stable and nominal interest rates roughly equalled the real interest rate plus the expected inflation rate. Borrowers deducted for income tax purposes nominal rather than real interest rates so that the after-tax interest cost was much lower than the nominal interest rate itself. Moreover, the real after-tax cost of borrowing decreased as nominal interest rates increased due to general price level changes, thereby lowering rather than increasing costs of borrowing.

Table 1 illustrates these points. Assume that the real interest rate is $4 \%$, and that the marginal rate of the borrower is $50 \%$. Table 1 shows, at various inflation rates, the nominal after-tax cost and the real after-tax cost of borrowing. The figures in Table 1 are based on the assumption that nominal interest rates equal the real interest rate plus the expected inflation rate. Because the nominal interest rate is subject to tax, it must increase by more than the inflation rate for the real after-tax interest rate to remain constant. ${ }^{12}$ Factors other than inflation can affect the level of interest rates, however, and empirical evidence suggests that nominal U.S. interest rates have been close to the sum of the real interest rate plus the expected inflation rate. ${ }^{13}$

8. Tobin, supra note 7 , at 53 .

9. M. Feldstein, Inflation, Tax Rules, and Capital Formation 13-14 (1983); Feldstein, Inflation and the American Economy, supra note 7, at 74-75; see also Feldstein, Monetarism: Open-Eyed Pragmatism, The EConomist, May 18, 1985, at 17.

10. Feldstein, Inflation and the American Economy, supra note 7, at 75. The Joint Committee on Taxation has described this policy as follows:

When an economy is operating at a high level of employment, however, an increase in the willingness to invest without a corresponding increase in the willingness to save will lead to inflation and higher interest rates and will result in little additional investment. At full employment, there can be no further economic expansion to generate additional saving to finance the investment, and at such times, an increase in investment must be accompanied by a corresponding increase in the willingness to save.

Jt. Comm. Print, supra note 7 , at 6.

11. For his discussion of this point, see M. Feldstein, supra note 9, at 10; Feldstein, Tax Rules and the Mismanagement of Monetary Policy, supra note 7.

12. Much has been written about inflation's effect on market interest rates and real after-tax rates of return. For a summary of some of this literature, see, for example, M. KING \& D. FULLERTON, The Taxation of Income from Capital $291-95$ (1984); Bosworth, supra note 2, at 299-302. For a more thorough discussion of the interaction of interest rates, inflation, and the income tax, see infra text accompanying notes $197-201$.

13. See infra note 201 . 
Accordingly, as shown in Table 1, and consistent with Feldstein's argument, the real after-tax cost of borrowing declined, even though the nominal cost of borrowing during the 1970's increased. Feldstein claims that monetary authorities, considering only nominal interest costs, mistakenly eased credit conditions further to lower the nominal costs and thereby caused the macroeconomic policy to be tọ stimulative. ${ }^{14}$

TABLE 1

Nominal and Real After-Tax Cost of Borrowing at Various INFLATION RATES AT 50\% MARginal TAX RATE

\begin{tabular}{ccccc}
$\begin{array}{c}\text { Column } \\
\text { A }\end{array}$ & $\begin{array}{c}\text { Column } \\
\text { B }\end{array}$ & $\begin{array}{c}\text { Column C } \\
(\mathrm{A}+\mathrm{B})\end{array}$ & $\begin{array}{c}\text { Column D } \\
(\mathrm{C} \times(1-0.5)\end{array}$ & $\begin{array}{c}\text { Column } \mathrm{E} \\
\text { (D-B) }\end{array}$ \\
$\begin{array}{c}\text { Real Interest } \\
\text { Rate }\end{array}$ & $\begin{array}{c}\text { Inflation } \\
\text { Rate }\end{array}$ & $\begin{array}{c}\text { Nominal Interest } \\
\text { Rate }\end{array}$ & $\begin{array}{c}\text { Tax Cost of } \\
\text { Borrowing }\end{array}$ & $\begin{array}{c}\text { Real After-Tax } \\
\text { Cost of } \\
\text { Borrowing }\end{array}$ \\
\hline 4 & 2 & 6 & 3 & 1 \\
4 & 4 & 8 & 4 & 0 \\
4 & 6 & 10 & 5 & -1 \\
4 & 8 & 12 & 6 & -3 \\
4 & 10 & 14 & 7 & -4 \\
4 & 12 & 16 & 8 & -3 \\
\hline
\end{tabular}

Turning to the creditor's side, the effects were the opposite: the real aftertax rate of return is inversely related to the rise in nominal interest rates so that the real after-tax rate of return declined. If the creditor's marginal tax rate is $50 \%$, Column $\mathrm{E}$ of Table 1 also shows the real after-tax return to the creditor at the various inflation rates.

Feldstein argues that negative real rates of interest on borrowing and negative real rates of return on investments had the following effects: (1) the fall in real after-tax rates of return likely contributed to the fall in the personal saving rate and the rise in consumer demand;15 (2) the fall in real after-tax rates of borrowing likely caused increased demand for residential investment and increased prices for housing and similarly encouraged the growth of consumer credit and the purchase of consumer durables; ${ }^{16}$ and (3) corporate benefits from lower real after-tax interest costs likely were more than offset by the 68.

14. M. FeldSTEIN, supra note 9, at 10; Feldstein, Inflation and the American Economy, supra note 7, at

15. M. Feldstein, supra note 9 , at 12 . However, as indicated in note 2, supra, the personal saving rate declined but total private saving in the United States remained very stable. Kotlikoff's calculations, supra note 2, indicate that net national saving has not been constant since 1950 .

16. Id. at 11. See generally id. at 81-98. The user cost of home ownership for taxpayers in all tax brackets is believed to have been substantially lowered during the 1960's and 1970's. Hendershott \& $\mathrm{Hu}$, Inflation and Extraordinary Returns on Owner-Occupied Housing: Some Implications for Capital Allocation and Productivity Growth, $3 \mathrm{~J}$. MAcroecon. 177 (1981). The user cost fell because the rise in general inflation rate raised current nominal interest rates, which are deductible, so that real after-tax rates of interest fell, and also raised the nominal increase in the price of houses which, however, is taxed (if at all) on a deferred basis as a capital gain. On the other hand, the cash-flow constraint of rising monthly mortgage payments due to increased inflation and interest rates acts as an offset to the 
lower real after-tax rate of return on investment (because of historic cost depreciation and inventory accounting rules). ${ }^{17}$

Thus, Feldstein concludes that the easy money-fiscal restraint mix did not lower interest costs and encourage capital accumulation, but had exactly the opposite effect. Because of the resulting inflation, nominal interest rates increased; but, taking into account the income tax rules, real after-tax interest costs and investment returns were lowered. These effects discouraged saving and misallocated savings to housing and consumer durables rather than to plant and equipment. This result in turn lowered productivity growth. ${ }^{18}$

Alternatively, Feldstein argued for the opposite policy mix-monetary restraint and fiscal ease-to achieve productivity growth. Monetary restraint, it is argued, lowers inflation and raises the real after-tax cost of borrowing. The higher interest rates will tend to dampen all forms of investment in the short-run, but this tendency will be more than offset by higher after-tax rates of return by lowering inflation, which will increase saving. ${ }^{19}$ Higher interest rates due to the tight monetary policy will especially dampen residential investment, and the increased savings due to higher after-tax rates of return can be directed into nonresidential investment by reducing the taxation of capital income from such investments. This mix of monetary-fiscal policy thus can shift the allocation of capital in favor of nonresidential investment.

The Reagan Administration and the Federal Reserve Bank have followed this policy. The Bank managed money tightly and ERTA reduced tax rates across the board and included some incentive provisions for saving, thereby attempting to increase the saving rate. Finally, it included tremendous nonresidential investment tax incentives to shift investment of savings away from housing and consumer durables and over to business assets.

Other economists question whether the supply of savings seriously contributed to decreased productivity growth. Second, they question whether

taxpayer's ability to exploit these tax advantages. Hendershott, in a 1980 study, measured separately the two effects and found that both were strong. Hendershott, Real User Costs and the Demand for Single-Family Housing, 1980 Brookings Papers on Econ. Activity 401. The effects partially offset each other, but because the price effect was stronger, inflation was a net stimulus to housing. Hendershott concluded that the reduction in real user cost between 1965 and 1980 shifted almost $0.5 \%$ of GNP into housing. Id. at 440-41; see B. Bosworth, supra note 2 , at 114 . For a discussion of housing investment, see B. BoswORTH, supra note 2, at 110-16.

17. M. Feldstein, Capital Taxation 44-53 (1983). See, however, the discussion infra, at text accompanying notes 75-77, of a study which concludes that overall marginal tax rates on income from capital in the nonfinancial corporate sector did not increase substantially as a result of inflation. See also B. BoswORTH, supra note 2, at 50-53, for a discussion of issues regarding measurement of effective tax rates on capital income.

18. For a discussion of econometric evidence that the interaction of inflation and certain tax provisions contributed substantially to the decline in business investment since the late 1960 's, see M. Feldstein, Inflation, Tax Rules and Investment: Some Economic Evidence (1980). Bosworth questions this conclusion. See B. Bosworth, supra note 2, at 51-53, 56.

19. Some economists think that this increase in private saving may be accompanied by greater government dissaving so that government expenditures must be reduced simultaneously. Other economists think that the supply of labor and capital is so sensitive to after-tax rates of return that, as a result of the tax cuts, such a substantial rise in private saving will occur that the taxes paid on the resulting increased income will cover the initial deficit produced by the tax cut. For a discussion of these views, see B. BosworTH, supra note 2, at 16-19. 
uncompensated tax reductions with respect to saving will in fact increase the supply of savings for private capital formation. Each of these questions is discussed below.

\section{What Caused the Decline in Productivity Growth?}

As outlined in the previous section, the explanation which dominated fiscal and monetary policy is a decline in nonresidential capital formation caused by decreasing real after-tax rates of return on such investment. Other economists question whether economic data support this conclusion. ${ }^{20}$ First, investment in nonresidential fixed capital as a percentage of GNP remained strong throughout the 1970's by historical standards. Table 2 summarizes these investment percentages. ${ }^{21}$ Blinder made the following comments about the relationship of business fixed investment as a percentage of GNP:

During the nine years from 1956 through 1964, when the inflation (GNP deflator) averaged only 2 percent, business fixed investment averaged 9 percent of GNP. During the eight years from 1965 through 1972, when the average inflation rate accelerated to 4.1 percent, the ratio of business fixed investment to GNP rose to 10.3 percent. During the high inflation years 1973-78, business fixed investment averaged 10 percent of GNP. Over the entire 1956-78 period, the simple correlation between inflation and the ratio of business fixed investment to GNP is positive $.53 .^{22}$

Table 2 and the comments by Blinder are based on gross investment as a percentage of GNP. Some economists have argued that capital is a source of productivity slowdown by emphasizing the relationship of net investment (the addition to the capital stock after deduction for depreciation of existing capital) as a share of GNP. ${ }^{23}$ Table 3, containing a summary of economic data compiled by Bosworth, ${ }^{24}$ shows (in the second set of data) that the present ratio of net investment to net output is low only in comparison to that of the

20. See, e.g., Jt. Comm. Print, supra note 7; Bosworth, supra note 2; Malkiel, supra note 4; Musgrave, Tax Policy and Capital Formation, 32 NAT'L TAX J. 351 (1979); Tobin, supra note 7.

21. Table 2 is derived from Tables B-1 and B-2 of Economic Report of The President 1984, supra note 1 , at $220,222$.

22. Discussion [of Taxation, Labor Supply, and Saving], 70 AM. Econ. REv., 187, 189-90 (comments by Alan Blinder) (1980). Pechman has provided the following figures on gross investment as a percentage of GNP:

TABLE 9

Nonresidential Fixed Investment as a Percent of GNP in Current and Constant Dollars

\begin{tabular}{lcc}
\hline Averages & Current (1979) & 1972 dollars \\
\hline $1955-64$ & 9.5 & 9.1 \\
$1965-74$ & 10.4 & 10.4 \\
$1975-79$ & 10.1 & 9.7 \\
\hline
\end{tabular}

Pechman notes that economists disagreed as to what portion of the ratio increase in the mid-1960's was due to a rise in demand and what portion to a reduction in the cost of capital. Pechman, Tax Policies for the 1980s, 11 TAX Notes 1195, 1196 (1980).

23. B. Bosworth, supra note 2 , at 23,38 n.27.

24. B. Bosworth, supra note 2, at 24; Bosworth, supra note 2, at 275. 
TABle 2

Nonresidential Fixed Investment as a Percentage of Gross

National Product in Current and Constant Dollars (1929 AND 1946-1979)

Percent of Gross National Product

\begin{tabular}{|c|c|c|}
\hline Year & Current dollars & 1972 dollars \\
\hline $\begin{array}{l}1929 \\
1946 \\
1947 \\
1948 \\
1949 \\
1950 \\
1951 \\
1952 \\
1953 \\
1954\end{array}$ & $\begin{array}{r}10.3 \\
8.1 \\
9.9 \\
10.1 \\
9.4 \\
9.5 \\
9.5 \\
9.0 \\
9.4 \\
9.3\end{array}$ & $\begin{array}{r}11.9 \\
8.8 \\
10.4 \\
10.4 \\
9.3 \\
9.3 \\
9.1 \\
8.7 \\
9.0 \\
9.0\end{array}$ \\
\hline $\begin{array}{l}1955 \\
1956 \\
1957 \\
1958 \\
1959 \\
1960 \\
1961 \\
1962 \\
1963 \\
1964\end{array}$ & $\begin{array}{r}9.6 \\
10.4 \\
10.6 \\
9.3 \\
9.4 \\
9.6 \\
9.1 \\
9.2 \\
9.2 \\
9.6\end{array}$ & $\begin{array}{l}9.3 \\
9.7 \\
9.7 \\
8.7 \\
8.8 \\
9.1 \\
8.8 \\
9.0 \\
9.0 \\
9.4\end{array}$ \\
\hline $\begin{array}{l}1965 \\
1966 \\
1967 \\
1968 \\
1969 \\
1970 \\
1971 \\
1972 \\
1973 \\
1974\end{array}$ & $\begin{array}{l}10.5 \\
11.0 \\
10.5 \\
10.4 \\
10.7 \\
10.5 \\
10.0 \\
10.2 \\
10.8 \\
10.9\end{array}$ & $\begin{array}{l}10.5 \\
11.0 \\
10.4 \\
10.3 \\
10.7 \\
10.5 \\
10.0 \\
10.2 \\
11.0 \\
10.9\end{array}$ \\
\hline $\begin{array}{l}1975 \\
1976 \\
1977 \\
1978 \\
1979 \\
1980 \\
1981 \\
1982 \\
1983\end{array}$ & $\begin{array}{l}10.2 \\
10.1 \\
10.7 \\
11.5 \\
12.0 \\
11.7 \\
11.9 \\
11.3 \\
10.5\end{array}$ & $\begin{array}{r}9.7 \\
9.7 \\
10.2 \\
11.0 \\
11.5 \\
11.2 \\
11.5 \\
11.2 \\
10.9\end{array}$ \\
\hline $\begin{array}{l}\text { Iverages } \\
947-54 \\
955-64 \\
965-74 \\
975-79 \\
980-83\end{array}$ & $\begin{array}{r}9.5 \\
9.6 \\
10.5 \\
10.9 \\
11.3\end{array}$ & $\begin{array}{r}9.4 \\
9.2 \\
10.6 \\
10.4 \\
11.2\end{array}$ \\
\hline
\end{tabular}


years 1966-70. Moreover, recent decreases in net investment as a percentage of net capital stock can be explained by a shift in the mix of investment to shorter-lived assets. ${ }^{25}$

TABLE 3

Alternative Measures of the Trend in Capital Formation of Domestic Nonresidential Business Sector, Selected Periods, 1951-1980a

\begin{tabular}{|c|c|c|c|c|c|c|}
\hline Measure & 1951-55 & 1956-60 & $1961-65$ & $1966-70$ & $1971-75$ & $1976-80$ \\
\hline \multicolumn{7}{|l|}{$\begin{array}{l}\text { Gross fixed nonresidential } \\
\text { investment as a percent } \\
\text { of gross output }\end{array}$} \\
\hline $\begin{array}{l}\text { Current dollars } \\
\text { Constant dollars }\end{array}$ & $\begin{array}{l}11.4 \\
11.7\end{array}$ & $\begin{array}{l}12.2 \\
22.9\end{array}$ & $\begin{array}{l}12.1 \\
23.4\end{array}$ & $\begin{array}{l}13.6 \\
13.9\end{array}$ & $\begin{array}{l}13.7 \\
13.6\end{array}$ & $\begin{array}{l}14.6 \\
14.5\end{array}$ \\
\hline \multicolumn{7}{|l|}{$\begin{array}{l}\text { Net fixed nonresidential } \\
\text { investment as a percent } \\
\text { of net output }\end{array}$} \\
\hline $\begin{array}{l}\text { Current dollars } \\
\text { Constant dollars }\end{array}$ & $\begin{array}{l}3.8 \\
3.9\end{array}$ & $\begin{array}{l}3.5 \\
3.5\end{array}$ & $\begin{array}{l}4.0 \\
4.2\end{array}$ & $\begin{array}{l}5.6 \\
5.8\end{array}$ & $\begin{array}{l}4.4 \\
4.5\end{array}$ & $\begin{array}{l}4.3 \\
4.3\end{array}$ \\
\hline $\begin{array}{l}\text { Net fixed nonresidential } \\
\text { investment as a percent } \\
\text { of net capital stockb }\end{array}$ & 4.1 & 3.5 & 4.2 & 5.7 & 4.0 & 3.8 \\
\hline \multicolumn{7}{|l|}{$\begin{array}{l}\text { Percentage change in the } \\
\text { ratio of net capital stock } \\
\text { to total business hours }\end{array}$} \\
\hline $\begin{array}{l}\text { Actual } \\
\text { Cyclically adjusted }\end{array}$ & $\begin{array}{l}3.3 \\
3.4\end{array}$ & $\begin{array}{l}3.5 \\
3.1\end{array}$ & $\begin{array}{l}2.9 \\
4.0\end{array}$ & $\begin{array}{l}4.3 \\
3.9\end{array}$ & $\begin{array}{l}3.2 \\
2.8\end{array}$ & $\begin{array}{l}0.6 \\
1.3\end{array}$ \\
\hline $\begin{array}{l}\text { Ratio of net capital stock } \\
\text { to gross outputb }\end{array}$ & 1.26 & 1.32 & 1.29 & 1.29 & 1.39 & 1.4 \\
\hline
\end{tabular}

Source: National income and product accounts and the U.S. Bureau of Labor Statistics.

a. Private business sector, excluding housing.

b. Both nonresidential stock of equipment and structures and output valued in 1972 dollars.

c. The cyclically adjusted series was derived from a regression of the change in the ratio of capital to man-hours on a time trend, the change in real GNP, and the utilization of potential GNP. The series represents the ratio adjusted for departures of GNP from potential.

Many have argued that capital formation appears weak when measured against the large increases in labor outputs during the 1970's which caused a slowdown in the annual growth in the ratio of net capital stock to total hours worked. The ratio of capital to labor is shown in the fourth set of data in Bosworth's Table 3. Bosworth investigated the relative contributions of labor and capital to total productivity and concluded that the slowdown in the growth of capital relative to labor inputs had only a negligible effect on productivity growth. Other economists have agreed. ${ }^{26}$

25. B. Bosworth, supra note 2 , at 38 n.27, 64 .

26. For example, Denison attributes to the slower increase in capital per worker only $0.12 \%$ of the 3\% decrease in the growth rate in national income per person employed during 1973-76. Denison, Explanations of Declining Productivity Growth, 59 SURv. CURRENT Bus. 1 (1979). McCarthy 
Table 4 provides a summary made by Bosworth of the estimated effect of various factors contributing to productivity slowdown. ${ }^{27}$ This table shows that the rate of growth of labor productivity between 1948-67 and 1973-80 had slowed by $2.1 \%$. However, only approximately 0.15 of the $2.1 \%$ slowdown is attributable to a reduced rate of growth in capital labor ratios. Bosworth has also noted that the before-tax rate of return to capital investment declined from $11.2 \%$ in 1967 to $8.2 \%$ in $1980 .{ }^{28}$ This decline conflicts with "the common assertion that capital formation was insufficient" during the 1970 's, since too small a supply of capital should ordinarily yield higher before-tax rates of return. ${ }^{29}$

TABLE 4

Estimates of Sources of the Productivity Slowdown in the Nonfarm NonRESIDENTIAL Business Economya

\begin{tabular}{lc}
\hline Source & $\begin{array}{c}\text { Average annual } \\
\text { percentage change }\end{array}$ \\
\hline
\end{tabular}

\begin{tabular}{lr} 
Factors contributing to the slowdown & \\
Capital-labor substitution & $0.1-0.2$ \\
Labor quality & $0.1-0.2$ \\
Regulation & $0.2-0.3$ \\
Research and development & $0.1-0.3$ \\
Energy & $0.1-0.2$ \\
Sectoral shifts & $0.0-0.1$ \\
Residual & $1.0-0.5$ \\
Total decline in trend growth & 1.6 \\
Cyclical influence & 0.5 \\
Total decline in labor productivity growth & 2.1 \\
\hline
\end{tabular}

a. The slowdown is defined as the difference in the average annual growth of labor productivity between 1948-67 (2.6\%) and 1973-80 (0.5\%).

estimates that $\mathbf{0 . 7 - 0 . 8 \%}$ of the reduction in productivity growth was due to the slow growth in the capital/labor ratio. McCarthy, The U.S. Productivity Growth Recession: History and Prospects for the Future, 33 J. Fin. 977 (1978). By contrast, Musgrave estimated that the drop in the rate of increase of the capital/labor ratio accounted for one-third of the decline in productivity growth. Musgrave, supra note 20, at 35l. The Reagan Administration appears to attribute a substantial part of the productivity slowdown to the decline in growth of the capital/labor ratio. See Impact of the Tax System on Productivity and Economic Growth: Hearing before the Subcomm. on Oversight of the Internal Revenue Service of the Comm. on Senate Finance, 98th Cong., 2d. Sess. 44, 46-47, 50 (1984) (statement of Charles E. McLure, Jr., Deputy Assistant Secretary of the Treasury for Tax Analysis).

27. Table 4 summarizes Bosworth's own investigation as well as various other studies which are discussed in B. Bosworth, supra note 2, at 28-44. For example, Denison and McCarthy have attributed the largest portion of the decline to nonmeasurable residual factors that contribute to productivity growth, which include advances in knowledge. Denison, supra note 26; McCarthy, supra note 26. Thurow has attributed the slowdown to a shift in economic activity from high productive to low productive industries such as service industries. Thurow, The U.S. Productivity Problem, Data Resources U.S. Rev. 1.14 (August 1979); see also Summers, Comments and Discussion [of Bosworth, supra note 2], 1982 Brookings Papers on Econ. Activity 322. The Reagan Administration has provided a summary of the various factors that may have contributed to the slowdown in productivity growth, without attempting to quantify the effects of the various factors. See Impact of the Tax System on Productivity and Economic Growth, supra note 26, at 47-50.

28. B. Bosworth, supra note 2, at 53.

29. See id. at 56-57. 
This section presents a brief survey of the debate. What clearly emerges from a reading of the literature, however, is that within their own profession, economists differ on the critical issue whether the rate of capital formation has really been too slow during the last decade and, if so, whether it has contributed much to productivity slowdown. Based on a review of economic data and studies, Bosworth concludes that economists cannot explain why the slowdown in productivity growth occurred, and that the argument linking reduced capital formation to slowdown has not been proved. ${ }^{30}$

If Bosworth's recent analysis of the literature stands, it raises substantial doubts about the adequacy of the justification for the 1981 tax changes, since as explained in the previous section, they were largely based on the link between after-tax rates of return to capital, the rate of capital formation, and slowdown in productivity growth. This justification is questioned further by Bosworth in a study, discussed below in Section II(B), which investigates the causes and composition of increased investment in 1983-84. He finds no correlation between the growth in specific categories of assets and the relative magnitude of reduction in effective tax rates for specific assets.

\section{Is the Level of Saving Sensitive to Tax Rates?}

Assuming that the political decision were made that the United States ought to save more, can the rate of private saving be increased by lowering the rate of tax on income from saving? The argument is made that such a decrease will produce increased saving; accordingly, several parts of Reagan's 1981 tax program included provisions to decrease the tax rate imposed on saving. Theoretically, this hypothesis is difficult to prove because of offsetting income and substitution effects. If after-tax rates of return are increased through reduction of tax on capital income, the result may be a substitution effect: a reduction of consumption and an increase in saving, as people take advantage of the higher after-tax rates of return. Alternatively, the increase in income from savings relative to previously planned income may entice individuals to increase the proportion of income spent on their consumption, so that reduction in the taxation of capital income will have little impact on capital formation. Also, if tax reductions are used to encourage private saving, and if the government does not reduce its expenditures by an amount equivalent in effect to the tax reductions, the private sector must save all of these reductions to leave the national saving rate unchanged. How likely is this to occur?

Empirical studies to date are inconclusive about the dominance of the income or substitution effect. ${ }^{31}$ One economist has measured the interest

30. See id. at 56-58.

31. See, e.g., B. Bosworth, supra note 2, at 79 ("It is readily apparent from a review of empirical studies that no consensus has emerged with respect to the effect of interest rates on savings."); Blinder, supra note 22, at 190 ("No one can confidently claim that a strong saving response to higher interest rates is well established."); Bosworth, supra note 2, at 309 ("The empirical issue of sensitivity of saving decisions to rates of return has not been resolved."). For good summaries of the status of research and the debate, see Boskin \& Shoven, Issues in the Taxation of Capital Income in the United States. 
elasticity of private saving with respect to the real after-tax rate of return on savings to be 0.4 (i.e., a $10 \%$ increase in the real after-tax rate of return would cause a $4 \%$ increase in savings); ${ }^{32}$ others have measured the elasticity to be around zero. ${ }^{33}$

Those who conclude or assume that the interest elasticity of saving is positive argue that reducing the tax rate on capital income should be a top priority in tax reform. Because of the uncertain interest elasticity of private saving, and because total gross private savings (by households and business firms) have been so constant a percentage of GNP, ${ }^{34}$ many economists have noted, however, that creating savings through government surpluses (or reduced deficits) in periods of high employment may be preferable to trying to increase the saving rate in the United States through tax incentives. ${ }^{35}$ Tobin, for example, has stated:

The supply-side notion that uncompensated tax concessions to saving will increase the national supply of saving for private capital formation, as a fraction of GNP, is dubious. The fatal flaw is that such concessions are likely to lose more public saving than the private saving they promote unless the rate-of-return elasticity of saving (saving as a whole, not particularly favored assets) is much greater than any credible estimates. ${ }^{36}$

Even if the interest elasticity of private saving is positive, so that the Reagan Administration's policy of monetary restraint and fiscal ease does increase private savings, those savings will not be largely available for private investment if the government continues to run deficits and has to borrow to finance government expenditures. ${ }^{37}$ The 1981 tax reductions were implemented without any concurrent agreement with respect to government expenditure reductions, and this failure on the expenditure side continues to threaten the political future of the Reagan Administration's fiscal policies. Also, the focus on domestic saving ignores the openness of our capital markets with respect to both import and export of capital. International capital flows reduce the impact of the rate of domestic saving as a constraining

70 Am. Econ. Rev. 164 (1980); Kotlikoff, supra note 2, at 1594-96; Von Furstenberg \& Malkiel, The Government and Capital Formation: A Survey of Recent Issues, 15 J. Econ. LrT. 835, 838-43 (1977).

Economists, using optimal tax theory, have concluded that interest elasticity of saving is not very significant in determining the most efficient tax structure. See, e.g., Bradford, The Economics of Tax Policy Toward Savings, in The Government and Capital Formation 11 (G. Von Furstenberg ed. 1980); King, Savings and Taxation, (NBER Working Paper No. 428, 1980).

32. Boskin, Taxation, Saving, and the Rate of Interest, $86 \mathrm{~J}$. PoL. Econ. S3 (April 1978).

33. E.g., Howrey \& Hymans, The Measurement and Determination of Loanable Funds Saving, 1978 Brookings Papers on Econ. Activity 655. For a discussion of the studies by Boskin and by Howrey and Hymans, see B. BosworTH, supra note 2, at 79-80; Kotlikoff, supra note 2, at 1594-95.

34. Since 1951 , total private savings as a share of GNP has been $16-17 \%$. Composition of private savings has varied. See B. Bosworth, supra note 2, at 62-63; supra note 2. Kotlikoff's calculations show, however, that net private saving (taking into account depreciation) has been far from constant. See supra note 2.

35. Jt. Comm. Print., supra note 7, at 8; B. Bosworth, supra note 2, at 96; Von Furstenberg \& Malkiel, supra note 31, at 843; see also Bradford, supra note 31, at 29, 34, 61; Feldstein, supra note 5, at 120. Some economists have argued, however, that variations in government saving have no effect on national saving because the level of private saving adjusts to offset changes in government saving. For a discussion of these arguments, see B. BoswORTH, supra note 2, at 86-89.

36. Tobin, supra note 7 , at 40.

37. See Bosworth, supra note 2, at 309-10. 
influence on the rate of domestic investment, and the presence of such flows suggests that an increase in domestic saving would not be fully reflected in domestic investment. Because of these various considerations, some economists accordingly question whether incentives to increase private saving rates can have any substantial effect on the level of domestic savings and capital investment. ${ }^{38}$

Tanzi and Sheshinski reviewed available saving rate statistics for the period 1970 through the second quarter of 1984 and determined that the United States personal saving rate, viewed alone or in combination with undistributed corporate profits, showed no important increase after the enactment of ERTA and during Reagan's first Administration. ${ }^{39}$ An explanation for this result possibly may be that the income effect of the increased real after-tax rate of return to saving dominated the substitution effect because retired persons hold a substantial amount of total financial assets. Thus, the increase in the rate of return disproportionately increased the income of those persons likely to spend more and save less of their higher income, relative to the rest of the population. ${ }^{40}$

\section{E. Implications for Tax Policy}

Although capital formation is an important factor in productivity growth, this survey of economic literature reveals differences in opinion on the extent to which levels of nonresidential fixed investment contributed to declining productivity growth in the 1970's. Opinions also differ on the role played by the income tax system in determining aggregate levels of saving. Feldstein and other economists have argued that the interaction of inflation with an unindexed income tax base caused increased tax burdens on capital income and thereby lowered savings and capital investment. Other economists note the uncertain interest elasticity of private saving and the constancy of the rate of total private saving relative to GNP, and are doubtful about the linkage of aggregate capital formation to after-tax rates of returns.

Importantly, recent studies have also concluded that the actual overall effective tax rates on return to capital are largely invariant with changes in the inflation rate. This conclusion, discussed in more detail in the next part of the paper, conflicts with the earlier argument by Feldstein and others that

38. For a summary of the findings of various studies about the role of international capital flows, see, for example, B. Bosworth, supra note 2, at 125-27. Notwithstanding these doubts, some economic studies have estimated efficiency gains based on a positive interest elasticity of saving. These studies included estimates of efficiency gains resulting from a switch to a consumption tax (zero tax rate on savings). See, e.g., Fullerton, Shoven \& Walley, Replacing the U.S. Income Tax with a Progressive Consumption Tax: A Sequenced General Equilibrium Approach (NBER Working Paper No. 892, 1982); Summers, Tax Policy in a Life Cycle Model (NBER Working Paper No. 302, 1978). Fullerton, Shoven and Walley determined that the net gains after the transition period from the current tax system to the progressive consumption tax would be $\$ 650$ billion (computed as a present value in 1973 dollars), just over $1 \%$ of the discounted present value of national income.

39. Tanzi \& Sheshinski, Fund Study Suggests Answer to the U.S. Savings Puzzle, 13 IMF SuRVEY 353 (1984).

40. Id. at $366-67$. 
significant increases in overall effective tax rates resulted from the interaction of the tax system and inflation. Thus, much of the economic basis for the Reagan Administration's tax program to increase saving, investment, and productivity growth has been substantially questioned and challenged by many economists.

Nevertheless, a broad consensus exists with respect to several factors about capital formation. First, increased levels of capital formation are desirable, even though disagreement exists over the most appropriate methods to achieve larger aggregate savings. ${ }^{41}$ Second, whatever policies yield higher productivity growth, the amount of increase will be modest and returns in added consumption long delayed. Pechman estimates that a one percent increase in the ratio of investment to GNP will generate a $0.2 \%$ increase in the annual rate of productivity growth. ${ }^{42}$ Thus, if taxes were reduced by $1 \%$ of GNP and all tax reductions were saved, the impact on growth rates of productivity would be far from spectacular. Other economists agree. $^{43}$

Third, whatever the uncertainty about the impact of higher after-tax rates of return on the saving rate, empirical studies indicate that lowering the cost of capital through tax incentives will have a positive effect on the level of capital investment. The magnitude of response is uncertain, but the propensity to invest is thought to be as high as unity for new equipment: that is, the amount of investment in new equipment induced by the tax incentive will equal the lost tax revenues. ${ }^{44}$ Econometric studies also show that the response to lower cost of capital is more substantial for residential structures and consumer durables than for business investment. ${ }^{45}$ Thus, tax incentives can be used to increase demand for business investment, but to accomplish increased business capital formation these incentives may need to be targeted at business capital since investment in such capital is thought to be less responsive to the incentives than other types of investments.

Fourth, economists also are very likely to agree that whatever the effect on aggregate levels of capital formation, the present system of investment and saving incentives and the interaction of inflation and an unindexed income tax base cause inefficiencies in capital allocation. ${ }^{46}$ Marginal tax rates on different types of capital income vary according to varying lengths of lives of capital assets and differing tax treatment of different forms of investment such as corporate or noncorporate, debt or equity, residential or nonresidential.

41. See supra text accompanying note 4 .

42. Pechman, supra note 22, at 1196.

43. See, e.g., B. Bosworth, supra note 2, at 45, 58; Bosworth, supra note 2, at 308; Tobin, supra note 7, at 37-38; General Discussion [of Tobin, supra note 7], 1980 Brookings Papers on Econ. ACTIVITY 86. Bosworth also explains that a rise in the saving rate shifts the economy to a higher level of output, but once the transition is complete after several years, the rate of growth is unaffected. B. BoswORTH, supra note 2, at 44-47.

44. See B. Bosworth, supra note 2, at 106-10.

45. Id. at 184; see id. at 125 .

46. See, e.g., M. King \& D. Fullerton, supra note 12, at 243-57, 308; Feldstein, Inflation and the American Economy, supra note 7, at 73; Tobin, supra note 7, at $39-40$. 
These variances in tax rates, in turn, create capital misallocation. Thus, if the income tax were designed to be more neutral with respect to type of capital investment and more inflation neutral, productivity gains would result from increased efficiency in allocation of capital regardless of whether the aggregate level of capital were increased.

The Reagan Administration used a linkage of inflation and overtaxation of capital income as the justification for its 1981 tax program. ${ }^{47}$ However, the Administration's major proposals (which were all enacted) were curiously lacking in direct responses to this inflation effect. Tobin has spoken disparagingly of this omission:

Economists know that stabilization policy is logically and operationally separable from the size and balance of the budget. The demand stimulus of a larger budget can be neutralized by various mixtures of taxation and monetary restriction, and the demand stimulus of a deficit-increasing tax reduction can be offset by monetary restriction. What is occurring today is a concerted campaign to exploit the popular discontent with inflation to reduce the relative size of the public sector and to reverse the income redistributions effected by government taxes and transfers. These objectives are legitimate political agenda, which deserve debate and decision on their merits. But they have nothing to do with inflation . . . 48

Tobin's charge with respect to the equity issue of income redistribution is recognized by other economists. ${ }^{49}$ Since capital is concentrated in the hands of the wealthiest taxpayers, use of the tax system to increase aggregate levels of capital formation by uncompensated reductions in the effective rates of tax on capital income will make the income tax less progressive. Nevertheless, in recent legislation this equity concern yielded to the efficiency concern for stimulation of productivity growth.

The next section of this paper discusses the provisions of ERTA and subsequent legislation designed to increase levels of nonresidential capital investment and explores the interaction of these provisions with the choice of debt versus equity financing, with changes in inflation rates, and with other factors that influence the effective tax rates on capital income. It discusses in substantial detail the variance in marginal effective tax rates on capital income under the current income tax system. It also discusses whether increased capital investment in 1983-84 is linked to ERTA.

II

\section{EfFiciency Under ERTA and Subsequent Tax Legislation}

The Economic Recovery Tax Act (ERTA) ${ }^{50}$ reflects the Reagan Administration's tax policy described in the preceding section. First, it reduced individual tax rates by $23 \%$ by $1983,{ }^{51}$ reduced the maximum rate on unearned income from $70 \%$ to $50 \%$ so that the maximum rate on all income

47. See supra note 6 .

48. Tobin, supra note 7 , at 57 .

49. See, e.g., B. Bosworth, supra note 2, at 21; Musgrave, supra note 20, at 353-54.

50. Pub. L. No. 97-34, 95 Stat. 172 (1981).

51. Id. $\$ 101(\mathrm{a}), 95$ Stat. at 176 . 
is $50 \%, 52$ and included an indexation system of rates, exemptions, and zero bracket amounts effective in 1985.53 All of these changes were reactions to the bracket creep caused by inflation in the immediate past and reflect a capital formation policy which assumes that levels of aggregate saving are sensitive to after-tax rates of return. ${ }^{54}$ Second, ERTA liberalized retirement plan provisions to allow larger deductible contributions, thereby also providing tax incentives to increase savings. ${ }^{55}$ Third, ERTA substantially increased business investment incentives by introducing a new depreciation system called the Accelerated Cost Recovery System (ACRS), liberalizing the investment tax credit, and creating so-called "safe-harbor" leasing. These incentives were designed to channel the increased savings from tax reductions into business investment. The demand for such investment would be increased by lowering its after-tax cost.

Under ACRS, business assets are assigned tax lives shorter than actual length of economic utility: either three or five years for most equipment and fifteen years for structures. ${ }^{56}$ Accelerated depreciation methods are permitted, and for tangible personal property even faster depreciation would have been allowed under ERTA for years 1985 and later. ${ }^{57}$ In keeping with the goal of promoting domestic business investment, these incentives were not applied to business assets used outside the United States. ${ }^{58}$ The safeharbor leasing provisions recognized that some businesses, such as new businesses or those without any taxable income, would not be able to use entirely or in part the increased depreciation deductions and investment tax credits. Such tax benefits have been transferred from such taxpayers to other taxpayers with sufficient income to absorb these benefits by leasing transactions. ERTA created a safe harbor to guarantee that certain transactions would be treated as leases and therefore transfer successfully the tax benefits. ${ }^{59}$

52. Id.

53. Id. § 104(b), (c), 95 Stat. at 189.

54. See S. REP. No. 144, 97th Cong., 1st Sess. 11-12, 23-25 (1981); Impact of the Tax System on Productivity and Economic Growth, supra note 26, at 51-53.

55. Pub. L. No. 97-34, $\S 311-312,95$ Stat. at 274-85. ERTA also permitted the exclusion of interest income on certain one-year savings certificates issued after September 30, 1981, and before January 1, 1983. Id. $\S 301,95$ Stat. at 267-70. ERTA also provided for the exclusion of $15 \%$ of net interest up to $\$ 3,000$ ( $\$ 6,000$ on a joint return) of net interest received, for tax years beginning in 1985. Id. $\$ 302$, 95 Stat. at $270-74$. This interest income exclusion was repealed by $\$ 16$ of the Tax Reform Act of 1984. Pub. L. No. 98-369, \& 16, 98 Stat. 494, 505 (1984).

56. I.R.C. \& 168 (Lawyers Co-op. Supp. 1985).

57. ERTA allowed the following methods of cost recovery for personal property:

$\begin{array}{ll}\text { Years } & \text { Method } \\ 1981-84 & 150 \% \text { declining balance switching to straight line } \\ 1985 & 150 \% \text { declining balance switching to sum-of-the-years' digits } \\ \text { After } 1985 & 200 \% \text { declining balance switching to sum-of-the-years' digits }\end{array}$

As discussed infra in text accompanying note 61 , the increased depreciation rates for personal property in 1985 and subsequent years were repealed in 1982 . Structures are allowed a method approximating $175 \%$ declining balance. Pub. L. No. 97-34, 8201,95 Stat. at 203-19.

58. See id.

59. See id. 
The Reagan Administration may have planned expenditure cuts to match the lost revenues produced by ERTA. This failed to materialize, and the 1981-82 recession contributed further to the mismatch of revenue and expenditures. The projected deficit plus the criticism that the business investment incentives in ERTA were too generous (particularly at lower inflation rates) compelled Congress in 1982 to enact the Tax Equity and Fiscal Responsibility Act of 1982 (TEFRA) ${ }^{60}$ to reduce them. In particular, it repealed the additional accelerated depreciation allowances scheduled for 1985 and later, ${ }^{61}$ required an adjustment in an asset's depreciation base for $50 \%$ of the tax value of the investment tax credit, ${ }^{62}$ and eliminated safeharbor leasing by $1983 .{ }^{63}$ In the Tax Reform Act of 1984, Congress reacted to criticism that the recovery period for buildings was too short by extending the period from fifteen to eighteen years, except for low-income housing which remains fifteen years. ${ }^{64}$

What are the economic effects of ERTA and TEFRA? The most extensive economic research concerns their impact on effective tax rates on capital income and on the resulting capital allocation. ${ }^{65}$ Recent research has also

60. Pub. L. No. $97-248,96$ Stat. 324.

61. Id. § 206, 96 Stat. at 431 .

62. Id. $\$ 205,96$ Stat. at $427-31$. For example, if an asset cost $\$ 10,000$ and the investment tax credit were $\$ 1,000$ (10\% of the cost), the depreciation base of $\$ 10,000$ is reduced by $\$ 500(50 \%$ times $\$ 1,000$ credit) to $\$ 9,500$. Alternatively, the taxpayer may take an investment tax credit of $\$ 800$ $(8 \%$ of the cost), and then is not required to reduce the depreciation base.

63. Id. $\S \S 208,209,96$ Stat. at $432-47$.

64. Pub. L. No. 98-369, § 111,98 Stat. 494, 631-34.

65. For an extensive discussion of effective tax rates and their capital allocation effects since World War II and prior to ERTA, see Jorgenson \& Sullivan, Inflation and Corporate Capital Recovery, in Depreciation, Inflation, and the Taxation of Income from Capital 171 (C. Hulten ed. 1981). The article includes the following calculations:

(1) Table 9 at 193 compares replacement cost economic depreciation with tax depreciation ("actual corporate capital consumption allowances") for years 1946-1978. For the years 1962-1973, tax depreciation exceeded replacement cost economic depreciation, but for 1974-1978, the reverse was true.

(2) Table 11 at 196 compares the statutory corporate tax rate with effective corporate tax rates for equipment, structures, and the two combined. For all post-war years, effective tax rates were less than statutory tax rates. For example, in 1980, the statutory corporate tax rate was $46 \%$, but the effective tax rates for structures, equipment, and their aggregate were $35.2 \%, 18.5 \%$, and $24.3 \%$, respectively.

(3) Table 12 at 199-201 illustrates the variance of effective tax rates among different kinds of assets. For example, in 1979, the range of effective tax rates extended from zero (for airplanes) to $46 \%$ (for nonfarm buildings).

(4) Tables 13 and 14 at 203-09 show the variance of effective tax rates among industries. For example, in 1979 the range of effective tax rates measured $30 \%$ (from zero for air transportation to $30 \%$ for metal mining and utilities).

Jorgenson and Sullivan summarize their findings as follows:

Our analysis of differences in effective tax rates among types of assets and among industries reveals larger differences than those between equipment and structures for all U.S. corporations. Differences between effective tax rates correspond to gaps between social rates of return among assets and industries. These gaps present opportunities for costless increases in the national wealth that would be available for consumption or additional investment. The gaps are very large, indicating that there is a substantial loss in efficiency in the allocation of capital under U.S. tax law. It is important to reiterate that differences in effective tax rates among assets and industries would increase with a decrease in the rate of inflation.

Id. at $\mathbf{2 1 0}$. 
tried to determine whether increased capital investment resulted from the legislation. Section A examines the legislation's effect on capital allocation, and section $B$ discusses recent research by Bosworth concerning whether increased capital investment in 1983-84 is attributable to the tax legislation.

\section{A. Capital Allocation Effect of ERTA and TEFRA}

This legislation substantially reduced the tax rate on most types of new, depreciable business investment, but in varying amounts. Taxes which apply different effective rates to alternative new investments can cause inefficiencies in resource allocation. These distortions may be magnified by changes in the inflation rate if the tax system is not indexed for inflation. Under ACRS, as created by ERTA and TEFRA, the value of the depreciation allowances varies among assets because assets of varying economic depreciation rates have been grouped together in too few asset classes, so that the allowances are unlikely to have a strong correlation to economic depreciation. Moreover, the allowances are not indexed for inflation. ERTA and TEFRA accordingly have produced varying effective tax rates on income from different assets and industries and the variance of these rates changes unevenly with changes in the rate of inflation.

These various effects have been quantified by several economists. Table 5 , prepared by Auerbach, ${ }^{66}$ shows the present value of ACRS allowances and investment tax credits, discounted at an after-tax rate of $12 \%$, for assets in the three-, five-, and fifteen-year classes.

Significantly, the present value of the allowances for one dollar of investment in three-year and five-year property is greater than one dollar. An investment incentive indeed! This subsidy is better than allowing an immediate deduction for the investment. Such a deduction yields a zero effective tax rate. ${ }^{67}$ These values would have increased in 1985 and 1986 because of the faster accelerated depreciation allowances in ERTA. As noted earlier, however, TEFRA repealed these increases. Also, as noted earlier, TEFRA lowered the value of the investment tax credit, so that today only the figures in the first column would be applicable, and for three- and five-year property they would be closer to one in value since they do not reflect the change in, the investment tax credit. ${ }^{68}$ Moreover, the Tax Reform Act of 1984 lengthened the recovery period for most real property from fifteen to

66. Auerbach, The New Economics of Accelerated Depreciation, 23 B.C.L. REv. 1327, 1346-48 (Tables 5 and 6) (1982).

67. The equivalence of deducting an investment immediately to imposing a tax on the initial receipt of the funds used to make the investment and then exempting from tax the income from the investment was shown in an article by Brown. Brown, Business-Income Taxation and Investment Incentives, in Income, Employment and Public Policy 300 (1948).

68. Elimination of negative effective tax rates was a primary reason for the cutbacks by TEFRA in both the rates of accelerated depreciation and the value of the investment tax credit. 1 S. REP. No. 494, 97th Cong., 2nd Sess. 122-23, 126 (1982). Negative tax rates also create intertemporal inefficiencies because of distortions between present and future consumption which cannot be justified, as positive tax rates may be, on the need to raise government revenues to produce public goods. 
TABLE 6

\author{
Marginal Total Effective Tax Rates \\ (Based on Real Pre-tax Rate of Return of 10\%)
}

\begin{tabular}{|c|c|c|c|c|c|c|c|c|c|}
\hline & \multicolumn{9}{|c|}{ Inflation Rate } \\
\hline & \multicolumn{3}{|c|}{ Zero } & \multicolumn{3}{|c|}{$10 \%$} & \multicolumn{3}{|c|}{ Actual $6.77 \%$} \\
\hline & 1980 & $\begin{array}{c}\text { ERTA } \\
1981 \\
\end{array}$ & $\begin{array}{c}\text { TEFRA } \\
1982 \\
\end{array}$ & 1980 & $\begin{array}{c}\text { ERTA } \\
1981 \\
\end{array}$ & $\begin{array}{c}\text { TEFRA } \\
1982 \\
\end{array}$ & 1980 & $\begin{array}{c}\text { ERTA } \\
1981 \\
\end{array}$ & $\begin{array}{c}\text { TEFRA } \\
1982 \\
\end{array}$ \\
\hline $\begin{array}{l}\text { Asset } \\
\text { Machinery } \\
\text { Buildings } \\
\text { Inventories }\end{array}$ & $\begin{array}{r}3.9 \\
35.4 \\
50.9\end{array}$ & $\begin{array}{r}-16.1 \\
24.1 \\
50.9\end{array}$ & $\begin{array}{r}-0.3 \\
27.4 \\
50.9\end{array}$ & $\begin{array}{l}22.8 \\
41.8 \\
45.5\end{array}$ & $\begin{array}{l}-0.9 \\
81.8 \\
45.5\end{array}$ & $\begin{array}{l}15.7 \\
34.7 \\
45.5\end{array}$ & $\begin{array}{l}17.6 \\
41.1 \\
47.0\end{array}$ & $\begin{array}{r}-5.5 \\
30.2 \\
47.0\end{array}$ & $\begin{array}{l}11.0 \\
33.2 \\
47.0\end{array}$ \\
\hline $\begin{array}{l}\text { Industry } \\
\text { Manufacturing } \\
\text { Other industry } \\
\text { Commerce }\end{array}$ & $\begin{array}{l}44.2 \\
10.0 \\
37.9\end{array}$ & $\begin{array}{r}35.7 \\
-2.9 \\
26.7\end{array}$ & $\begin{array}{r}38.4 \\
7.9 \\
29.6\end{array}$ & $\begin{array}{l}55.0 \\
15.8 \\
37.5\end{array}$ & $\begin{array}{r}46.0 \\
2.0 \\
27.5\end{array}$ & $\begin{array}{l}49.0 \\
12.4 \\
30.5\end{array}$ & $\begin{array}{l}52.7 \\
14.6 \\
38.2\end{array}$ & $\begin{array}{r}43.5 \\
0.7 \\
27.5\end{array}$ & $\begin{array}{l}46.4 \\
11.4 \\
30.5\end{array}$ \\
\hline $\begin{array}{l}\text { Source of Finance } \\
\text { Debt } \\
\text { New issues } \\
\text { Ret'd earnings }\end{array}$ & $\begin{array}{r}-2.0 \\
61.0 \\
48.4\end{array}$ & $\begin{array}{r}-17.6 \\
55.1 \\
40.2\end{array}$ & $\begin{array}{r}-8.9 \\
57.8 \\
43.9\end{array}$ & $\begin{array}{r}-22.2 \\
104.6 \\
66.5\end{array}$ & $\begin{array}{r}-37.1 \\
98.4 \\
57.7\end{array}$ & $\begin{array}{r}-29.1 \\
101.2 \\
61.7\end{array}$ & $\begin{array}{r}-16.3 \\
91.2 \\
62.4\end{array}$ & $\begin{array}{r}-31.9 \\
84.9 \\
53.4\end{array}$ & $\begin{array}{r}-23.5 \\
87.7 \\
57.3\end{array}$ \\
\hline $\begin{array}{l}\text { Owner } \\
\text { Households } \\
\text { Tax-exempts } \\
\text { Insurance co. }\end{array}$ & $\begin{array}{r}44.1 \\
4.0 \\
4.0\end{array}$ & $\begin{array}{r}35.4 \\
-11.0 \\
-10.8\end{array}$ & $\begin{array}{r}39.7 \\
-3.5 \\
-3.0\end{array}$ & $\begin{array}{r}61.9 \\
-37.2 \\
44.3\end{array}$ & $\begin{array}{r}52.7 \\
-53.0 \\
33.9\end{array}$ & $\begin{array}{r}57.2 \\
-45.3 \\
39.2\end{array}$ & $\begin{array}{r}57.5 \\
-21.5 \\
23.4\end{array}$ & $\begin{array}{r}48.2 \\
-37.6 \\
11.2\end{array}$ & $\begin{array}{r}52.7 \\
-29.8 \\
17.3\end{array}$ \\
\hline Overall & 32.0 & 21.4 & 26.7 & $\mathbf{3 8 . 4}$ & 27.7 & 33.0 & 37.2 & 26.2 & 31.5 \\
\hline
\end{tabular}

The calculations in Table 6 are based on an assumed pre-tax real rate of return of $10 \%$ per annum and at three different inflation rates. ${ }^{74}$ The "actual" inflation rate of $6.77 \%$ is the U.S. average rate from 1970-79. For an asset category-machinery, for example-the effective tax rate is the average of all effective marginal tax rates for all combinations of parameters that include machinery, calculated by assuming a $1 \%$ increase in investment in machinery by industries in the existing proportions that they invest in machinery, financed in existing proportions for each source of finance, and provided by ownership categories in proportion to existing holdings. The total overall rate is the average of all effective marginal tax rates for the eightyone combinations of parameters, weighted by the proportion of total capital invested in each combination. ${ }^{75}$

The effective tax rates in Table 6 describe the incentives and disincentives provided by the tax system for the eighty-one combinations of capital investment prior to any reallocation of capital to equalize after-tax rates of return. What do these calculations indicate? The overall effective tax rate in the United States in 1980 at the "actual" inflation rate of $6.77 \%$ was $37.2 \%$. This rate was decreased by ERTA, taking into account all of the provisions to be phased in by 1986 , to $26.2 \%$. It was then increased by TEFRA to $31.5 \%$.

Thus, as expected, the overall rate of taxation on capital income was lowered by the various tax acts during the Reagan Administration. ${ }^{76}$ Every

74. Id. at 11,305 . The exact effective marginal tax rate depends upon the choice of pre-tax rate of return. For a discussion of the sensitivity of the calculations to this choice, see id at 282-87.

75. Id. at 269.

76. Irrelevant to these calculations are changes which lowered the corporate tax rate at the first two income brackets since it is assumed that all increased investment is made at the highest marginal 
category of assets, except inventory, and every industry, source of finance, and owner has a lower effective tax rate at any inflation rate. Only inventory remains the same since it receives no depreciation allowance or investment tax credit. Among the assets, machinery received the largest percentage reduction in effective tax rates, buildings received some reduction, and inventory none. This variance in effective tax rates causes a distortion in allocation of capital in favor of equipment and away from inventory and structures. At low inflation rates, the effective tax rate of machinery is near zero, which is nearly equivalent to allowing an immediate deduction (i.e., expensing) for investments in machinery.

Subsequent to the King and Fullerton study, Fullerton and Henderson published another study solely of U.S. marginal total effective tax rates on capital income. ${ }^{77}$ Table 7 summarizes some of the calculations from this study. ${ }^{78}$ The figures are consistent with, but somewhat different from, those in Table 6 . This study concludes that, at an inflation rate of $7 \%$ and a real after-tax rate of return of $5 \%$, an overall subsidy of $4 \%$ remains after TEFRA for investment in equipment. Previous studies had shown that the marginal effective corporate tax rate was negative after ERTA and TEFRA, ${ }^{79}$ but the Fullerton and Henderson study shows that the income tax subsidy at the corporate level is sufficient to more than offset personal and property taxes so that a subsidy still remains.

TABLE 7

Marginal Total Effective Rates, Corporate Sector (BASED ON 7\% INFLATION RATE AND 5\% REAL AFTER-TAX RATE OF RetURN)

\begin{tabular}{lccccc}
\hline Asset & 1981 & $\begin{array}{c}\text { ERTA } \\
1981\end{array}$ & $\begin{array}{c}\text { TEFRA } \\
1982\end{array}$ & $\begin{array}{c}\text { No debt } \\
\text { fnancing }\end{array}$ & $\begin{array}{c}\text { All debt } \\
\text { financing }\end{array}$ \\
\hline Equipment & $5.4 \%$ & $-72.1 \%$ & $-4.0 \%$ & $48.3 \%$ & $-208.2 \%$ \\
Structures & 49.6 & 37.7 & 37.7 & 66.8 & -46.4 \\
Public utilities & 33.2 & 24.0 & 32.6 & 64.0 & -56.1 \\
Inventories & 35.6 & 35.6 & 35.6 & 67.7 & -89.0 \\
Land & 39.9 & 39.9 & 39.9 & 69.4 & -66.5 \\
Overall & 34.5 & 23.6 & 30.0 & 64.0 & -84.7 \\
\hline
\end{tabular}

tax rate. The increased carryover period for net operating losses and the safe-harbor leasing provisions are irrelevant, for it is assumed that all new investments are made by profitable corporations which can utilize all incentive provisions. The calculations ignore the personal tax cuts made by ERTA, on the basis that they are offset by inflation and therefore by bracket creep prior to the effective tax date of the indexation of brackets, personal allowances, and the ZEBRA. See id. at 252-53.

77. Fullerton \& Henderson, Incentive Effects of Taxes on Income from Capital: Alternative Policies in the 1980 s (NBER Working Paper No. 1262, 1984).

78. For the source from which the figures in Table 7 were derived, see id. at 28 (Table 4); 37 (Table 5).

79. See, e.g., Auerbach's calculations in Table 5, supra note 66. 
Tables 6 and 7 both illustrate that effective tax rates are sensitive to the financing method. Table 6 shows that these rates are negative for all debtfinanced capital. The debt to equity ratio in the United States is about onethird. Columns 4 and 5 of Table 8 show the effective tax rates of various assets assuming that all investments are made with equity and alternatively that they are made with debt. Without debt financing, the overall total effective tax rate in the corporate sector would rise from $30 \%$ to $64 \%$; with $100 \%$ debt financing, the rate would decrease to $\mathbf{- 8 4 . 7 \%}$.

What is the impact of inflation on these rates? With inflation the overall effective tax rates rise moderately. For example, Table 6 shows that after TEFRA the overall rate rises from $26.7 \%$ with zero inflation to $31.5 \%$ with $6.77 \%$ inflation, and to $33 \%$ with $10 \%$ inflation. What accounts for the moderateness of this rise? The effective tax rate increases due to the nonindexation of depreciation allowances and capital gains. However, under the assumption that all corporations use LIFO accounting for inventory, the effective tax rate for inventory actually decreases since unindexed nominal interest payments are deductible. Moreover, the effective tax rate for all corporate assets is decreased because nominal interest payments are deductible by corporations at the overall average marginal rate of $49.5 \%$ (combination of federal and state taxes) while the overall average marginal tax rate applied to interest receipts is only $23.6 \%$. The combination of these various factors yields a very moderate increase in the effective tax rates as the inflation rate rises. ${ }^{80}$ By asset category, the most pronounced effect is on machinery since depreciation allowances are unindexed. The effective tax rate with respect to retained earnings increases since capital gains are not indexed. Debt finance is further subsidized, however, in that nominal interest rates are deducted at a higher average marginal tax rate than that applied to interest receipts.

The types of effects shown by Table 6 highlight the fact that ad hoc corrections for inflation are an imperfect substitute for indexation. Effective tax rates vary with changes in the inflation rate; moreover, they change unevenly across the parameters in Table 6 , and the resulting dispersion of effective tax rates increases with the increase in inflation. The increased dispersion shown in Table 6 is summarized in Table $8 .^{81}$

80. M. KING \& D. Fullerton, supra note 12, at 244-45; Fullerton \& Henderson, supra note 77, at 32-35.

81. The figures in Table 8 are taken from Table 6. The data are based upon the same distribution of capital stock for each inflation rate, and the calculation does not take into account the possibility that patterns of investment may shift in response to changes in inflation rates. The table summarizes the highest and lowest effective marginal tax rates which have been averaged for several combinations of parameters. Not shown in Table 8 , for example, is that in the separate 81 combinations, in 1980 , the highest effective tax rate was $111.0 \%$ at the actual inflation rate for buildings in manufacturing or commerce financed by new share issues owned by households. $M$. King \& D. Fullerton, supra note 12, at Appendix B. The lowest effective tax rate was $-105.3 \%$ for machinery in commerce financed by debt and owned by tax-exempt institutions. Id. Thus, the absolute spread among the 81 combinations was $216.3 \%$. 
TABLE 8

Dispersion of Effective Marginal Rates

(IN Percent)

\begin{tabular}{|c|c|c|c|c|c|c|c|c|c|}
\hline \multirow[b]{3}{*}{ Year } & \multicolumn{9}{|c|}{ Inflation Rate } \\
\hline & \multicolumn{3}{|c|}{ Zero } & \multicolumn{3}{|c|}{$\underset{(6.77 \%)}{\text { Actual }}$} & \multicolumn{3}{|c|}{$10 \%$} \\
\hline & Low & High & Spread & Low & High & Spread & Low & High & Spread \\
\hline 1980 & -2.0 & 61.0 & 63.0 & -21.5 & 91.2 & 112.7 & -37.2 & 104.6 & 141.8 \\
\hline 1981 & -17.6 & 55.0 & 72.7 & -37.6 & 84.9 & 122.5 & -53.0 & 98.4 & 151.4 \\
\hline 1982 & -8.9 & 57.8 & 66.7 & -29.8 & 87.7 & 117.5 & -45.3 & 101.2 & 146.5 \\
\hline
\end{tabular}

Fullerton and Henderson prepared a more elaborate diagram in Table 9 showing the change in effective tax rates with inflation rates varying from zero to $15 \% .{ }^{82}$ It vividly illustrates the fact that marginal total effective tax rates for the corporate sector and for the economy as a whole are largely invariant with changes in inflation rates. The corporate sector rate is $28.2 \%$ at zero inflation, $26.2 \%$ at $10 \%$ inflation, and $27 \%$ at $15 \%$ inflation.

These conclusions directly contradict the arguments of proponents of the Reagan Administration tax proposals that the interaction of inflation and an unindexed tax base has, in the past, caused the effective tax rates on capital income to rise and discouraged capital investment. ${ }^{83}$ These arguments are also contradicted by the fact that the ad hoc modifications in taxation on capital income since 1960, to take into account the effects of inflation, have more than offset increased effective tax rates due to inflation. The King and Fullerton study includes the following comparisons in Table 10 for 1960, 1980, and 1982, which demonstrate this point. ${ }^{84}$

82. See Table 9. Table 9 is taken from Fullerton \& Henderson, supra note 77, at 34, Figure 1.

83. See supra section I(B).

84. The figures in Table 10 are taken from Table 6 and from M. King and D. Fullerton, supra note 12, at 261 (Table 6.31). Cf. Feldstein \& Summers, Inflation and the Taxation of Capital Income in the Corporate Sector, 32 NAT'L TAX J. 445 (1979) (concludes that inflation substantially increased the effective tax rate on capital income in the nonfinancial corporate sector). 


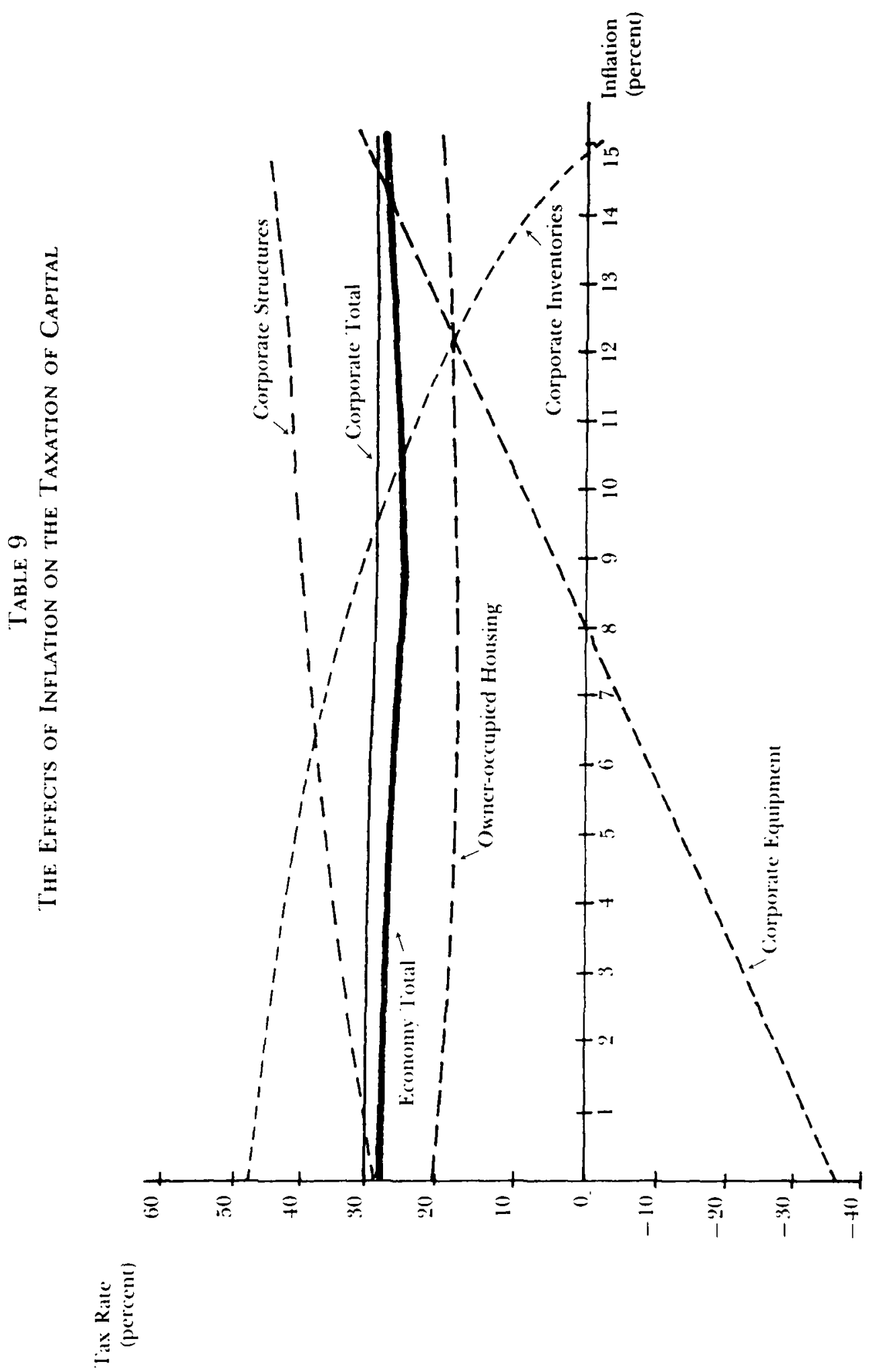


TABLE 10

Overall Effective Marginal Tax Rates

(in Percent)

Inflation rate

\begin{tabular}{lccc}
\hline & \multicolumn{3}{c}{ Inflation rate } \\
Year & Zero & $\begin{array}{c}\text { Actual } \\
(6.77 \%)\end{array}$ & $10 \%$ \\
\hline 1960 & 44.9 & 48.4 & 48.3 \\
1980 & 32.0 & 37.0 & 38.4 \\
1982 & 26.7 & 31.5 & 33.3 \\
\hline
\end{tabular}

Since the calculation of overall rates masks the spreads among individual combinations, King and Fullerton prepared a histogram for the actual inflation rate with 1980 parameters to show the percentage of capital income taxed at various effective tax rates (see Table 11). ${ }^{85}$

TABLE 11

Proportion of Investment Taxed at Each Effective Tax Rate (1980)

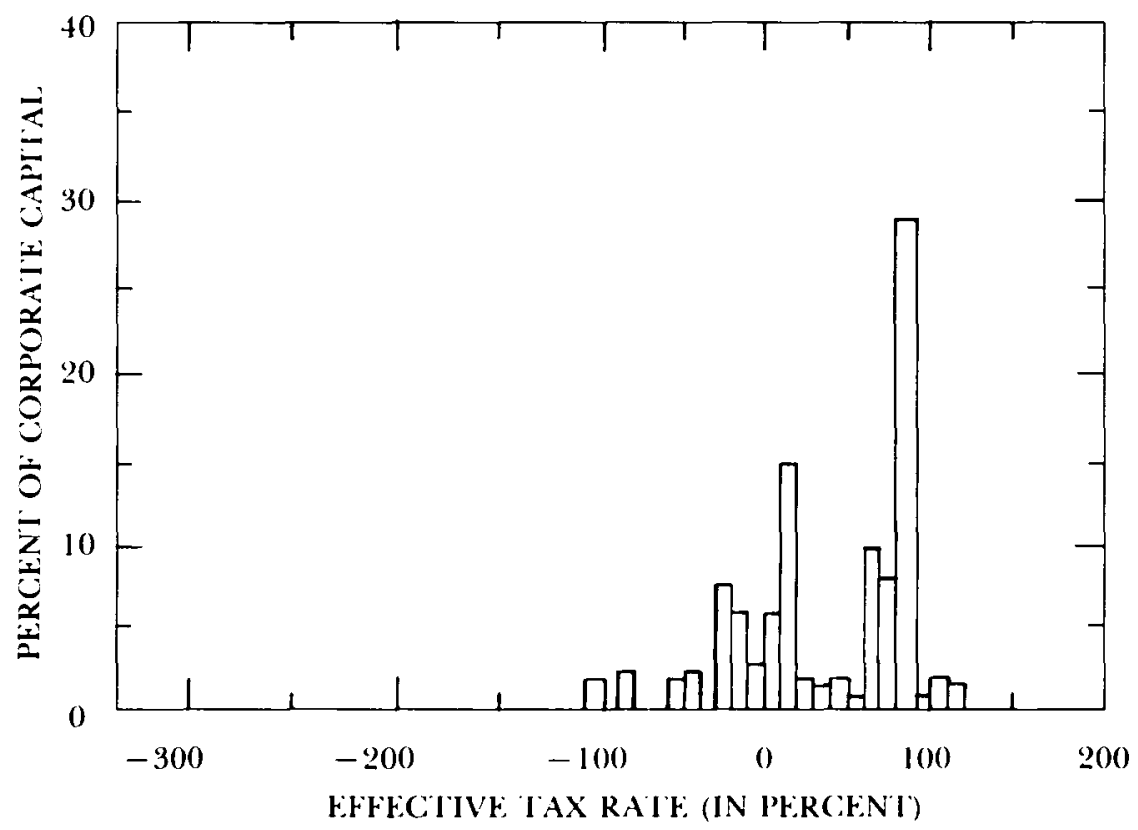

This histogram shows that nearly $30 \%$ of all U.S. capital was taxed at rates between $80 \%$ and $90 \%$, whereas another $30 \%$ was taxed between $-30 \%$ and $20 \%$; rates extended from a low of $-105 \%$ to a high of $111 \%$. The weighted average of these individual rates was $37.2 \%$, as shown in Table 6 . Table 8 also shows that the range of dispersion increases with rising inflation rates. High inflation therefore leads to interasset and interindustry distortions,

85. M. Kinc; \& 1). Fultekron, supra note 12, at 299 , Figure 7.9 . 
apparently even more than it creates intertemporal distortions. Since capital reallocation occurs in response to such variance in tax rates, obvious efficiency gains would occur from a substantial reduction in the dispersion of the interasset and interindustry rates: ${ }^{86}$

Another interesting aspect of the study was the determination of the effect of the repeal of the corporate tax altogether. As shown in Table 6, with personal and property taxes unchanged, the Reagan Administration reduced the overall marginal effective tax rate on capital income from $37.2 \%$ in 1980 to $31.5 \%$ in 1982 at the actual inflation rate of $6.77 \%$ from 1970-79. King and Fullerton calculate that repeal of the corporate tax in 1982 after TEFRA would raise the overall marginal effective tax rate on capital income from $31.5 \%$ to $35.3 \% .{ }^{87}$ Why would the rate rise? As King and Fullerton explain, under the system after TEFRA, the combination of accelerated depreciation, investment tax credits, and interest deductions for new marginal investment more than offsets the corporate tax collected, if any, from that investment. The corporate tax thus operates as a net subsidy to that investment whenever the corporation can fully utilize all the tax benefits. Repeal of the corporate tax would eliminate this net subsidy and taxes on income from old investments would still be collected. In summary, then, the changes during the Reagan Administration have actually reduced the difference between the pre-tax and after-tax rates of return in the corporate sector, since rates would now go up if the corporate tax were repealed. At the same time, these changes contribute to the variation in effective tax rates. Thus little revenue, if any, is collected on new marginal investment but substantial reallocation of capital is occurring as a result of the tax legislation during the Reagan Administration. ${ }^{88}$

86. One economist estimated the deadweight loss from the inefficient allocation of capital resulting from ERTA to be $\$ 3.5$ to $\$ 3.8$ billion, depending upon the assumed inflation rate. Gravelle, Effects of the 1981 Depreciation Revisions on the Taxation of Income from Business Capital, 35 NAT'L TAX J. 1, 17 (1982). This study measures only interasset allocation costs. It does not measure industry misallocation or intertemporal misallocation associated with the overall taxation of capital income. It also applies only to corporate capital and not to total capital. See Fullerton \& Henderson, supra note 77 , at 46.

Auerbach calculated the deadweight loss from misallocation of capital in the corporate sector in 1981 to be over $\$ 5$ billion at a before-tax rate of return of $8 \%$. This figure measured distortions both within and between industries. Auerbach, Corporate Taxation in the United States, 1983 Brookings Papers on Econ. Activity 450, 467-70. For a brief discussion of the difficulties in determining the economic cost of the allocation effects of varying tax rates, see B. Bosworth, supra note 2, at 120.

Jorgenson and Sullivan measured variances in effective tax rates under the capital allowances permitted in 1980 and compared these with proposals considered by Congress, including the Reagan Administration proposals. They concluded that at the anticipated inflation rates in 1980, the Reagan Administration proposals if enacted would widen the gaps of effective tax rates among assets and among industries. Jorgenson \& Sullivan, supra note 65, at 210-23, 224.

87. M. Kinc \& D. Fullerton, supra note 2, at 252 (Table 6.25). Fullerton and Henderson calculate that the repeal of the corporate tax would raise the overall effective tax rate in the corporate sector from $30 \%$ to $32.8 \%$. Fullerton and Henderson, supra note 77, at 28, Table 4 .

88. The King and Fullerton study includes information to compare overall effective tax rates on capital income and growth in the four countries covered by the study. That information is presented in the following table, copied from M. KING \& D. Fullerton, supra note 12, at 301 (Table 7.14). 
Because of the capital allocation distortions after ERTA and TEFRA, many economists and tax policy analysts have argued for the modification of the income tax so that capital income is taxed more neutrally with respect to both inflation and type of investment. ${ }^{89}$ Section III discusses whether such reforms are available.

\section{B. Investment Incentive Effects of ERTA and TEFRA}

As described earlier, ERTA and TEFRA were designed to enhance tax incentives for business capital investment through ACRS, a liberalized investment tax credit, and safe-harbor leasing. Bosworth has recently investigated whether ERTA and TEFRA accomplished their intended effect of increased capital investment. ${ }^{90}$

Bosworth begins by documenting the investment boom that occurred in 1983-84. Between the fourth quarter of 1982, the trough of the recession, and the fourth quarter of 1984, total business fixed investment increased by

TABLE 10

Comparison with Alternative Growth Rates

(In Percentages)

\begin{tabular}{|c|c|c|c|c|}
\hline & $\begin{array}{c}\text { United } \\
\text { Kingdom }\end{array}$ & Sweden & $\begin{array}{c}\text { West } \\
\text { Germany }\end{array}$ & $\begin{array}{l}\text { United } \\
\text { States } \\
\end{array}$ \\
\hline $\begin{array}{l}\text { Average annual growth of GDP } \\
\text { in constant prices }(1960.80)\end{array}$ & 2.3 & 3.2 & 3.7 & 3.5 \\
\hline $\begin{array}{l}\text { Average annual growth of } \\
\text { nonfinancial corporate capital } \\
\text { in constant prices }(1960-80)\end{array}$ & 2.6 & 4.7 & 5.1 & 3.7 \\
\hline $\begin{array}{l}\text { Weighted standard deviation of } \\
1980 \text { tax rates }\end{array}$ & 86.2 & 82.9 & 53.5 & 52.5 \\
\hline Coefficient of variation & $2,134.9$ & 232.7 & 111.2 & 140.9 \\
\hline $\begin{array}{l}\text { Overall effective tax rate } \\
1960 \\
1970 \\
1980 \\
\end{array}$ & $\begin{array}{r}53.8 \\
33.6 \\
3.7\end{array}$ & $\begin{array}{l}33.9 \\
41.6 \\
35.6\end{array}$ & $\begin{array}{l}52.5 \\
49.1 \\
48.1\end{array}$ & $\begin{array}{l}48.4 \\
47.2 \\
37.2\end{array}$ \\
\hline
\end{tabular}

Sources: United Kingdom: Blue Book. Sweden: National Accounts. Germany: Bundesbank and Statistical Office. United States: Survey of Current Business.

Dispersion in rates is represented by the coefficient of variation, a percentage result obtained by dividing the standard deviation by the overall effective tax rate. The study draws no conclusion from these figures about the relationship of taxation of capital income and capital accumulation. It is interesting to note, however, that West Germany, with the highest overall effective tax rate in 1980 , also had the lowest dispersion of rates and the highest growth rates. The United Kingdom had the lowest overall effective tax rate in 1980, the greatest dispersion, and the lowest growth rates.

89. See, e.g., B. Bosworth, supra note 2, at 116-121, 201; M. KING \& D. Fullerton, supra note 12 , at 308; Fullerton \& Henderson, supra note 77, at 42, 45; Auerbach, Whither the Comporate Tax?: Reform After ACRS, 35 NAT'L TAX J. 275, 283-85 (1982); Gravelle, supra note 86, at 17-19; Hulten \& Wykoff, Economic Depreciation and Accelerated Depreciation: An Evaluation of the Conable-Jones 10-5-3 Proposal, 34 NAT'L TAX J. 45, 58-59 (1981); Jorgenson \& Sullivan, supra note 65, at 223-27. Feldstein has suggested that within certain ranges of inflation, real rates of return, and length of asset lives, accelerated depreciation methods are acceptable substitutes for indexation of capital recovery allowances. Feldstein, Adjusting Depreciation in an Inflationary Economy: Indexing Versus Acceleration, 34 Nat'L TAX J. 29 (1981).

90. Bosworth, Taxes and the Investment Recovery, Brookings Papers on Economic Activity 1 (1985). His study was reviewed in The Economist, Aug. 10, 1985, at 20. 
$33 \% .91$ This overall gain in investment demand is concentrated in producers' durable equipment which rose $42 \% .{ }^{92}$ Particularly large increases were $59 \%$ for office equipment (including personal computers) and $73 \%$ for business purchases of automobiles. ${ }^{93}$

As described in the previous section, effective tax rates on most types of capital were reduced under ERTA and TEFRA, but they were reduced by widely varying amounts. If this legislation had a significant impact on investment decisions, one would expect the composition of increased investment demand to reflect these varyingly lowered tax rates. Bosworth finds, however, no significant correlation between the investment demand for specific assets and the relative magnitude of the tax reduction. ${ }^{94}$ In particular, significant tax reductions for office equipment (including computers) and automobiles did not occur under ERTA and TEFRA. ${ }^{95}$

Bosworth concludes that effective tax rates matter, but that the cost of capital between 1980 and 1984 may have been more influenced by changes in the specific prices of assets relative to general price level changes and to changes in the costs of funds. ${ }^{96}$ For example, the specific price increases of computers and automobiles were less than changes in the general price level. ${ }^{97}$ Moreover, he concludes that effective tax rate calculations may not adequately take into account the extent to which specific types of assets are debt-financed. ${ }^{98}$ For example, real property is frequently significantly debtfinanced. Computers and automobiles may be significantly debt-financed also. Accordingly, the ability to debt finance certain types of assets may explain in part the significant demand for these assets which did not benefit significantly from ERTA and TEFRA. Of course, the benefit of the interest deduction existed prior to ERTA and TEFRA, so this cuts against arguments that the specific tax reduction of ERTA and TEFRA contributed significantly to investment demand.

Bosworth's specific asset approach may be rejected by others in favor of the significance of the aggregate increase in investment demand that occurred in 1983-84 and the influence of tax reductions on increasing aggregate stock market prices and lowering interest rates. ${ }^{99}$ His study may also be cited for his suggestions about problems with effective tax rate calculations which often overlook the significance of debt-finance and the differential ability of assets to be debt-financed.

Bosworth's study can thus be used by both believers in and sceptics about the magnitude of importance of ERTA and TEFRA to the recent significant

91. Id. at 1 .

92. Id. at 3, Table 1.

93. Id.

94. Id. at 34 .

95. Id.

96. Id.

97. Id. at $9,17$.

98. Id. at 27-35.

99. See, for example, the comments by Summers on Bosworth's study. Id. at 42-45. 
increases in investment demand. Since more concensus has developed about the importance of effective capital allocation through neutral taxation than about the incentive effects of tax reductions for capital income, Section III discusses whether an income tax can ever achieve allocation efficiency through neutral taxation of capital income.

\section{III}

\section{Toward an Investment Neutral Income Tax}

This section discusses the necessary features of an investment neutral income tax system. Neutrality in this sense means that investor choice among assets remains unaffected by the income tax. ${ }^{100}$ For example, assume that the economy is divided into sectors $A$ and $B$, that there is no income tax, and that the real rate of return in both sectors is $10 \%$. An income tax is then imposed on sector $A$ at a flat rate of $50 \%$. In a competitive economy, one would expect capital to shift from the more heavily taxed sector $A$ to the tax-exempt sector $B$ until after-tax rates of return were in equilibrium. This equilibrium would be reached for example when the before-tax rates of return in sectors $A$ and $B$ are $14 \%$ and $7 \%$ respectively. This type of income tax is not neutral because it affects investor choice between sectors $A$ and $B$ and causes corresponding efficiency losses. If the flat $50 \%$ income tax had been applied equally to sectors $A$ and $B$, the before-tax rate of return of $10 \%$ would have been equally reduced to an after-tax rate of return of $5 \%$ in both sectors, so that no investment shift between the sectors would have occurred because of the income tax itself. Accordingly, such a tax is neutral in the sense discussed in this section. ${ }^{101}$

All of the following features of the income tax must exist to create such a neutral income tax system: economic depreciation at replacement cost; no investment tax credits or other investment incentives; indexation for inflation; taxation of accrued real capital gains; and integration of the corporate and personal income tax. ${ }^{102}$ This section does not address all features of an

100. See Samuelson, Tax Deductibility of Economic Depreciation to Insure Invariant Valuations, 72 J. PoL. ECON. 604 (1964).

101. Another type of neutrality and efficiency issue is not discussed here. Proponents of the consumption tax note that the income tax is not neutral with respect to the choice between current and future consumption. See, e.g., Bradford, The Case for a Personal Consumption Tax, in What Should Be TAXed: Income or Expenditure? 75, 96-101 (J. Pechman ed. 1980). Since the income tax base includes savings, by definition it creates a differential between before-tax rates of return to investment and after-tax rates of return to the saver, thereby creating a disincentive to save and postpone consumption. The consumption tax, on the other hand, excludes savings from the tax base, thereby imposing a zero effective tax rate on capital income and taxing present and future consumption at the same rate (assuming constant tax rates). This nonneutrality is not a feature of this discussion, for the purpose here is to determine how to achieve neutrality with respect to choice of type of investment within the context of an income tax. Some would argue, however, that intertemporal efficiency is more important than investment choice efficiency. See, e.g., Boskin, $A$ Closer Look at Tax Neutrality Toward Investment, 29 TAX Notes 652 (1985).

102. See, e.g., U.S. Dep'T Of The Treasury, Blueprints for Basic TaX Reform (1977); INSTITUTE for Fiscal Studies, The Structure and Reform of Direct Taxation 30-40 (1978) (Report of a Committee Chaired by J. E. Meade). Such a federal income tax system will not eliminate all nonneutrality with respect to capital taxation because of the existence of state taxes, including both 
"ideal" income tax. It excludes discussion of the specific treatment of owneroccupied housing and tax-exempt bonds, two of the most notable types of investment which currently receive nonneutral income tax treatment. This omission results from the likelihood that any future tax reform will leave intact some of the present advantages afforded these investments. Also, the neutrality system developed in the following discussion can be applied to these assets either directly or by proxy if the political will to do so ever exists.

Also omitted is discussion of accrual of capital gains. The realization doctrine reflects both measurement, liquidity, and bunching problems associated with taxing accrued but unrealized gains. Several commentators have proposed that an appropriate substitute for accrual taxation is realization taxation with an interest charge imposed for deferral, based upon an assumed pro rata allocation of the total gain over the number of years in the total holding period. ${ }^{103}$ Accordingly, a reasonable and administratively feasible proxy exists for direct accrual taxation. ${ }^{104}$ Also omitted from the discussion is integration of the personal and corporate income tax. Much analysis at the technical level has already been accomplished on this topic. ${ }^{105}$ This analysis and the existence of integration systems in several European countries show that integration with respect to dividends is feasible. Thus, the groundwork for handling these various features of the income tax exists; what remains is the political determination to enact the relevant proposed solutions.

This section addresses more narrowly the remaining features of a neutral income tax system: economic depreciation, neutral investment incentives, and inflation. It covers these factors because they were prominent underlying considerations in the Reagan Administration tax program in 1981 and 1982. In particular, as described earlier, ${ }^{106}$ any attempt at economic depreciation was abandoned in favor of capital recovery allowances and investment tax credits designed to encourage capital investment, offset the effects of inflation in an unindexed income tax, and simplify calculations for capital recovery. Also, as discussed earlier, ${ }^{107}$ this part of the Reagan Administration tax program did nothing to move the income tax toward neutrality. Moreover,

income and property taxes. Also excluded from the list of features and from the discussion are timing and accounting rules, such as cash and accrual mismatching, or capitalization versus expensing choices. The fact that our income tax has certain special tax regimes, such as those for tax-exempt organizations and insurance companies is also ignored. These aspects of the income tax obviously affect the extent to which capital income is taxed neutrally. Wealth taxes are also excluded.

103. E.g., Cong. Budget Office, Revising the Individual Income TaX 70-81 (1983); Institute FOR Fiscal StUdies, supra note 102, at 129-35; Brinner, Inflation, Deferral and the Neutral Taxation of Capital Gains, 26 NaT'L TAX J. 565 (1973); Diamond, Inflation and the Comprehensive Tax Base, 4 J. PuB. ECON. 227 (1975); Helliwell, The Taxation of Capital Gains, 2 CAN. J. Econ. 314 (1969). In response to the bunching problem, the realized gain could be taxed at the marginal tax rate applicable in the year of realization assuming that $\mathrm{l} / n$th of the gain were realized in the year of realization, where $n$ is the number of years in the holding period for the asset.

104. But see infra note 253 .

105. E.g., Blueprints for Basic TAX Reform, supra note 102, at 68-75; C. Mclure, Must Corporate INCOME Be TAXed Twice? (1979); Warren, The Relation and Integration of Individual and Corporate Income Taxes, 94 HARv. L. REv. 717 (1981).

106. See supra text accompanying notes 50-59.

107. See supra text accompanying note 82 . 
congressional tax reform proposals, which appear to have substantial support, retain many of the basic features of our present income tax which are causing this nonneutrality. ${ }^{108}$ Discussion of the factors of economic depreciation, investment incentives, and inflation can help determine whether retention of nonneutral features results from technical and administrative inability to measure capital income properly. Alternatively, retention may reflect, not a lack of ability to handle these features properly by legislation, but the presence of a political desire expressly to retain these nonneutralities for certain investments, such as home ownership, state and local bonds, or equipment.

Distinguishing between technical and administrative difficulties which cannot practically be overcome and those which can be handled by legislation facilitates identification of the purpose for the existence of nonneutral features in the income tax. Knowing this purpose then allows one to determine appropriate corollary features of the income tax-for example, whether the income tax should contain an unlimited interest deduction. Knowing this purpose also aids in determining whether a consumption tax may be preferable to the income tax. To the extent that the purpose is political, such a politically chosen nonneutrality is likely to be similarly necessary under the consumption tax; no logical support for the consumption tax can be based solely on these nonneutral features of the income tax.

The following discussion addresses various aspects of a neutral income tax in the following order: (a) economic depreciation; (b) investment incentives; (c) deductibility of interest; (d) tax treatment of losses; and (e) inflation. The discussion of items (a) through (d) assumes the absence of inflation, and the impact of inflation is taken up in item (e).

\section{A. Economic Depreciation}

To determine whether a neutral income tax can be established, economic depreciation must be quantified and then replicated in the statutory depreciation system. Can this be done? Ideally, economic depreciation is a measure of the change from the beginning to the end of the taxable year in the present value of the gross income still to be produced by a particular asset owned by a particular taxpayer. ${ }^{109}$ That value may change from aging and the mere passage of time, and it may also be affected by inflation and changes in the relative value of the asset. In real life, this depreciation figure cannot be accurately measured. Assets are largely owner-utilized and depreciate in place so that no observable dollar cost associated with actual consumption by the particular taxpayer exists. Thus, there is no direct evidence on which to base tax depreciation. To approximate such a measurement, each particular taxpayer could be permitted to state his belief as to such depreciation values

108. For a discussion of these proposals, see infra text accompanying notes 207-63.

109. See Samuelson, supra note 100. 
each year on his return. For obvious administrative reasons, no selfassessment income tax could adopt such a subjective system of inputs.

The studies of Hulten and Wykoff conclude that rates of economic depreciation can be established objectively from market data for used asset prices. ${ }^{110}$ They define economic depreciation to be the decline in asset value due to aging, and they adjust the market data for general and relative price effects.11 Their calculations for thirty-two classes of assets show that the pattern of economic depreciation due to aging is approximately that of geometric or declining balance depreciation and can be stated as a single rate for each category of assets. They argue that measurement of depreciation in this fashion is sufficiently accurate for policy purposes to base tax depreciation upon such empirical evidence. ${ }^{112}$

Those who favor a consumption tax and, therefore, expensing of capital investment, criticize the policy conclusion drawn from the Hulten and Wykoff studies. They point out that their work is still a proxy for a true measurement of economic depreciation, which can never be attained; under a consumption tax, in contrast, the whole problem is entirely eliminated and is therefore unchallengeable as a superior method of measuring the tax base. ${ }^{13}$ Critics note that not enough homogeneous samples are available for a sufficient range of assets to make adequate empirical determinations. ${ }^{114}$ It is also noted that used asset market prices can reflect a bias that is not present with respect to assets depreciated in place. Lemons may dominate the used asset market, so that calculations using prices in this market may overstate rates of depreciation relative to those which would be found using assets which are never sold. ${ }^{115}$ Also, market prices reflect transactions costs, including such costs as removal and installation of assets, which are not relevant to assets which are not sold. Despite these criticisms, some economists find these and

110. Hulten \& Wykoff, The Measurement of Economic Depreciation, in DePRECiation, INFLATION, AND the TaXation of InCOME from Capital 81 (C. Hulten ed. 1981).

111. Id. at $85,86-88,301$ n.7.

112. Id. at 82-83, 112 .

113. See, e.g., Ture, The Accelerated Cost Recovery System: An Evaluation of the 1981 and 1982 Cost Recovery Provisions, in New Directions in Federal Tax Policy for the 1980s 47 (C. Walker \& M. Bloomfield eds. 1983). Skinner notes that Ture's analysis of depreciation provisions under ERTA and TEFRA is "marred by his economic analysis which holds discount rates and gross interest rates fixed as marginal tax rates vary." Skinner, Book Review, 22 J. Econ. Lrr. 1657, 1658 (1984).

114. See Mills \& Rosen, Depreciation of Real Property in Tax Reform Proposals, 27 Tax Notes 319, 320 (1985); Ture, supra note 113, at 74-75. King and Fullerton note that Hulten and Wykoff use "blue book" and other business asset price data for eight asset categories. They then derive the 32 depreciation rates from the eight directly estimated rates. M. KING \& D. FuLLERTON, supra note 12, at 214.

115. Hulten \& Wykoff, supra note 110 , at $96-99,127-28$ (comments by DeLeeuw); Mills \& Rosen, supra note 114, at 320. Hulten and Wykoff respond that this is not a substantial problem because buyers are sufficiently sophisticated to prevent sellers from offering only inferior used equipment which buyers cannot identify as inferior. Hulten \& Wycoff, supra note 110, at 96-99. The "lemons" argument does not depend on a lack of sophistication, however. Sellers always have more information about the asset than the buyer does, so the buyer is likely to discount the price for a certain amount of negative information that he does not have; and a seller would only find it worthwhile to sell the asset if it is worth no more than the buyer's discounted price (that is, the asset is at least somewhat a "lemon"). Empirical evidence needs to be obtained and evaluated to determine the existence and importance of asymmetric market information. 
other arguments insufficient to rebut the conclusion drawn by Hulten and Wykoff that economic depreciation can be measured adequately so that as a policy matter the results from this methodology of research should be used as a basis for a tax depreciation schedule, rather than continuing to adopt capital recovery methods like ACRS which are an ad hoc hodgepodge of depreciation, inflation adjustments, and investment incentives. ${ }^{116}$

The empirical work of Hulten and Wykoff attempts to measure economic depreciation in terms of the rate of decline in the value of assets due to aging. ${ }^{117}$ The change in the value of an asset can also be affected by general and relative price changes. Samuelson has shown that if valuations of assets are to be independent of tax rates, then accrued capital gains and losses from changes in general and relative prices must be netted against declines in value due to aging, so that economic depreciation should equal this overall change in value. ${ }^{118}$ The following example illustrates this point.

Example 1. Assume that the purchase price of a widget in Year One is 100 , and that the economic depreciation rate, as calculated by Hulten and Wykoff, is 0.15 . The actual value of a one-year-old widget at the beginning of Year Two is 0.90 . If economic depreciation takes into account only the decline of Year One due to aging, the depreciation deduction for that decline is $15(0.15 \times 100)$. The value of the widget did not in fact decline by that amount because the decline in value of 15 due to aging was offset by an increase in value of 5 due to a relative change in asset prices. Thus, the depreciation deduction should be only 10 , the difference between the purchase price of 100 in Year One and the value of 90 at the beginning of Year Two.

This calculation of the depreciation deduction would be equivalent to taxing an accrued but unrealized gain of five at ordinary income rates. This objective of the Samuelson method is not going to be achieved, however. The accrued gain of five is not observable since the asset is not sold. This measurement problem is so substantial that no attempt will ever be made under the income tax to accrue and tax annually such changes in value. As discussed earlier, commentators have proposed that on the sale of assets the realized gain be increased by an interest factor due to the deferral of recognition of the gain. ${ }^{119}$ Such a proposal, when applied to depreciable assets, has the advantage of providing a proxy for the accrual of gains and losses necessary to make economic depreciation more nearly neutral along the lines established by Samuelson. The proxy is not an exact substitute for accrual, because the interest charge for deferral is based on the assumption of even annual accrual during the holding period for the asset; actual accrual based on general and relative price changes is likely to be different. The

116. To review other criticisms of the Hulten and Wykoff studies, see, for example, Hulten \& Wykoff, supra note 110, at 126-29 (comments by DeLeeuw), 129-32 (comments by Taubman), 300 (comments by Eisner), 300-02 (comments by Jorgenson); Mills \& Rosen, supra note 114, at 320-22.

117. Hulten \& Wykoff, supra note 110 , at 85 .

118. Samuelson, supra note 100.

119. See supra text accompanying note 103 . 
proxy also does not apply where depreciable assets are owner-utilized and are never sold.

Bulow and Summers suggest that if tax depreciation is established ex ante, based on the aging of assets alone, and not ex post, based on aging and relative price changes, the depreciation rate will be too low. ${ }^{120}$ They argue that because gains and losses from relative price changes are not accrued and taxed annually, the capital risk associated with the uncertainty of relative price changes is substantial because it is not "shared" with the government, and to the extent that it is ultimately shared through the realization doctrine, the mistiming under the realization doctrine causes the risk not to be shared equivalently to that associated with ordinary income streams. Accordingly, the ex ante tax depreciation schedule must be adjusted upward to take account of the substantial risk premium associated with relative price changes. ${ }^{121}$ Their empirical investigation suggests that a $6 \%$ depreciation rate for the risk premium should be added to the depreciation rate calculated for aging. ${ }^{122}$ If this figure is approximately accurate, its omission obviously causes a substantial understatement of economic depreciation. Bulow and Summers also suggest that the depreciation proxy for the risk premium may need to be greater for longer-lived assets since they are likely to be subject to greater asset price fluctuations than are shorter-lived assets. ${ }^{123}$

The discussion of economic depreciation shows that neutrality in the sense discussed here is not totally achievable under an income tax. First, since actual economic depreciation due to aging of assets cannot be known for the individual taxpayer, a proxy must be substituted, such as Hulten and Wykofftype empirical observations from market data for used assets. Second, to achieve neutrality, Samuelson has shown that gains and losses due to changes in general and relative prices of assets must be accrued and taxed at ordinary income rates. Again, these changes are not sufficiently observable to be accrued, and an interest proxy can be provided only for assets which are sold. Empirical evidence suggests that the failure to account for relative price changes may substantially understate economic depreciation so that some appropriate additional depreciation rate must be added to the ex ante depreciation schedule as a proxy for proper accrual accounting. More empirical work is needed to determine to what extent neutral taxation of many depreciable assets may depend on proper measurement of accrued gains and losses as opposed to proper measurement of depreciation due to aging, particularly when, as discussed in section III E, depreciation is indexed for inflation.

120. Bulow \& Summers, The Taxation of Risky Assets, 92 J. PoL. Econ. 20 (1984).

121. Id. at $25-29$.

122. Id. at 32.

123. Id. at 31. For a discussion of the application of the arguments by Bulow and Summers to depreciation rates for real estate, see Mills \& Rosen, supra note 114, at 321-22. Mills and Rosen note that Hulten and Wykoff measured a 3\% depreciation rate for real estate due to aging, but that rate must be increased to at least $9 \%$ to take account of the risk associated with relative price changes. Id. at 322. 


\section{B. Investment Incentives}

Unless marginal income tax rates are substantially reduced, Congress is likely to continue providing some form of investment incentive or subsidy for nonresidential tangible investment. Congress has used both accelerated depreciation and investment tax credits as investment incentives. It continued this practice in 1981 with ACRS by allowing "recovery" at accelerated rates over artificially short recovery periods. This type of accelerated depreciation is not sufficiently calibrated to maintain neutrality. Bradford has shown the difficulty of achieving neutrality under an accelerated depreciation scheme. Such a neutral scheme requires knowledge of interest rates and marginal tax rates, ${ }^{124}$ and must utilize increasing rates of acceleration with increasing asset durability. ${ }^{125}$

In 1981, Congress also enhanced the amount of the investment tax credit. The credit continues to apply primarily to tangible personal property, ${ }^{126}$ but Congress increased the amount of the credit to $6 \%$ for assets in the three-year recovery period and $10 \%$ for assets in the five-, ten-, and fifteen-year recovery periods. ${ }^{127}$ In 1982 , Congress began requiring that the depreciation base be reduced by $50 \%$ of the credit. ${ }^{128}$ Alternatively, the taxpayer may choose, instead of this basis adjustment, a $4 \%$, rather than a $6 \%$, credit or an $8 \%$, rather than a $10 \%$, credit. ${ }^{129}$ Bradford has shown that to design a neutral credit, the depreciation base must be reduced by the full amount of the credit, as the relative price of the asset to the taxpayer for income tax purposes is the price of the asset net of the tax credit. ${ }^{130}$ The amount of the credit percentage must also be calibrated to increase with asset durability. ${ }^{131}$ The current system neither requires that the depreciation base be net of the credit nor, Bradford shows, sufficiently calibrates the credit in relation to asset durability. ${ }^{132}$ Bradford demonstrates that designing a neutral credit system may be difficult because it requires knowledge of a "target" before-tax rate of return and interest rate to yield from the credit the increased private savings

124. Bradford, Issues in the Design of Savings and Investment Incentives, in Depreciation, INFLATion, and the TAXation of Income from Capital 13, 23-24 (C. Hulten ed. 1981). Bradford shows that the objective of a neutral accelerated depreciation system would be to obtain a proportional difference between interest rates and social rates of return on investment, that is, to reduce proportionally the tax wedge between private returns on savings and social returns on investment. To achieve this objective, the degree of acceleration must be calibrated to the interest rate and applicable marginal tax rate. Id.

125. Id. at 24-25.

126. See I.R.C. \& 48(a) (Lawyers Co-op. 1984 \& Supp. 1985).

127. Id. \& 46(a)(1) \& (c)(7) (Lawyers Co-op. Supp. 1985).

128. Id. \& $48(\mathrm{q})(1)$.

129. Id. \& 48(q)(4) (Lawyers Co-op. 1984).

130. Bradford, supra note 11, at 31; see generally Bradford, Tax Neutrality and the Investment Tax Credit, in The Economics of Taxation 281 (H. Aaron \& M. Boskin eds. 1980) [hereinafter cited as Neutrality]. This basis adjustment eliminates differential effects on the demand price for assets as a function of marginal tax rates, thereby preventing tax arbitrage. Bradford, supra note 124, at 33 . For a discussion of tax arbitrage, see infra text accompanying notes 139-47.

131. Bradford, supra note 124, at 31-33.

132. See id. at 32-33. 
necessary to generate precisely the targeted rate of return. ${ }^{133} \mathrm{~A}$ further complication is that a different calculation applies to each type of depreciation. ${ }^{134}$

Economists have frequently noted that the consumption tax, in contrast to the income tax, yields a neutral investment incentive. Because all investment is deducted from the consumption tax base, all capital income is taxed at a zero effective tax rate. ${ }^{135}$ Similarly, can a neutral investment incentive be designed for the income tax so that some positive tax is paid on capital income without changing taxpayers' choice among assets? Harberger has suggested the following simple incentive technique: a specified percentage of the purchase price of the asset, $k$, is deducted in the year of the purchase, and then economic depreciation is allowed on $100(1-k)$ percent of the purchase price. ${ }^{136}$ For example, if $k=10 \%$, the taxpayer deducts $10 \%$ of the purchase price in the year of purchase and applies economic depreciation to the remaining $90 \%$ of the purchase price. In effect this incentive method applies the consumption tax to $10 \%$ of the purchase price and the income tax based on economic depreciation to the other $90 \%$. If the percentage deducted in the year of purchase were raised to $100 \%$, the incentive would be equivalent to a consumption tax on $100 \%$ of the investment. ${ }^{137}$ Congress can set the level of the percentage deduction, taking into account both the degree of incentive it desires to provide for investment demand and the budgetary constraints due to lost tax revenues from the incentive. ${ }^{138}$

133. Id. at 33 .

134. Id.

135. Id. Thus, under the consumption tax, the rate of return on consumption foregone obtained by all savers equals the social yield on investments, even though the tax base is subject to a graduated tax. For a discussion of the necessary conditions to achieve the equivalence of expensing the investment and exempting the income from the investment, see Graetz, Implementing a Progressive Consumption Tax, 92 HaRv. L. Rev. 1575, 1597-1605 (1979).

136. Harberger, Tax Neutrality in Investment Incentives, in The Economics of TAXation 299, 307-09 (H. Aaron \& M. Boskin eds. 1980). Bradford has noted that the Harberger proposal can be transferred into a constant investment tax credit, but the transfer requires a corollary adjustment to the depreciation base. With a constant investment tax credit, the depreciation base equals 100 ( 1 $-(k / m)) \%$ of the purchase price, where $k=$ the investment tax credit percentage and $m=$ the marginal tax rate. See Bradford, Neutrality, supra note 130, at 298 n.21.

137. As the level of the first-year deduction increases, the rate of return to all savers moves toward the social rate of return on investment since the marginal tax rate is moving toward zero. In contrast, a neutral investment tax credit decreases the wedge between social rates of return and aftertax rates of return without altering the difference among after-tax rates of return due to a graduated income tax. See Bradford, supra note 124, at 16, 33.

138. Sunley has noted that, although any system of accelerated depreciation and investment tax credit can be substituted for another to yield the same degree of incentive in present value terms, Congress sometimes has preferred the credit because in the short run accelerated depreciation involves immediate larger revenue losses than an equivalent credit. Sunley, Acceleration of Tax Depreciation: Basic Issues and Major Alternatives, in Depreciation, Inflation, AND The Taxation of INCOME FROM CAPTTAL 137, 198 (C. Hulten ed. 1981). This type of budget consideration does not come into play in choosing between the Harberger first-year deduction or a constant investment tax credit as described supra at note 128; both are equivalent incentives given tax effect in the year of the asset's purchase, and depreciation is the same under either method. 


\section{Deduction of Interest}

If the income tax incorporates economic depreciation, as described in section III A, the interest paid with respect to debt-financed investment is deductible to compute taxable income. In contrast, under a consumption tax where capital income is subject to a zero effective tax rate, interest is nondeductible. ${ }^{199}$ If a neutral investment incentive like the one described in section III B were included in the income tax, the amount of interest deduction correspondingly must be lowered. Otherwise, less than full taxation of income would be combined with full deductibility of interest, creating an advantage often referred to as tax arbitrage. The following examples illustrate the arbitrage opportunity presented by the mismatching.

Example 2. Assume a taxpayer at the $50 \%$ marginal tax rate borrows $\$ 100,000$ at a $10 \%$ interest rate and invests in a tax-exempt bond yielding $10 \%$. The tax and cash flow effects are summarized as follows:

Cash Flow:

Interest Income

Less Interest Expense

Plus Tax Saved from

Interest Expense

Net Cash Flow

$$
\begin{array}{r}
\$ 10,000 \\
(10,000) \\
5,000 \\
\hline \$ 5,000
\end{array}
$$

The taxpayer obtains the $\$ 5,000$ profit purely from the operation of mismatching tax-exempt income and a full interest deduction. The same effect can be achieved if the tax on capital income is not fully taxed due to the investment incentive described in section III B and interest is fully deductible.

Example 3. Assume that Congress adopted the Harberger investment incentive described in part III B and allowed a $100 \%$ deduction of the purchase price of the asset in the year of the purchase. Such a deduction yields a zero effective tax rate on the income produced by assets which receive the incentive. Assume a taxpayer at the $50 \%$ marginal tax rate borrows $\$ 100,000$ at a $10 \%$ interest rate and purchases an asset for $\$ 200,000$ qualifying for the incentive

139. See, e.g., INSTITUTE FOR Fiscal Studies, supra note 102, at 178; Andrews, A Consumption-Type or Cash Flow Personal Income Tax, 87 HARv. L. REv. 1113, 1153-55 (1974). This treatment of the loan is referred to as the yield-exemption method. Alternatively, cash-flow treatment could be applied to the loan. Cash-flow treatment requires the taxpayer to include loan proceeds into income and then allows the taxpayer a deduction for the repayment of principal and interest, thereby correctly applying equivalent cash-flow treatment to both the asset and the loan. It may be difficult to implement, however. First, taxpayers would probably view such legislation as less acceptable than an adjustment to the interest deduction since they are not accustomed under the present income tax to the inclusion of loan proceeds into income. Second, tracing rules would have to be adopted to determine the portion, if any, of the investment which is debt-financed. For a discussion of tracing rules, see infra text accompanying notes 152-55. For an extensive discussion of the difference between cash-flow and yield-exemption treatment, see Graetz, Expenditure Tax Design, in What Should Be Taxed: Income or Expenditure? 161, 166-84 (J. Pechman ed. 1980). 
$(\$ 100,000$ of borrowed funds plus $\$ 100,000$ tax savings from the deduction). The tax and cash flow effects are summarized as follows:

Cash Flow:

Income on Investment

$\$ 20,000$

Less Interest Expense

$(10,000)$

Less Tax Expense

$(5,000)$

Net Cash Flow

$\$ 5,000$

The net cash flow is identical to that in Example 2.

These tax arbitrage opportunities are well known and have been discussed extensively in academic literature. ${ }^{140}$ Economists have noted, however, that the opportunities for such tax arbitrage may disappear over time, since competitive markets tend to equalize after-tax rates of return on capital income. ${ }^{141}$ Under this assumption, because of the graduated tax structure, taxpayers in the highest marginal tax brackets should shift their investment into the taxfavored asset to take advantage of the mismatch. Such a shift would cause both the pre-tax return on the asset to drop below the rate of return on other assets and interest rates to rise so that no net cash flow would result from the arbitrage. ${ }^{142}$

Example 4. Assume the same facts as Example 2 except that because of tax arbitrage the rate of return on the investment in Example 2 falls from $10 \%$ to $7 \%$, and that interest rates increase to $14 \%$. The tax and cash flow effects are summarized as follows:

Cash Flow:

Income on Investment

Less Interest Expense $(14,000)$

Less Tax Expense

Net Cash Flow

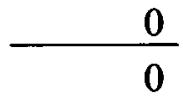

Accordingly, the tax arbitrage profits are zero.

It is uncertain whether the market can force such adjustments to eliminate totally the arbitrage opportunity. It seems unlikely that the relevant markets are in fact perfectly efficient. Further, international flows of capital make it unlikely that interest rates will rise enough, relative to the rate of return on the tax-favored asset, to eliminate completely the tax arbitrage. ${ }^{143}$

140. E.g., Bossons, Indexing for Inflation and the Interest Deduction, 30 WAYNE L. REv. 945, 948-50 (1984); Bradford, The Economics of Tax Policy toward Savings, in The Government AND CaPITAL Formation 11, 38-50 (G. von Furstenberg ed. 1980); Johnson, Tax Shelter Gain: The Mismatch of Debt and Supply Side Depreciation, 61 TEx. L. REv, 1013 (1983); Steuerle, Tax Arbitrage, Inflation, and the Taxation of Interest Payments and Receipts, 30 WAYNE L. Rev. 991, 1002-06 (1984); Warren, Accelerated Capital Recovery, Debt, and Tax Arbitrage, 38 TAx LAW. 549 (1985).

141. See, e.g., Bradford, supra note 140 , at 42-44.

142. If the consumption tax were extended to all real assets, and the tax rate were flat, then interest rates should adjust upward so that all after-tax yields on both real and financial assets would be the same.

143. Economists have also noted that under the present income tax there is a potential for tax arbitrage that the market cannot eliminate. This type of tax arbitrage results from the consumption tax treatment of financial assets such as qualified retirement plans and individual retirement accounts (IRA). For example, money may be borrowed by Individual $S$ from Individual $T$ 's IRA, deposited in $S$ 's IRA, and then reloaned to $T$ who deposits it in his IRA. Each loan receives income tax treatment from the standpoint of Individuals $S$ and $T$ and consumption tax treatment from the standpoint of 
If this market mechanism exists, however, and if all assets receiving the investment incentive are purchased by taxpayers in the highest marginal tax bracket, any gains from tax arbitrage disappear. ${ }^{144}$ No equity effect arises; only misallocation of capital occurs. If the marginal tax rate of the last investors in such assets is below the highest marginal tax rate, however, all taxpayers at marginal tax rates higher than this equilibrium rate receive arbitrage gains. These gains are equivalent to the existence of a negative tax rate. They cause investment which would not even be made in the absence of a tax, because the negative tax makes profitable some investment which yields rates of return below social rates of return. Even assuming that all assets receiving the investment incentive are purchased by taxpayers in the highest marginal tax bracket, the result of the market mechanism will be that high bracket taxpayers hold these real assets and low bracket taxpayers hold the financial assets by which the real investments were made, thereby shifting taxpayers' portfolio choices between real and financial assets. ${ }^{145}$ Such a result could cause efficiency losses by preventing assets from being held by investors best able to utilize them. ${ }^{146}$ Another effect of the market mechanism is that the rate of return on the assets held by the lower-bracket taxpayers exceeds the rate of return on the tax-preferred assets held by the high-bracket taxpayers. ${ }^{147}$ Comparing Examples 3 and 4, the holder of the debt by which the investment was made had an increase in interest return from $10 \%$ to $14 \%$. Thus, in summary, the existence of arbitrage opportunities causes misallocation of capital across assets and temporal misallocation of capital due to the existence of arbitrage gains or negative tax rates. The arbitrage also causes shifts in portfolio choice among taxpayers, and it increases rates of return on financial assets and nontax preferred assets relative to the real assets receiving the tax preference.

Bradford has shown that these effects of arbitrage can be eliminated by matching the investment incentive for real assets with a calibrated consumption tax system for interest receipts and payments. ${ }^{148}$ When the portion of interest payments allowed as a deduction, and the portion of interest receipts taxed as income, is given by

$$
p=\frac{1-k}{1-k m}
$$

where $m=$ the marginal tax rate of the taxpayer and $k=$ the percentage of the purchase price which is allowed as a deduction under the Harberger

each IRA. The market would not be able to eliminate this tax arbitrage. Arbitrage opportunities are limited, however; for example, there are limitations on the amount that can be contributed to these retirement funds. For a discussion of this type of tax arbitrage, see Bradford, supra note 140, at 4950; Steuerle, supra note 140, at 1004-05; Warren, supra note 140, at 565-67.

144. See, e.g., Bradford, supra note 140, at 43-45; Johnson, supra note 140, at 1031-32.

145. See, e.g., Bossons, supra note 140, at 950; Bradford, supra note 140, at 45-46; Johnson, supra note 140, at 1016; Steuerle, supra note 140 , at 103.

146. One purpose of "safe-harbor" leasing is to permit more efficient allocation of assets; however, leasing is not a costless or the most efficient solution to the problem of shifts in taxpayers' portfolio of assets due to tax arbitrage. See infra text accompanying notes 158-66.

147. Bradford, supra note 140 , at 46 .

148. Bradford, supra note 124 , at 28-29. 
incentive, all taxpayers will be indifferent between lending and purchasing assets and arbitrage opportunities will not exist. For example, if $k=100 \%$, as in Example 3, then $p=$ zero and all interest receipts and deductions are eliminated, which is the correct result under the consumption tax. Table 12 shows the value of $p$ corresponding to various rates of $k .^{149}$

TABLE 12

RATE OF INCLUSION OF INTEREST INCOME AND DEDUCTION OF INTEREST Expense Corresponding to Various Rates of Expensing Real Investment (Percentage)

\begin{tabular}{lccccc}
\hline Fraction of & \multicolumn{5}{c}{ Marginal Tax Rate } \\
\cline { 2 - 6 } $\begin{array}{l}\text { Real Asset } \\
\text { Expensed }\end{array}$ & 10 & 20 & 40 & 50 & $\mathbf{7 0}$ \\
\hline $0 \%$ & $100 \%$ & $100 \%$ & $100 \%$ & $100 \%$ & $100 \%$ \\
25 & 77 & 79 & 83 & 86 & 91 \\
50 & 53 & 56 & 63 & 67 & 77 \\
75 & 27 & 29 & 36 & 40 & 53 \\
100 & 0 & 0 & 0 & 0 & 0 \\
\hline
\end{tabular}

The first line reflects the result of the income tax without any deduction incentive and the last line reflects the consumption tax where $100 \%$ of the purchase price is expensed.

Are there any analytical objections to Bradford's suggestion? Under the Harberger method, the percentage of the purchase price is immediately expensed. The subsequent yields on this percentage of investment will be taxed fully. This result, sometimes referred to as the cash-flow treatment of investment, is true for the Harberger incentive to the extent it is equityfinanced. The debt-financed portion of the expensed purchase price under Bradford's suggestion receives the so-called yield exemption treatment. The loan proceeds are not included in the tax base (as they would be under the cash-flow system), but the repayment of principal and interest are not deductible (as they would be under the cash-flow system). The cash-flow treatment for the percentage of the asset's purchase price and the yield-exemption treatment for the loan may yield results that are equivalent to those achieved if the cash-flow method were applied both to the investment and to the loan. ${ }^{150}$ Achieving equivalence where cash-flow and yield-exemption methods are mixed requires that the marginal tax rate be identical in all relevant tax years (the initial year of investment and borrowing and all years in which the loan is outstanding).151 This is likely to be the case only if the rate structure is flat or graduated across large income brackets.

149. Id. at 29.

150. For a discussion of the cash-flow and yield-exemption methods, see supra note 139.

151. Equivalence also requires that the taxpayer repay all principal and accrued interest. The omission of the interest deduction results in an increase in tax liability by an amount equivalent to the interest on the amount of tax deferred because loan receipts are omitted from income in the year of the loan. This equivalence will not occur if the taxpayer fails to repay the loan principal and 
The two systems will also not be equivalent if there exists any relative price change in the loan. Since the investment in real assets is expensed, all of the investment income, even unexpected income and loss, is subject to tax. Yieldexemption treatment of the financial asset means, however, that any gains and losses from relative price changes in the loan are excluded from the tax base. Thus, the two systems can only be equivalent if the future is known perfectly and the ability to borrow funds is unlimited. The existence of both conditions is surely doubtful. The Bradford deduction adjustment therefore mixes a cash-flow treatment for the investment with a yield-exemption system for the loan, making it unlikely that identical consumption tax treatment is applied to both the investment and loan sides of the transaction.

Bradford did not discuss the practical problems of implementing such an interest adjustment. Implementation requires some type of tracing rule to determine the percentage, if any, of the investment receiving the incentive which is debt financed. Development of a specific tracing rule is beyond the scope of this article, but a few general comments about tracing rules can be made. For tax arbitrage reasons, section 265 of the Code eliminates the deduction for interest on debt incurred to purchase tax-exempt bonds (the illustration in Example 2 above). The rule has been effective in preventing only gross tax arbitrage. Since interest is otherwise deductible, ${ }^{152}$ the taxpayer seeking to escape section 265 need only show that indebtedness was not incurred or continued for the purpose of purchasing or carrying the tax-exempt bonds. ${ }^{153}$ Weak tracing systems such as this one are only traps for the unwary; all informed taxpayers show that, of course, loan proceeds were used for other purposes.

Experience with section 265 shows that, for the Bradford interest adjustment system to work, it must be accompanied by a system that traces, with rules, all interest payments. McIntyre has suggested one such system. ${ }^{154}$ Applying McIntyre's proposals, in order to allow for maximum tax planning to eliminate traps for the unwary, all debt would be allocated first to assets which are taxed in accordance with proper income tax measurement (and therefore interest payments with respect to such debt are fully deductible) and second to assets which receive the investment incentive. Accordingly, debt is allocated to assets receiving the investment incentive only to the extent that total debt exceeds the assets in the first category. If after application of McIntyre's tracing rule, part of the investment receiving the incentive is equity-

accrued interest unless the portions not repaid are included in the tax base like cancellation of indebtedness income.

152. See I.R.C. $\$ 163$ (d) (Lawyers Co-op. Supp. 1985), however, which limits the amount of investment interest which can be deducted from ordinary income by individuals. Other provisions which affect the deductibility of interest include I.R.C. \$\$ 170(f)(5), 264 (Lawyers Co-op. 1974).

153. See Oliver, Section 265(2): A Counterproductive Solution to a Nonexistent Problem, 40 TAX L. REv. 351, 359-81 (1985).

154. McIntyre, An Inquiry into the Special Status of Interest Payments, 1981 DuKE L.J. 765. McIntyre attributes debt first to investment in assets which receive proper income tax measurement. A tracing rule could adopt the reverse allocation, or it could allocate debt pro rata between assets which do and do not receive proper income tax measurement. 
financed, the equity is then first allocated to the portion of the purchase price which is expensed, and the interest deduction is calibrated only if the allocated equity is less than the expense. Such a tracing rule accomplishes its purpose but at the expense of substantial complexity both in drafting and in applying appropriate legislative rules. ${ }^{155}$

Interest tracing rules have been criticized by tax analysts who consider it unfair that taxpayers with savings can avoid section 265 by using their savings to purchase tax-exempt bonds and can borrow to purchase other assets for which the interest deduction is allowed, while taxpayers without savings cannot do anything to avoid section 265 because they can only invest in the bonds with borrowed funds. ${ }^{156}$ The following example illustrates this criticism.

Example 5. Assume that the taxpayer foregoes an investment of $\$ 100,000$ which would yield $10 \%$ taxable income and he makes instead the investment described in Example 3 of $\$ 200,000$ $(\$ 100,000$ by foregoing alternative investments and $\$ 100,000$ tax savings from the deduction). The tax and cash flow effects are summarized as follows:

\begin{tabular}{|c|c|c|}
\hline \multirow[t]{2}{*}{ Cash Flow: } & $\begin{array}{l}\text { Income on Investment } \\
\text { Less Foregone Income on } \\
\text { Taxable Investment } \\
\text { Less Taxes Paid on } \\
\text { Investment Income } \\
\text { Plus Taxes Saved on } \\
\text { Foregone Investment }\end{array}$ & $\begin{array}{l}(10,000) \\
(10,000)\end{array}$ \\
\hline & Net Cash Flow & $\$ 5,000$ \\
\hline
\end{tabular}

A comparison of Examples 3 and 5 shows that to disallow the interest deduction on debt-financed investment in the assets receiving the incentive would eliminate the investment by borrowed funds in Example 3, but would not affect the investment in Example 5 where the taxpayer had accumulated savings from which to make the investment. To eliminate the investment in Example 3 is thus viewed as inequitable discrimination against taxpayers without savings with which to make the investment.

The criticism illustrated by Example 5 has no place in the context of this discussion of the design of a neutral investment incentive. The purpose of the design is economic efficiency in the sense that investor choice among assets remains unaffected by the income tax. This purpose dictates that the effective tax rate for all real assets be identical. Efficiency also dictates that the lower limit of the effective tax rate must be zero to prevent unjustified temporal

155. See id. at 782-83. The legislative rules also must be drafted to identify debt for purposes of the interest tracing rules. For example, it would be necessary to identify debt versus equity investments in corporations and to identify finance leases in order to treat the appropriate portion of the "rent" as debt for purposes of the tracing rules.

156. See, e.g., Klein, Borrowing to Finance Tax-Favored Investment, 1962 Wis. L. REv. 608. 
distortions which would result from negative tax rates. Accordingly, interest tracing and calibration are necessary. To yield to the equity objection would prevent the achievement of the neutrality goal. ${ }^{157}$

\section{Treatment of Losses}

Business income and losses are not taxed equivalently under the present income tax. Income is taxed at the taxpayer's marginal tax rate. Losses do not create a claim for an immediate tax refund for the year in which the loss arises. Rather, the loss may be carried back three years to offset taxable income in those years, thereby creating a refund claim for the tax paid in those earlier years. ${ }^{158}$ If no taxable income in the prior three years exists, the loss may be carried forward for fifteen years. ${ }^{159}$ Because the loss is not carried forward with interest, the value of the loss carryforward decreases with the passage of time and after fifteen years it becomes zero. Creation of a neutral income tax requires that this asymmetry in taxation of income and losses be removed. ${ }^{160}$ Removal could be easily accomplished by allowing immediate refunds or loss carryforwards indefinitely with interest.

The addition of a neutral investment incentive to the income tax, such as some type of first-year deduction of a percentage of the purchase price, would be valuable only to taxpayers who have taxable income against which to offset the deduction. At least two types of taxpayers, identified by Warren and Auerbach, do not have such income. ${ }^{161}$ First, start-up companies frequently have losses in the first years of operation and profits thereafter, so that the investment incentive in the early years will be less valuable to them than to companies with taxable income. The incentive can be made neutral if the start-up company is permitted to carry forward losses indefinitely with interest to compensate for the passage of time. ${ }^{162}$ Second, so-called "loss" companies may have historical attributes such as loss carryforwards and credits from prior years that make them effectively tax-exempt for the foreseeable future. Since the purpose of a neutral investment incentive is to reduce the effective tax rates on capital income but not to less than zero, these loss companies already face a zero rate on capital income for the foreseeable future and do not need any additional investment incentive to lower their effective tax rates. ${ }^{163}$

157. For a discussion of the conflict between equity and efficiency goals, see, for example, Bittker, Equity, Efficiency, and Income Tax Theory: Do Misallocations Drive Out Inequities?, 16 SAN DiEco L. REv. 735 (1979). Some analysts argue that the basis for the criticism illustrated by Example 5 is unsound in any event because taxpayers with savings and those without are in fact different for purposes of the income tax, so that no inequity results from the interest tracing rules. See, e.g., McIntyre, supra note 154 , at 774-77.

158. I.R.C. \& 172(a), (b)(1)(A) (Lawyers Co-op. 1984 \& Supp. 1985).

159. Id. \& $172(\mathrm{a}),(\mathrm{b})(1)(\mathrm{B})$.

160. See, e.g., Auerbach, The Dynamics of Tax Asymmetries (NBER Working Paper No. 1152, 1983).

161. See Warren \& Auerbach, Transferability of Tax Incentives and the Fiction of Safe Harbor Leasing, 95

HARV. L. REv. 1752, 1757-58 (1982).

162. See id. at 1758-60.

163. See id. at 1760-61. 
As Warren and Auerbach have discussed, if the investment incentive were viewed by Congress as a subsidy operating through the tax return for certain tax-favored assets, therefore different in structure from a neutral investment incentive, it is arguably not necessary to worry about limiting the availability of the interest deduction for debt-financed investment in the tax-favored assets. ${ }^{164}$ Also, the subsidy should be made available not only to companies with taxable income but also to start-up and loss companies through some tax mechanism. ${ }^{165}$ The mechanism adopted in 1981, "safe-harbor" leasing, is inadequate to transfer the correct amount of subsidy to start-up and loss companies. ${ }^{166}$ A transferability technique is not necessary in the context of a neutral investment incentive applied to all assets, with interest income and deductions calibrated to be reduced relative to the degree of the incentive, and with the lower limit of a zero tax rate on capital income.

\section{E. Inflation}

The income tax base must be indexed for inflation to yield neutral taxation of capital income. Indexed items should include inventory, depreciation, debt, and capital gains and losses. Otherwise, FIFO inventory accounting, historic depreciation, and no indexation of interest, gains, and losses will influence both the relative yield of assets of varying durability and the aftertax real return received by savers. Under a graduated tax rate structure, without indexation, taxpayers in higher brackets will borrow to purchase real assets while low bracket taxpayers will provide the loans. Thus, inflation creates distortion both in capital allocation and in portfolio choice.

If all creditors and debtors were taxed at the same flat rate and if nominal interest rates were sufficiently flexible to maintain the same after-tax rates of return regardless of the inflation rate, it would be necessary to index only inventory and depreciation (to measure business income correctly), along with capital gains and losses. ${ }^{167}$ With graduated rates, however, arbitrage opportunities and portfolio bias exist unless interest is also indexed. In contrast, under the consumption tax, where investment in assets is expensed and interest receipts and expenses are excluded from the tax base, ${ }^{168}$ no inflation adjustment is necessary.

In the following discussion, items (1) and (2) focus on depreciation and interest indexation. Item (3) discusses capital assets indexation alone. Inventory indexation is omitted. ${ }^{169}$

164. Id. at 1757 .

165. Id. at 1759-61.

166. Id. at 1753 .

167. See, e.g., Aaron, Inflation and the Income Tax: An Introduction, in Inflation and the Income Tax 31 (H. Aaron ed. 1976); Bradford, supra note 124, at 37. For a discussion of the interaction of inflation and interest rates, see infra text accompanying notes 196-201.

168. This statement is the yield-exemption form of the consumption tax, but the same result would occur under the cash-flow consumption tax. For a discussion of the alternative treatment of loans, see supra text accompanying note 139.

169. For a discussion of inflation adjustments for inventory, see, for example, Cong. Budget Office, supra note 103, at 96; V. Tanzi, Inflation and the Personal Income Tax 68-69 (1980). 
1. Equity-Financed Investment in Depreciable Property. Example 6 illustrates the necessary index adjustment for economic depreciation based on historical cost of assets. ${ }^{170}$

Example 6. Hulten and Wykoff have shown that economic depreciation is typically similar to depreciation calculated by a declining balance method. ${ }^{171}$ Accordingly, assume that Asset $Y$ is purchased for $\$ 100$ and that its economic depreciation rate is $10 \%$. Also assume that the annual inflation rate is $10 \%$. Table 13 sets forth the declining balance depreciation for Asset $Y$ at zero inflation and at $10 \%$ inflation with indexation.

\section{TABLE 13}

\section{Depreciation of $\$ 100$ Asset with Economic Depreciation RATE OF $10 \%$}

\begin{tabular}{|c|c|c|c|c|c|c|c|}
\hline \multirow{2}{*}{$\frac{\text { Year }}{1}$} & \multicolumn{3}{|c|}{ Zero Inflation Rate } & \multicolumn{4}{|c|}{$10 \%$ Inflation Rate } \\
\hline & $0.10 \times$ & $100.0=$ & 10.00 & $(0.10 \times$ & $100)$ & $(1.10)=$ & $\$ 11.00$ \\
\hline 2 & $0.10 \times$ & $90.0=$ & 9.00 & $(0.10 \times$ & $90)$ & $(1.21)=$ & 10.89 \\
\hline 3 & $0.10 \times$ & $81.0=$ & 8.10 & $(0.10 \times$ & $81)$ & $(1.33)=$ & 10.77 \\
\hline $\begin{array}{l}4 \\
\text { Etc. }\end{array}$ & $0.10 \times$ & $72.9=$ & 7.29 & $(0.10 \times$ & 72.9) & $(1.46)=$ & 10.64 \\
\hline
\end{tabular}

As seen from Table 13, historic economic depreciation is adjusted upward by an inflation index reflecting the $10 \%$ annual inflation rate. Alternatively, the depreciation base can be adjusted by the inflation index and then the depreciation rate can be applied to the inflation-adjusted basis. The results are identical. If the Harberger investment incentive ${ }^{172}$ were adopted, indexation would apply to the portion of the purchase price subject to economic depreciation. The expensed portion of the price would be taxed equivalently to the consumption tax and therefore would require no indexation since it is inflation neutral.

A discussion of the choice of index is beyond the scope of this paper. Yet, it should be noted that writers who have discussed an inflation adjustment frequently mention a general price index rather than a specific price index for the particular asset being depreciated. ${ }^{173}$ Application of the general price index means that calculation of the income tax base takes into account the extent to which the general purchasing power of the taxpayer is maintained, not the taxpayer's purchasing power with respect to the actual capital utilized.

170. For a discussion of inflation adjustments for depreciation, see, for example, CoNG. BUDGET OfFice, supra note 103, at 92-96; V. TANZI, supra note 169, at 64-68; Aaron, supra note 167, at 11-12.

171. See supra text accompanying notes $110-12$.

172. See supra text accompanying notes $136-38$.

173. See, e.g., V. TANzI, supra note 169, at 70-71; Aaron, supra note 167, at 15-16. Steuerle has shown that in the absence of accrual taxation for all changes in values of assets, depreciation based on replacement cost is a worse measurement of income than is depreciation adjusted for general price level changes. E. Steuerle, Adjusting Depreciation for Price Changes (OTA Paper 37 , 1979). 
This distinction would be reflected if Asset $Y$ were sold. Assume that the specific price change for Asset $Y$ in Year One was $15 \%$. The replacement value of a new Asset $Y$ at the end of Year One would be $\$ 115(\$ 100 \times 1.15)$, and the replacement value of a one-year-old Asset $Y$ at the end of Year One would be $\$ 103.50$. Asset $Y$ increased in value by $\$ 15$ but decreased in value due to aging by $\$ 11.50$ (10\% depreciation rate times $\$ 115)$ for a net replacement value of $\$ 103.50$. If the change in general price level of $10 \%$ determines the depreciation deduction for Asset $Y$, the indexed adjusted basis is $\$ 99$ ( $\$ 110$ indexed adjusted basis less depreciation deduction of $\$ 11)$. The gain on the sale of Asset $Y$ is then $\$ 4.50$, the amount realized of $\$ 103.50$ less the indexed adjusted basis of $\$ 99$.

In 1980, Auerbach and Jorgenson suggested an alternative indexation method for depreciation on the basis that it would be easier to administer than the annual, ex post inflation, adjustment system described above. ${ }^{174}$ It did not receive substantial political attention as an alternative to ACRS since neither the Reagan Administration nor the business community supported it. Auerbach and Jorgenson proposed that depreciable business assets be placed into thirty-five categories, that the present value of the economic depreciation of each category of asset be measured applying a real discount rate, and that each purchaser of an asset be allowed to deduct the present value of that economic depreciation as an expense in the year the asset is acquired. The capital recovery allowance can be invariant with the rate of inflation because the allowance is taken for tax purposes in the same year the asset is acquired. Moreover, the effective tax rate on the income produced from all assets will be near the statutory rate, assuming that measurement errors of the capital recovery allowances due to imperfect measurements of economic depreciation, ${ }^{175}$ and of the discount rate, are small. ${ }^{176}$ Table $14^{177}$ displays Jorgenson's classification of assets into thirty-five groups; Table $15^{178}$ lists the first-year capital allowance for each group.

Economists have made several observations and criticisms about the Auerbach-Jorgenson proposal. ${ }^{179}$ The first-year recovery is a measure of the present value of an asset's economic depreciation where the real discount rate is applied to the calculation. First, this calculation relies upon measurements of economic depreciation and is only as good as the estimates of economic

174. Auerbach \& Jorgenson, Inflation-Proof Depreciation of Assets, 58 HARv. Bus. Rev. 122 (1980).

175. Auerbach and Jorgenson used declining-balance depreciation based on the Hulton and Wykoff measurement of economic depreciation. For a discussion of the Hulton and Wykoff measurement, see supra text accompanying notes 109-16.

176. In their article, Auerbach and Jorgenson used a real discount rate of $4 \%$. Auerbach \& Jorgenson, supra note 174 , at 115 . Jorgenson used a real discount rate of $6 \%$, as reflected infra in Table 15 accompanying note 178 . See Jorgenson \& Sullivan, supra note 65, at 227.

177. Table 14 is taken from Jorgenson \& Sullivan, supra note 65, at 179 (Table 1).

178. Table 15 is taken from Jorgenson \& Sullivan, supra note 65, at 228 (Table 19).

179. See, e.g., Bradford, supra note 124, at 41-44; Fullerton, Lyon \& Rosen, Uncertainty, Welfare Cost and the "Adaptability" of U.S. Corporate Taxes 11-12 (NBER Working Paper No. 1239, 1983). 
TABLE 14

Asset Category

1. Furniture and fixtures

2. Fabricated metal products

3. Engines and turbines

4. Tractors

5. Agricultural machinery

6. Construction machinery

7. Mining and oilfield machinery

8. Metalworking machinery

9. Special industry machinery

10. General industrial equipment

11. Office, computing, and accounting machinery

12. Service industry machinery

13. Electrical machinery

14. Trucks, buses, and trailors

15. Autos

16. Aircraft

17. Ships and boats
18. Railroad equipment

19. Instruments

20. Other equipment

21. Industrial buildings

22. Commercial buildings

23. Religious buildings

24. Educational buildings

25. Hospital buildings

26. Other nonfarm buildings

27. Railroads

28. Telephone and telegraph facilities

29. Electric light and power

30. Gas

31. Other public utilities

32. Farm

33. Mining, exploration, shafts and wells

34. Other nonbuilding facilities

35. Residential

depreciation used in the calculation. ${ }^{180}$ Second, knowledge of the individual taxpayer's marginal rate and the relationship between nominal interest rates and inflation is necessary for the first-year recovery to be invariant with inflation. Because it is not practical to calculate tax depreciation tables based on every marginal tax rate under the current graduated rate structure, the Auerbach-Jorgenson proposal used a single flat rate, such as the corporate tax rate of $46 \%$. Jorgenson argues that use of a single rate is accurate enough because the marginal corporate tax rate for most capital in the corporate sector is $46 \%$ and that the personal tax rate for individuals with property income is also very flat. ${ }^{181}$ If the allowance is pegged at $46 \%$, for example, the deduction will be too large for lower bracket taxpayers and will favor their investment in real assets with short durability. Alternatively, the deduction will be too small for investors with marginal tax brackets above $46 \%$. The relationship between nominal interest rates and inflation is uncertain. ${ }^{182}$ If interest is indexed, uncertainty about future inflation does not affect after-tax real rates of return under the graduated tax structure so that if that rate is known and is constant, the Auerbach-Jorgenson proposal can be invariant with inflation. Auerbach-Jorgenson used a $4 \%$ real rate of interest discount rate, but the real rate of interest may not be constant. If interest is not indexed, then the real rate of return cannot be known in advance and only ex post indexation will be invariant with inflation. ${ }^{183}$

180. For a discussion of available empirical evidence with respect to depreciation, see supra text accompanying notes 109-16.

181. Comments by Dale W. Jorgenson, in Depreciation, Inflation and the Taxation of Income From Capital 52 (C. Hulton ed. 1981).

182. See infra text accompanying notes 197-201.

183. For a discussion of the relationship of nominal interest rates, inflation, and the graduated tax structure, see infra text accompanying notes 197-201. 
TABLE 15

First-Year Capital Recovery System

\begin{tabular}{|c|c|c|c|c|}
\hline \multirow[b]{2}{*}{ Asset } & \multirow{2}{*}{$\begin{array}{l}\text { First-Year } \\
\text { Allowance }\end{array}$} & \multicolumn{3}{|c|}{$\begin{array}{l}\text { Investment Tax Credit at } \\
\text { Various Effective Tax Rates }\end{array}$} \\
\hline & & Zero & 0.23 & $\overline{0.46}$ \\
\hline 1 & 0.645 & 0.16 & 0.08 & 0.00 \\
\hline 2 & 0.602 & 0.18 & 0.09 & 0.00 \\
\hline 3 & 0.565 & 0.20 & 0.10 & 0.00 \\
\hline 4 & 0.729 & 0.12 & 0.06 & 0.00 \\
\hline 5 & 0.616 & 0.18 & 0.09 & 0.00 \\
\hline 6 & 0.740 & 0.12 & 0.06 & 0.00 \\
\hline 7 & 0.731 & 0.12 & 0.06 & 0.00 \\
\hline 8 & 0.669 & 0.15 & 0.08 & 0.00 \\
\hline 9 & 0.630 & 0.17 & 0.09 & 0.00 \\
\hline 10 & 0.669 & 0.15 & 0.08 & 0.00 \\
\hline 11 & 0.818 & 0.08 & 0.04 & 0.00 \\
\hline 12 & 0.731 & 0.12 & 0.06 & 0.00 \\
\hline 13 & 0.660 & 0.16 & 0.08 & 0.00 \\
\hline 14 & 0.807 & 0.09 & 0.04 & 0.00 \\
\hline 15 & 0.846 & 0.07 & 0.04 & 0.00 \\
\hline 16 & 0.752 & 0.11 & 0.06 & 0.00 \\
\hline 17 & 0.553 & 0.21 & 0.10 & 0.00 \\
\hline 18 & 0.521 & 0.22 & 0.11 & 0.00 \\
\hline 19 & 0.712 & 0.13 & 0.07 & 0.00 \\
\hline 20 & 0.712 & 0.13 & 0.07 & 0.00 \\
\hline 21 & 0.373 & 0.29 & 0.14 & 0.00 \\
\hline 22 & 0.290 & 0.33 & 0.16 & 0.00 \\
\hline 23 & 0.237 & 0.35 & 0.18 & 0.00 \\
\hline 24 & 0.237 & 0.35 & 0.18 & 0.00 \\
\hline 25 & 0.278 & 0.33 & 0.17 & 0.00 \\
\hline 26 & 0.428 & 0.26 & 0.13 & 0.00 \\
\hline 27 & 0.225 & 0.36 & 0.18 & 0.00 \\
\hline 28 & 0.335 & 0.30 & 0.15 & 0.00 \\
\hline 29 & 0.331 & 0.31 & 0.15 & 0.00 \\
\hline 30 & 0.331 & 0.31 & 0.15 & 0.00 \\
\hline 31 & 0.426 & 0.26 & 0.13 & 0.00 \\
\hline 32 & 0.281 & 0.33 & 0.13 & 0.00 \\
\hline 33 & 0.482 & 0.24 & 0.17 & 0.00 \\
\hline 34 & 0.324 & 0.31 & 0.12 & 0.00 \\
\hline 35 & 0.173 & 0.38 & 0.19 & 0.00 \\
\hline
\end{tabular}

Thus, the Auerbach-Jorgenson proposal is not an absolutely accurate substitute for ex post indexation since, for practical reasons, it is based on a single marginal tax rate and a single after-tax rate of return, neither of which will be accurate for all taxpayers at all times. Nevertheless, Jorgenson argues that their method is accurate enough to be an adequate substitute for ex post inflation adjustments, particularly when administrative considerations are taken into account. ${ }^{184}$

Since the effect of the Auerbach-Jorgenson first-year recovery deduction is equivalent to deducting economic depreciation, the effective tax rate resulting

184. See Comments by Jorgenson, supra note 181, at 53-55. 
from the deduction would be approximately the statutory rate for all equityfinanced investments. If Congress desires to lower effective tax rates below the statutory rate on business investment, the Auerbach-Jorgenson proposal can be combined with a neutral investment incentive. The proposal could be combined, for example, with the Harberger incentive. ${ }^{185}$ If $10 \%$ of the purchase price of an asset is expensed when purchased, then the other $90 \%$ of the price could be subject to the Auerbach-Jorgenson deduction. ${ }^{186}$ Brown has suggested an investment tax credit method to complement the AuerbachJorgenson proposal. ${ }^{187}$ A neutral credit incentive is proportional to the difference between the cost of an asset and the Auerbach-Jorgenson first-year deduction. The proportion can be varied between zero and the statutory rate. Since the credit is also taken in the year the asset is purchased, it is invariant with inflation. The last three columns of Table 15 display the appropriate credit to achieve effective tax rates on income produced from the various classes of assets of $0 \%, 23 \%$, and the statutory corporate tax rate of $46 \%{ }^{188}$

Thus, two alternative methods of indexation have been offered by analysts-ex post indexation of the depreciation base and ex ante depreciation in the form of a first-year deduction equal to the present value of future depreciation. The ex ante deduction is a close, but not exact, substitute for ex post indexation. Either method can easily be combined with the Harberger investment incentive, and the ex ante indexation combined with the Brown calibrated investment tax credit. Ex ante indexation is not as accurate as ex post indexation, but it would be much easier to administer since it requires only a tax table such as Table 15 and is handled by a single deduction in the year of purchase. One political problem with the enactment of ex ante indexation is the cash-flow effect on the budget. The present value of the two methods to the government are the same, to the extent that ex ante indexation is an equivalent substitute for ex post indexation, but the large first-year ex ante deduction involves immediately larger government revenue losses than the equivalent ex post indexation. The adoption of an ex ante deduction would likely be accompanied by a transition rule to phase in the deduction over a few years. Also, capital allowance recovery systems and investment incentives which are "front-ended" in this fashion will not be neutral with respect to all business investment unless the net operating loss rules are modified to permit carryover of losses with interest or immediate refunds. ${ }^{189}$

185. For a discussion of the Harberger incentive, see supra text accompanying notes 136-38.

186. Presumably the actual marginal tax rate of the taxpayer would be used to determine the proportion of interest receipts and expenses to be included in the tax base, in accordance with the suggestion of Bradford discussed supra in text accompanying notes 148-49, even though a single rate was used in determining the amount of the Auerbach-Jorgenson deduction.

187. Brown, The "Net" Versus the "Gross" Investment Tax Credit, in Depreciation, Inflation and the Taxation of InCome from Capital 133 (C. Hulton ed. 1981).

188. See supra text accompanying note 178.

189. See supra text accompanying notes 158-67. 
2. Debt-Financed Investment in Depreciable Property. The previous section discussed the indexation of the depreciation deduction when real assets are equity-financed. What must be done when real assets are debt-financed? Ideally, to maintain a neutral income tax, the entire tax base would be indexed, including all indebtedness. Different methods of indexation of interest bearing assets and liabilities are possible. ${ }^{190}$ For example, assume that $B$ has borrowed $\$ 1,000$ from $C$ at $15 \%$ interest and the inflation rate is $10 \%$. $B$ reports a nominal interest deduction of $\$ 150$, but with indexation also reports the gain of $\$ 100(\$ 1,000$ loan principal $\times 10 \%$ inflation rate) resulting from the reduction in value of the nominal face value amount of the loan. This method represents partial accrual of gains and losses, due to changes in general price levels, but not full accrual, which incorporates relative price changes as well. Alternatively, $B$ could report the nominal gain on only the amount of the loan amortized during the accounting period. For example, if $B$ amortized $\$ 100$ of the loan principal, the reported nominal gain would be $\$ 10$ (\$100 repayment $\times 10 \%$ inflation rate). This method represents realization accounting. $C$ 's tax reporting would mirror that of $B$. $C$ reports nominal interest income of $\$ 150$ and either a loss of $\$ 100$ resulting from the reduction in value of the nominal face amount of the entire loan or a loss of $\$ 10$, reflecting the loss only with respect to the $\$ 100$ repayment of loan principal.

Full indexation of the tax base is the ideal handling of income measurement when price levels are not stable, but many have objected to full indexation as administratively impractical. ${ }^{191}$ Others, including this writer, do not share this view and believe that full indexation is administratively achievable. ${ }^{192}$ Removal of computational burdens currently utilized to accomplish ad hoc inflation adjustments would offset similar burdens caused by indexation.

In response to those who raise objections of administrative infeasibility (and to those who use these objections to argue for abandoning the income tax in favor of the consumption tax), some economists have offered partial indexation schemes. Two are discussed here. The first is indexation of depreciation only for equity-financed capital. The second is indexation only of depreciation, whether it is equity- or debt-financed. A third, indexation of capital gains, is discussed below in item (3).

190. For a discussion of the indexation of interest receipts and expenditures, see, for example, $V$. TANZI, supra note 169, at 51-59; Aaron, supra note 167, at 8-10.

191. See, e.g., INSTITUTE FOR FISCAL SERVICEs, supra note 139, at 147. For a discussion of foreign experience with indexation, see, for example, INST. FOR INT'L ECON., INFLATION AND INDEXATION: Argentina, Brazil, \& Israel (1985); Lent, Adjusting Taxable Profits for Inflation: The Foreign Experience, in Inflation and the Income Tax 195 (H. Aaron ed. 1976).

192. See, however, the discussion infra accompanying notes $241-44$, concerning the Treasury Department's interest indexation proposal, which takes into account administrative problems in designing the indexation method. 
The following example, based on Example 6 in the previous section, illustrates the reasoning for indexing only equity-financed depreciation. ${ }^{193}$ Example 7. Assume that the depreciable Asset $Y$ costs $\$ 100$ and is $100 \%$ debt-financed. Assume also that the depreciation rate is $10 \%$, that a $5 \%$ interest rate is paid on the loan, and that $10 \%$ of the outstanding loan principal is amortized annually. Note that the loan amortization rate is identical to the depreciation rate. Assume alternatively that the inflation rate is $10 \%$, that the nominal interest rate is $15 \%$, and that the tax base is indexed. Table 16 shows depreciation and interest expenses when the inflation rate is zero and $10 \%$ and the tax base is indexed. Rather than indexing the outstanding principal amount of the loan, only the repayment of the loan principal made each year is indexed.

\section{TABLE 16}

DEPRECIATION AND INTEREST EXPENSE OF $\$ 100$ AsSET, $100 \%$ Debt-Financed, Depreciation Rate of $10 \%$, AND INDEXATION OF TAX BASE

\begin{tabular}{llcc}
\hline Year & & $\begin{array}{c}\text { Zero Inflation } \\
\text { Rate }\end{array}$ & $\begin{array}{c}10 \% \\
\text { Inflation Rate }\end{array}$ \\
\hline 1 & Depreciation & $10.0^{\mathrm{a}}$ & $11.0^{\mathrm{c}}$ \\
& Interest & $5.0^{\mathrm{b}}$ & $15.0^{\mathrm{b}}$ \\
& $\begin{array}{l}\text { Gain on loan } \\
\text { principal }\end{array}$ & & \\
& amortization & - & $1.0^{\mathrm{d}}$ \\
& Depreciation & $9.0^{\mathrm{a}}$ & $10.89^{\mathrm{c}}$ \\
& Interest & $4.5^{\mathrm{b}}$ & $13.5^{\mathrm{b}}$ \\
& Gain on loan & & \\
& principal & & $1.89^{\mathrm{d}}$ \\
& amortization & - & $10.77^{\mathrm{c}}$ \\
& Depreciation & $8.1^{\mathrm{a}}$ & $12.15^{\mathrm{b}}$ \\
& Interest & $4.05^{\mathrm{b}}$ & \\
& Gain on loan & & $2.67^{\mathrm{d}}$ \\
\hline
\end{tabular}

a. Depreciation Rate $\times$ Undepreciated Tax Base.

b. Interest Rate $\times$ Unamortized Loan Balance.

c. (Depreciation Rate $\times$ Undepreciated Depreciation Base) (Inflation Adjustment).

d. (Loan Amortization $\times$ Inflation Adjustment) - (Loan Amortization).

In Example 7, the increase in the depreciation expense deduction due to indexation exactly equals the income from the indexation of the loan repayment. The net effect, therefore, is the same as if no indexation of the tax base were made. The relationship between indexation of depreciation and debt has resulted in the suggestion that depreciation should be indexed only for the portion that is equity-financed, since the index adjustment for debt-

193. For a description and discussion of this partial indexation method, see V. TANZI, supra note 169 , at 66-68. 
financed depreciation and the loan amortization payment are exactly offsetting where the rate of depreciation and debt repayment are identical. ${ }^{194}$

Obvious criticisms of this partial indexation scheme exist. ${ }^{195}$ First, the condition that the depreciation rate and the loan amortization rate be identical is so unlikely to appear in real transactions that the adoption of this partial indexation method would yield inaccurate results in most transactions. Second, this method requires some set of tracing rules to determine what annual percentage of depreciable assets are debt-financed. Third, it is not clear whether the promoters of this method intend to index the creditor's side of the debt. If not, then it retains serious distortions in the tax base. For example, this system works if the firm is a net debtor; however, if the firm is a net creditor, its net interest receipts need to be corrected for inflation. On the other hand, if the rest of the tax base is to be indexed anyway, then it is easier to index each part of the tax base separately rather than to index a portion of the tax base (here debt and depreciation) by a process based on offsetting factors (which are in fact unlikely to be equivalent offsets). Thus, this partial indexation scheme raises practical problems of calculating the percentage of depreciable assets which are debt-financed, and the scheme retains distortions in the income tax since it is not an indexation system of the entire tax base.

Alternatively, economists have argued that indexation of only depreciation adequately substitutes for indexation of the entire tax base. ${ }^{196}$ An understanding of this suggestion requires analysis of the interaction of nominal interest rates, inflation, and the income tax. ${ }^{197}$

Ignoring income taxes, Fisher suggested ${ }^{198}$ that:

$$
i=i^{*}+g
$$

where $i=$ nominal interest rate, $i^{*}=$ real interest rate, and $g=$ the inflation rate. In other words, the nominal interest rate increases point-for-point with inflation. Darby, Feldstein, and Tanzi later pointed out that when inflation is anticipated, lenders will demand a premium to cover their expected loss attributable both to inflation (inflationary loss on the loan principal) and the fact that the income tax is not indexed for inflation. ${ }^{199}$ Borrowers will be willing to pay the premium because the nominal interest expense is deducted

194. See, e.g., H. Hofstra, An Inflation-Adjusted Tax System, A Summary of Dutch Report 40 (1978); W. Fellner, K. Clarkson \& J. Moore, Correcting Taxes for Inflatton (1975); Aaron, supra note 167, at 31; Davidson \& Weil, Inflation Accounting: Implications of the FASB Proposal, in InFLation and the Income Tax 119-20 (H. Aaron ed. 1976).

195. For a critique of this partial indexation system, see Tideman \& Tucker, The Tax Treatment of Business Profits under Inflationary Conditions, in InfLation aNd THE INCOME TAX 59-60 (H. Aaron ed. 1976).

196. See, e.g., Aaron, supra note 167, at 29.

197. For a detailed summary of the analysis of the interaction of nominal interest rates, inflation, and the income tax, see INTERnational Monetary Fund, TaXation, Inflation and INTEREST Rates 15-28, 69-98 (V. Tanzi ed. 1984) [hereinafter cited as Taxation, Inflation and InTEREST Rates].

198. I. Fisher, ThE Theory OF INTEREST (1930).

199. Darby, The Financial and Tax Effects of Monetary Policy on Interest Rates, 13 Econ. InquIRY 226 (1976); Feldstein, Inflation, Income Taxes, and the Rate of Interest: $A$ Theoretical Analysis, 66 AM. ECON. Rev. 809 (1976); Tanzi, Inflation, Indexation and Interest Income Taxation, Q. REv. No. 116, 64 (Banco Nazionale del Lavoro (Rome) 1976). 
in a nonindexed income tax. Accordingly, if all lenders and borrowers were to face the same marginal tax rate, $m$, the nominal interest rate, $i$, must adjust with inflation in accordance with the following equation:

$$
i=i^{*}+g /(1-m)
$$

With this adjustment to $i$, after-tax rates of return are unaffected by inflation when the income tax is not indexed. For example, assume that $i^{*}=5 \%, \mathrm{~g}=$ $10 \%$, and $m=50 \%$ for both lenders and borrowers. Then $i=25 \%$ :

$$
i=5 \%+10 \% /(1-0.50)
$$

If the tax base were indexed, however, the excess of $i$ over $i *$ is not taxed and is not deductible so that $i=i^{*}+g$, or $15 \%$ in this example. Thus, economists argue, if this interest adjustment occurs, borrowers and lenders are in the same after-tax position whether or not the interest is indexed.

As seen in the earlier discussion of partial indexation of debt-financed depreciation, where borrowed funds are invested in depreciable assets, the nominal gain on the indebtedness is offset by the nominal loss on the historic depreciation. If $i$ adjusts in accordance with equation (2), the nominal gain on the loan is eliminated and the borrower who invests in depreciable property will experience a nominal loss on the historic depreciation, which is not offset by the existence of the nominal gain since it has been eliminated. Accordingly, if interest is not indexed and $i$ adjusts in accordance with equation (2), only depreciation need be indexed.

Obviously, this partial indexation will not substitute perfectly for indexation of the entire tax base, because the various conditions listed above for the adjustment of $i$ do not exist. First, partial indexation requires that everyone anticipate the same rate of inflation, unless loans themselves are indexed ex post. Second, partial indexation requires that all lenders and borrowers have the same marginal tax rate, a requirement obviously not met in an income tax with graduated brackets. Where the income tax is not indexed, borrowers will be in the upper tax brackets and lenders will be in the lower brackets and the nominal interest rate will tend toward equation (2) but it will not fully adjust to that point. Third, factors other than the income tax affect nominal rates; thus, equation (2) is too simplified and does not take into account all factors influencing the equilibrium point for $i .{ }^{200}$ Empirical evidence suggests that nominal interest rates in the United States are in fact closer to the sum of the real interest rate plus inflation. ${ }^{201}$ Thus, indexation of depreciation alone is not a perfect substitute for full indexation. Economists argue, however, that indexation of depreciation is better than no indexation at all and is superior to ad hoc adjustments like accelerated depreciation. ${ }^{202}$ They point to the fact

200. For a discussion of the effects of nontax factors on the nominal interest rate, see TAXATION, INFLATION AND INTEREST RATES, supra note 197, at 16-22.

201. For a summary of empirical research on the interaction of interest rates, inflation, and income taxation, see TAXATION, InfLATION AND INTEREST RATES, supra note 197, at 23-26; Katz, Inflation, Taxation, and the Rate of Interest in Eight Industrial Countries, 1961-82, in id. at 172.

202. See supra note 196. 
that with the election of LIFO accounting, inventory can be indexed effectively. To be sure, all lenders and borrowers are not in the same marginal tax bracket, but nominal interest rates will tend toward the equilibrium expressed by equation (2), and they may reach an equilibrium point equivalent to that which would be achieved if interest bearing assets were partially indexed. Accordingly, the only serious business income input which is not indexed is depreciation expense. It is not administratively difficult to index depreciation, as shown in the previous section. Tax depreciation based upon economic depreciation indexed for inflation is substantially more neutral than using ad hoc accelerated depreciation methods for tax depreciation.

3. Inflation Adjustment for Capital Assets. Under an ideal income tax, unrealized gains and losses would be accrued and taxed each accounting period. Such annual changes in value would be indexed for inflation so that only real gains and losses would be taxed. The importance of such an index, however, would be substantially less than under the current income tax, which defers measurement of gains and losses for tax purposes until an event of realization. It has been suggested at various times that capital assets alone be indexed, ${ }^{203}$ and this suggestion incorporates the assumption that the current realization doctrine would remain a part of the income tax.

This partial indexation system raises several problems. First, the system discriminates among assets, since not all assets yield capital gains and losses. For example, interest-bearing savings accounts and land sold as inventory do not yield capital gains and losses and thus would not receive the benefits of indexation. Accordingly, the partial indexation of capital assets is nonneutral with respect to type of investment. Second, the scheme, as typically proposed, continues to measure depreciation with respect to historical basis. The depreciated historical basis is indexed only when the asset is sold. Accordingly, the depreciation deduction is not indexed for inflation, but only real gains or losses on the sale of the depreciable asset are included in the tax base. ${ }^{204}$ This dichotomy creates an incentive to sell depreciable assets in order to obtain the benefit of the inflation adjustment. Third, indexation of capital assets without indexation of debt used to purchase the asset yielding the capital gain would give the taxpayer the advantage of indexing the basis of the asset (thereby decreasing the gain from the sale) without indexing the debt by which the asset was purchased (thereby failing to add the gain with respect to the debt to the tax base). The result is a mismatch of real gains and

203. For a discussion of indexation of capital assets, see, for example, Dep't of Finance, Canada, A Review of the Taxation of Capital Gains in Canada 40-45 (1980); id. Appendix II, at 57-58; Brinner, Inflation and the Definition of Taxable Personal Income, in INFLATION AND THE INCOME TAX 121 (H. Aaron ed. 1976).

204. For example, assume that Asset $Y$ is purchased for $\$ 100$, that the depreciation rate is $10 \%$, and that the inflation rate is $10 \%$. Historical depreciation would be $\$ 10$ and $\$ 9$ in Years One and Two, respectively. If Asset $Y$ were sold at the end of Year Two, the historical adjusted basis would be $\$ 81$, but it would be adjusted upward by the fraction $121 / 100$ to $\$ 98.01$. This basis is identical to the basis that would have resulted from indexation of both the depreciation expense and the gain on the sale of the asset. 
nominal interest deductions. If nominal interest rates were to adjust in accordance with the formula, $i=i^{*}+g /(1-m)$, then it would be unnecessary to index the debt. ${ }^{205}$ Empirical evidence shows, however, that nominal interest rates are likely to adjust more closely to the formula, $i=i^{*}+g$, so that the nominal interest rate will not increase enough to offset the advantage of deducting nominal interest rates. ${ }^{206}$ Thus, indexation of debt-financed capital gains will lead to arbitrage opportunities by which highbracket taxpayers borrow from low-bracket taxpayers to purchase the real assets which are indexed.

Thus, indexation of capital assets alone excludes some assets which do not yield capital gains and losses and yields mismeasurement and nonneutrality problems in the taxation of business income since it provides an inflation adjustment only for depreciable assets when they are sold and allows for mismatching of taxation of real gains with nominal interest deductions for debt-financed capital assets. To eliminate the latter problem, indexation could be limited to equity-financed capital assets, but such a limitation requires tracing rules to determine to what extent the indexed assets are debtfinanced.

4. Summary. To establish a neutral capital income system, the entire tax base must be indexed. Partial indexation systems-for example, indexation only with respect to depreciation and interest or capital assets-are not adequate substitutes. An argument can be made, however, that if full indexation of the tax base is rejected for administrative reasons, indexation of the depreciation deduction along with capital assets may be better than no indexation at all.

\section{F. Summary}

The following features must be present to establish an investment neutral income tax:

1. Tax depreciation must be based on economic depreciation that takes into account all factors affecting the asset's value, including aging and general and relative price changes. Economists Hulten and Wykoff have measured estimates of economic depreciation due to aging, and methods for inflation adjustment of depreciation exist. It is unlikely, however, that the tax base will ever include accrued gains and losses from relative price changes, and suggested proxies usually rely upon the realization doctrine for the timing of the tax; thus, the proxy is only a substitute for assets which are sold and not for those which are solely owner-utilized. Inclusion of measurement of relative price changes may be of secondary importance for depreciable assets, particularly those of short durability. Research by Bulow and Summers suggests, however, that

205. See supra text accompanying notes $199-200$.

206. See supra text accompanying note 200 . 
depreciation may be significantly understated because of the failure to take into account the risk premium associated with relative price changes.

2. Neutral investment incentives, which are easy to calculate and to administer, are available. Economic depreciation can be combined with the Harberger firstyear deduction incentive, and the Auerbach-Jorgenson first-year depreciation deduction can be combined with the Brown investment credit. A neutral investment incentive would be targeted at lowering the effective tax rate on capital from the statutory rate to some lower rate, but not less than zero, since negative tax rates yield investments which would not even be made in the absence of taxes. Any incentive proposal requires a review of the unlimited interest deduction for debt-financed investment. To prevent misallocation of capital across assets, temporal misallocation of capital, and shifts in portfolio choice, interest receipts and expenses must be calibrated to match the degree of the investment incentive which is adopted.

3. The asymmetrical treatment of investment income and losses must be eliminated. The asymmetry becomes increasingly distorting the larger the available investment incentive.

4. The tax base must be indexed for inflation, including inventory, depreciation, debt, and capital gains and losses. Indexation of capital gains and losses and depreciation is a second-best partial indexation scheme which would not eliminate all distortions from inflation. LIFO could remain available for inventory and nominal interest rates may interact with inflation and the income tax to offset part of the distortion in taxing nominal interest receipts and expenses.

This summary takes into account only the factors discussed in this section. A neutral system would also tax all accrued gains and losses and integrate the personal and corporate income taxes.

\section{IV}

How Investment Neutral Are Recent Income Tax Reform Proposals?

Recently, many bills have been introduced in Congress which would "reform" the income tax in a number of ways, including modification of the income taxation of capital. Also, in November and December 1984, the Treasury Department issued its comprehensive tax reform proposals, ${ }^{207}$ and in May 1985, President Reagan issued his comprehensive tax reform proposals ${ }^{208}$ which are a revision of the Treasury Department's original proposals. This section briefly compares and analyzes the Treasury's

207. 1 \& 2 U.S. Dep't of the Treas., Report to the President: Tax Reform for Fairness, Simplicity, and ECONOMic Growth (1984) [hereinafter Treas. RePORT].

208. The President's Tax Proposals to the Congress for Fairness, Growth, and Simplicity (1985) [hereinafter Pres. Proposals]. 
proposals, the President's proposals, and the Bradley-Gephardt ${ }^{209}$ and KempKasten ${ }^{210}$ bills, since the latter bills have received the most attention among the various congressional bills yet introduced. The purpose of the following analysis is to determine to what extent these various proposals would bring the income tax toward the neutral system discussed in Section III.

Table 17 provides an overview of the basic features of the four proposals which relate to capital income taxation. Significantly, the Bradley-Gephardt bill omits either indexation or ad hoc measures (except to the extent that depreciation deductions are accelerated) to take into account the effects of inflation. Such a system in an inflationary economy would lead to substantial distortions in the measurement of the tax base. Primary features of the Kemp-Kasten bill as originally introduced were retention of ACRS and partial indexation of only capital gains. ${ }^{211}$ In its original form, the Kemp-Kasten bill substantially mismeasured the tax base, both from the ad hoc nature of the ACRS depreciation system and from the decision to index only one part of the tax base. In contrast, the original Treasury proposal was much more carefully designed to achieve neutral taxation of capital income, and this achievement is a significant overall feature of this proposal. ${ }^{212}$ A revised form of the KempKasten bill was introduced in January $1985 . .^{213}$ It modifies the recovery allowance schedules of ACRS to make the present value of depreciation deductions, at a $3.5 \%$ real rate of return, equivalent to expensing of equity investment for each class of recovery property. ${ }^{214}$ Like the Treasury proposal, the Kemp-Kasten bill now indexes depreciation. ${ }^{215}$ Overall, the President's proposals are not as neutral as those of the Treasury. In particular, the President's proposals eliminate the Treasury's proposal to index interest income and receipts, retain the distinction in tax rates for ordinary income and capital gains, propose that an election be permitted, beginning January 1, 1991, to index the capital asset basis in lieu of applying a preferential capital gains rate, ${ }^{216}$ and provide for only a $10 \%$, rather than a $50 \%$, dividend-paid deduction. 217 A significant omission from all three proposals is taxation directly or by proxy of accrued gains and losses.

It is not necessary here to analyze in any detail the effect of each feature of each proposal. The discussion in Section III sets out the necessary

209. S. 1421, H.R. 3271, 98th Cong., 1st Sess. (1984) This bill was reintroduced without change in 1985. S. 409, H.R. 800, 99th Cong., 1 st Sess. (1985).

210. S. 2948, H.R. 6165, 98th Cong., 1st Sess. (1983). This bill was reintroduced with several changes in 1985. S. 1006, H.R. 777, 99th Cong., lst Sess. (1985).

211. H.R. 6165, supra note 210, \& 231 (capital gains), \& 301 (depreciation).

212. A study by the Congressional Research Service of the Library of Congress concluded that the Treasury's tax reform proposal would result in significant efficiency gains to the U.S. economy through more efficient reallocation of capital. J. Gravelle, Assessinc Structural Tax Revision with Macroeconomic Models: The Treasury Tax Proposals and allocation of Investment (Cong. Res. Service 1985).

213. H.R. 777, supra note 210.

214. Id. \& 301. See BNA Daily Tax Rep. G3-G4 (Jan. 25, 1985).

215. H.R. 777, supra note $210, \$ 301$.

216. Pres. Proposals, supra note 208, at 168-69.

217. Id. at $122-23$. 
TABLE 17

Summary and Comparison of Provisions Related

to Taxation of Capital Income

\begin{tabular}{|c|c|c|c|c|}
\hline Feature & $\begin{array}{l}\text { Treasury } \\
\text { Proposal } \\
\end{array}$ & $\begin{array}{c}\text { President's } \\
\text { Proposal } \\
\end{array}$ & $\begin{array}{l}\text { Bradley- } \\
\text { Gephardt }\end{array}$ & $\begin{array}{l}\text { Kemp- } \\
\text { Kasten } \\
\end{array}$ \\
\hline Depreciation & $\begin{array}{c}\text { Economic } \\
\text { Depreciation }\end{array}$ & $\begin{array}{l}\text { Economic } \\
\text { Depreciation } \\
\text { Plus Rate for } \\
\text { Investment } \\
\text { Incentive }\end{array}$ & $\begin{array}{l}\text { Modified } \\
\text { ADR }\end{array}$ & $\begin{array}{l}\text { Modified } \\
\text { ACRS }\end{array}$ \\
\hline Investment Tax Credit & No & No & No & No \\
\hline $\begin{array}{l}\text { Indexation } \\
\text { Depreciation } \\
\text { Inventory } \\
\text { Interest } \\
\text { Capital Assets }\end{array}$ & $\begin{array}{l}\text { Yes } \\
\text { Yes } \\
\text { Yes } \\
\text { Yes }\end{array}$ & $\begin{array}{c}\text { Yes } \\
\text { Yes } \\
\text { No } \\
\text { Electionb }\end{array}$ & $\begin{array}{l}\text { No } \\
\text { No } \\
\text { No } \\
\text { No }\end{array}$ & $\begin{array}{l}\text { Yes } \\
\text { No } \\
\text { No } \\
\text { Electionc }\end{array}$ \\
\hline $\begin{array}{l}\text { Limitation on } \\
\text { Interest } \\
\text { Deduction }\end{array}$ & Yes $^{d}$ & Yes $^{d}$ & Yese & Yes $^{f}$ \\
\hline $\begin{array}{l}\text { Distinction in Tax } \\
\text { Rates for Ordinary } \\
\text { Income/Capital Gains }\end{array}$ & No & Yes ${ }^{b}$ & No & Yes $^{c}$ \\
\hline $\begin{array}{l}\text { Accrual of Gains } \\
\text { and losses } \\
\text { Integration }\end{array}$ & $\begin{array}{c}\text { No } \\
\text { Partialg }\end{array}$ & $\begin{array}{c}\text { No } \\
\text { Partialh }\end{array}$ & $\begin{array}{l}\text { No } \\
\text { No }\end{array}$ & $\begin{array}{l}\text { No } \\
\text { No }\end{array}$ \\
\hline
\end{tabular}

a. Applies the following proxy: interest receipts and expenses are reduced by a fraction, the numerator of which is the inflation rate and the denominator of which is the inflation rate plus an assumed $6 \%$ real interest rate.

b. The present exclusion for net capital gain is reduced from $60 \%$ to $50 \%$. Noncorporate taxpayers have the option to index the basis of capital assets in lieu of the $50 \%$ exclusion. The marginal ordinary income and capital gains rates for noncorporate taxpayers are $35 \%$ and $17.5 \%$, respectively.

c. Individuals and corporations have the option to index the basis of capital assets and apply ordinary income rates, or not to index the basis of capital assets and apply special capital gains rates. The marginal ordinary income and capital gain rates for individuals are $24 \%$ and $14.4 \%$ (because $40 \%$ of capital gain is excluded from the tax base), respectively, and for corporations are $35 \%$ and $20 \%$, respectively.

d. Allows home mortgage interest deduction. All other nonbusiness interest expense deducted to the extent of sum of investment income and income from limited partnerships and $S$ corporations plus $\$ 5,000$.

e. For purposes of computing the tax base taxed at a $14 \%$ rate, allows itemized deductions for home mortgage interest and for other nonbusiness interest expense to extent of investment income and income from limited partnerships, $S$ corporations, and certain net leases. For purposes of computing surtaxes, allows nonbusiness interest expense (other than home mortgage interest) to extent of investment income and income from limited partnerships, $S$ corporations and certain net leases. Accordingly, the value of the home mortgage interest deduction is limited to the nominal rate of $14 \%$. It is also limited to indebtedness to acquire, construct, or substantially rehabilitate the home.

f. Allows home mortgage interest deduction on indebtedness to acquire, construct, or rehabilitate any residential property. Retains $\$ 163(\mathrm{~d})$, disallows interest with respect to consumer debt except for residential and educational loans.

g. Allows corporation to deduct $50 \%$ of dividends paid from corporate profits which incurred full corporate tax.

h. Allows corporation to deduct $10 \%$ of dividends paid from corporate profits which incurred full corporate tax. 
background for the reader to grasp quickly from Table 17 the degree to which neutral taxation of capital income is a feature of each proposal. It is more interesting to focus on some aspects of the Treasury's original proposals since, with only a few important omissions, they come closest to a neutral system. Along the way, aspects of the President's proposals and the two congressional bills will be compared with the Treasury's proposal.

\section{A. Depreciation}

The Treasury proposal bases tax depreciation on economic depreciation, measured pursuant to the Hulten and Wykoff studies. ${ }^{218}$ Bradley-Gephardt uses a modified form of the prior Asset Depreciation Range (ADR) system. It assigns assets to six classes on the basis of their pre-1981 ADR mid-point lifetimes and the recovery percentage is $250 \%$ divided by the number of years in the class life. ${ }^{219}$ Kemp-Kasten modifies the ACRS system by lengthening the useful life of assets (for example, three to four years, five to six years) and permitting capital recovery percentages over the useful life that sum to more than $100 \%$ for each asset class. ${ }^{220}$ An asset assigned to the four-year class, for example, is permitted a total recovery over the four years of $106 \%$ of the investment in the property. The President's proposal divides depreciable assets into six classes, each with a specified recovery period, and applies a declining balance depreciation rate to each class, switching to a straight-line rate in a specified recovery year. ${ }^{221}$ Assets are assigned to the six classes based on economic depreciation rates (as measured in the Hulten and Wykoff study), so as to minimize the variance in observed economic depreciation rates for assets in the same class. The actual depreciation rate applied to each class, however, is the sum of the economic depreciation plus an additional rate as an investment incentive. ${ }^{222}$ The additional incentive rate applied to each class is chosen so that the combination of the specific recovery period and total depreciation rate yields an $18 \%$ effective tax rate on all machinery and equipment and a $25 \%$ effective tax rate on structures, assuming the $33 \%$ proposed marginal corporate tax rate and a $4 \%$ real after-tax rate of return. ${ }^{223}$ All four proposals eliminate the investment tax credit. ${ }^{224}$ The Treasury proposal, the President's proposal, and the Kemp-Kasten bill index depreciation deductions. ${ }^{225}$

218. See 2 Treas. Report, supra note 207, at 152-76. For a discussion of the Hulten and Wykoff Studies, see supra text accompanying notes 109-118.

219. H.R. 800, supra note $209, \$ 301$.

220. H.R. 777, supra note $210, \$ 301$.

221. Pres. Proposals, supra note 208, at 138-47. The switch to the straight-line depreciation method is made in the recovery year in which, assuming a half-year convention, the straight-line method yields a higher allowance than the declining rate.

222. Id. at 146 .

223. Id. at 147 (Table 7.01-5).

224. H.R. 800, supra note 209, \$ 201; H.R. 777, supra note 210, \$ 201; 2 TREAs. REPORT, supra note 207, at 173-75; Pres. Proposals, supra note 208, at 160-63.

225. H.R. 777, supra note 210, \& 301; Treas. Report, supra note 207, at 158-59; Pres. Proposals, supra note 208 , at $138-39$. 
The proposals of the Treasury and the President attempt to measure correctly economic income since they apply economic depreciation, eliminate the investment tax credit, and index the depreciation deduction. ${ }^{226}$ The Treasury's proposal is intended to produce effective tax rates on equity investments approximately equal to statutory rates. The President's proposal is intended to provide a neutral investment incentive through the depreciation system by increasing the depreciation rate above economic depreciation so that the effective tax rate applied to all equity investment in machinery and equipment is the same. ${ }^{227}$ Thus, both proposals are designed on the principle that a neutral depreciation system is one which yields the same effective tax rates for all depreciable assets. ${ }^{228}$ The Treasury's proposal is more neutral, however.

Bradley-Gephardt is designed to approximate economic depreciation at a $6 \%$ inflation rate and a $10 \%$ discount rate. ${ }^{229}$ Since Bradley-Gephardt applies assumed inflation and discount rates and does not index depreciation, tax depreciation can differ from economic depreciation and, accordingly, effective tax rates on equity investment can be higher or lower than statutory rates. ${ }^{230}$ Bradley-Gephardt clearly trades off accuracy through indexation of depreciation expense against administrative concerns with respect to indexation.

The present value of the depreciation deductions under Kemp-Kasten approximates expensing at an assumed $3.5 \%$ real rate of return. As a result, this system-equivalence to expensing, indexation, and elimination of the investment tax credit-is designed to yield approximately a zero effective tax rate on equity investment. It could still yield substantially varying effective tax rates because actual real rates of return can vary and because ACRS lumps assets with varying economic depreciation rates into too few recovery periods. Presumably Kemp-Kasten presents this more complicated substitute to actual expensing because of the cash flow impact of expensing on federal government revenues and the problem of the asymmetry in treatment of business income and losses. ${ }^{231}$

Among the four proposals, the proposals of the President and the Treasury probably provide the best measurement of capital allowances for equity investments in depreciable property under an income tax system.

226. The President's proposal also would tax all gain or loss upon dispositions of depreciable property as ordinary income. Pres. Proposals, supra note 208, at 142.

227. Gravelle estimates that the President's proposal will yield an efficiency gain of $1.1 \%$ of GNP. This gain results not only from a more neutral depreciation system but also from reductions in distortion between debt and equity and between corporate and noncorporate investments. Gravelle, Tax Reform and Efficiency Gains from the Reallocation of Investment, 29 TAX NotEs 651, 651 (1985).

228. Fact Sheet on Bradley-Gephardt "Fair Tax Act of 1983" at 3.

229. Its sponsors have stated, however, that any variance from statutory rates will be uniform across assets. Statement by Senator Bill Bradley before the National Press Club 4 (Apr. 14, 1983).

230. For a discussion of the asymmetry of treatment of business income and losses, see supra text accompanying notes 158-67.

231. For a discussion of an ex post depreciation system, see supra text accompanying notes 117 . 23. 
Since gains and losses from relative price changes are not accrued, however, the depreciation deduction under both proposals is not based on an ex post determination of replacement cost and therefore is not totally neutral. ${ }^{232}$ The elimination of the investment tax credit as well as ACRS reduces the problem of asymmetry in treatment of business income and losses. The President's investment incentive is incorporated into the depreciation rate and is not "front-ended" so it does not create the same magnitude of difficulty as ACRS and the investment tax credit do under that asymmetry. Neither the President nor the Treasury proposes any changes in the present treatment of the carryover of net operating losses without interest.

\section{B. Inflation Adjustments}

The Treasury originally proposed to index depreciation, inventory, indebtedness, and capital assets for general price level changes. ${ }^{233}$ Thus, it chose to index substantially all of the tax base rather than to apply any partial indexation scheme. Bradley-Gephardt, in contrast, provides no indexation of the tax base, nor any ad hoc adjustments (except to the extent that depreciation deductions are accelerated). This omission, which in the event of higher future inflation could cause substantial mismeasurement of the tax base, varying across assets and industries, is the most substantial fault in the Bradley-Gephardt bill from the standpoint of neutrality.

Kemp-Kasten provides partial indexation of depreciation and capital gains. ${ }^{234}$ Depreciation is indexed like the Treasury's proposal. At the option of the taxpayer and in lieu of a preferential capital gains tax rate, capital gains are indexed for assets now treated as capital assets, excluding a creditor's interest in property (e.g., bonds), certain net lease property and preferred stock, and stock in $\mathbf{S}$ corporations and in certain foreign corporations. ${ }^{235}$

The President's proposal provides indexation of depreciation, FIFO inventories, and capital gains. ${ }^{236}$ It proposes that the present exclusion for net capital gain be decreased from $60 \%$ to $50 \%, 237$ and that noncorporate taxpayers be given an election, beginning January 1,1991 , to index the basis of capital assets in lieu of the 50\% exclusion. ${ }^{238}$ The indexation proposals of Kemp-Kasten and the President create arbitrage opportunities because of the indexation of real assets without simultaneous indexation of financial assets. Nevertheless, some economists have argued that a system like that of KempKasten and the President is better than no indexation at all.239 Taxpayers have the option to index inventory by electing LIFO accounting (and the

232. 2 TREAS. REPORT, supra note 207, at 177-200.

233. H.R. 777, supra note 210, $\$ \$ 231$ (capital gains), 301 (depreciation).

234. For a discussion of the problems of partial indexation, see supra text accompanying notes 203-06.

235. Pres. Proposals, supra note 208, at 138-39, 166-69, 175.

236. Id. at 168 .

237. Id. at 169

238. Id.

239. See supra text accompanying notes 196-202. 
President's proposal would index FIFO inventory), and nominal interest rates may adjust with inflation so that debt is somewhat indexed. Accordingly, the two major problems with measurement of the tax base for inflation are depreciation and capital assets; and Kemp-Kasten and the President provide inflation adjustments for both.

Only the Treasury proposal includes indexation for debt. The inflation adjustment for debt can be handled in several ways. As discussed previously, ${ }^{240}$ the proper adjustment is made by multiplying the outstanding loan principal by the inflation rate. Alternatively, the same adjustment can be determined by multiplying the nominal interest times a fraction the numerator of which is the inflation rate and the denominator of which is the nominal interest rate on the loan. ${ }^{241}$ Assume, for example, that the loan principal is $\$ 1,000$, the nominal interest rate is $15 \%$, and the inflation rate is $10 \%$. The creditor receives nominal interest of $\$ 150$ and has an inflationary loss with respect to the loan principal of $\$ 100, \$ 1,000$ loan principal times the $10 \%$ inflationary rate. Alternatively, the inflationary loss of $\$ 100$ can be calculated as the product of the nominal interest of $\$ 150$ multiplied by the fraction $10 \% / 15 \%$. These inflation adjustments reflect partial accrual accounting of the changes in value of the debt due to changes in general price levels. Under strict realization accounting, these changes would not be realized except upon sale or repayment of the loan principal.

The Treasury proposal does not follow exactly either of these methods. Presumably, partial accrual methods are rejected as too complicated. The calculation must be applied with respect to each outstanding loan, and loan principals and nominal interest rates with respect to each loan can vary during the tax accounting period. The Treasury proposal, on the other hand, does not discuss at all the possibility of indexing loan amortization payments, possibly because this method does not work for all financial assets; for example, it does not work for savings accounts. The Treasury proposes instead the following method: the taxpayer's net interest income or expense would be multiplied by a fraction, the numerator of which is the inflation rate and the denominator of which is the inflation rate plus an assumed real rate of return of $6 \% .242$ This product would be the amount of interest income or expense excluded from the tax base. The denominator of the fraction is thus constant for all rates of interest and may not equal the actual nominal rate on the actual debt. ${ }^{243}$ This method also incorporates a type of realization accounting since it applies only when interest receipts or payments occur or

240. See supra text accompanying notes 167-206.

241. For a discussion of the equivalence of making an adjustment of the interest or of the principal, see V. TANZI, supra note 169, at 54-56.

242. See 2 Treas. RePORT, supra note 207, at 193-95.

243. For example, assume that the inflation rate is $7 \%$, the real rate of interest is $5 \%$, and the creditor is receiving $12 \%$ interest on a $\$ 100$ loan. The creditor's nominal interest income is $\$ 12$, and his real interest income is $\$ 5$. Under the Treasury's proposal, the creditor reports $\$ 5.54$ as interest income: $\$ 12$ nominal interest income - $(\$ 12 \times 7 / 13)$. The interest income is overstated because the Treasury proposal assumes in all cases a real rate of return of $6 \%$. The correct exclusion ratio would be $7 / 12$ and the taxable interest $5 \%$. Whenever the real rate of return is less than $6 \%$, interest 
accrue. If the loan principal changes in value due to inflation, in a tax accounting period when no interest receipt or payment is made, that change in value will not be reflected in the tax base of cash-accounting taxpayers during that accounting period. ${ }^{244}$ Thus two primary reasons probably explain the Treasury's method of indexation for debt: it is easier to calculate, and it follows more closely the realization doctrine since it applies to payments of interest income and expense as they occur or accrue. The President's proposal dropped the Treasury's proposal to index indebtedness. It was probably eliminated not only because it would contribute substantial complexity to the Code, but also because it was too inadequate a proxy for correct indexation of debt. The exclusion fraction was a proxy for a fraction based upon the actual nominal interest rate on each debt; ${ }^{245}$ the timing question of whether indexation of debt should follow accrual accounting or strict realization accounting was inadequately analyzed; and as discussed in the next section, a substantial amount of interest deductions (particularly deductions for home mortgage interest expense) was excluded from the Treasury's indexation proposal.

\section{Interest Deduction Limitation}

Although the proposals of the Treasury and the President substantially broaden the tax base, some substantial gaps remain. Important omissions include: imputed income from home ownership and consumer durables, income from state and local bonds, accrual of unrealized gains and losses, and income on qualified retirement accounts. The President's proposals, moreover, include an investment incentive in the depreciation method, ${ }^{246}$ and retain the preferential capital gains tax structure. As a result of these omissions and investment incentives, the proposals constitute a mixture of income tax measurement (for example, depreciable property), consumption tax measurement (for example, homes, state and local bonds, retirement accounts), and "somewhere-in-between-the-two" measurements (for example, realization of gains and losses). As previously discussed,247 elimination of tax arbitrage in such circumstances requires interest tracing

income and deduction will be overstated; when the real rate of return is greater than $6 \%$, interest income and deduction will be understated.

244. A stricter realization accounting would apply the Treasury's proxy only to interest-bearing deposits and adjust time limited debt, such as certificates of deposits, notes, bonds, only upon sale or repayment of the debt.

245. For a discussion of the overgenerous benefit of the Treasury's proposal to financial intermediaries, see Forman, Treasury's Interest Indexing Proposal: Either a Bank or a Net Lender Be, 26 TAX Notes 856, 859-60 (1985).

246. Because of this depreciation investment incentive, the President's proposal includes in the tax base for the corporate minimum tax $25 \%$ of the deduction for net interest expense, but not in excess of the amount (if any) by which the depreciation deduction for personal property exceeds the deduction which would have been allowed under a real economic depreciation system as proposed originally by the Treasury. Pres. Proposals, supra note 208, at 336-37. The President's proposal states that the $25 \%$ fraction was chosen to approximate conservatively the portion of the interest representing an inflation premium rather than the real cost of borrowing money. Id. at 397 .

247. Supra text accompanying notes 139-57. 
rules to determine the extent to which tax favored investments are debtfinanced. The interest deduction on such debt-financed investment should then be disallowed (for consumption tax treatment) or calibrated (for the somewhere-in-between tax treatment). Rather than proposing such a tracing rule, the proposals of the Treasury and the President adopt the interest limitation approach of section 163(d), but with broader scope and tighter limitations.

Under these proposals, all nonbusiness interest deductions would be limited by the amount of investment income plus income from limited partnerships and $\mathbf{S}$ corporations. ${ }^{248}$ The rationale for this limitation is that any such excess interest is related to income that is not taxed or to consumption. Disallowance of the deduction for indebtedness with respect to untaxed income affects arbitrage opportunities. Disallowance of interest on indebtedness for consumption reflects the viewpoint that such consumptionrelated expenses are not properly deducted. Both proposals exempt from the limitation, however, mortgage interest expense with respect to a taxpayer's principal residence plus $\$ 5,000$ of additional interest. ${ }^{249}$ Neither gives any

248. Interest subject to the current investment limitation of $\S 163(\mathrm{~d})$ would be expanded to include: (a) all interest not incurred in connection with a trade or business (other than interest on debt secured by the taxpayer's principal residence, to the extent such debt does not exceed the fair market value of the residence), (b) the taxpayer's share of all interest expense of $\mathbf{S}$ corporations (other than $\mathrm{S}$ corporations in which the taxpayer actively participates in management), and (c) the taxpayer's distributive share of all interest expense of limited partnerships in which the taxpayer is a limited partner. Investment income for purposes of the matching rule would be defined as it is now under $\S 163(\mathrm{~d})$ but would be expanded to include the taxpayer's share of all income of $S$ corporations not managed by the taxpayer, and the taxpayer's distributive share of all income of limited partnerships in which the taxpayer is a limited partner. See 2 TREAs. REPORT, supra note 207, at 332; Pres. Proposals, supra note 208, at 323.

249. See 2 Treas. Report, supra note 207, at 332; Pres. Proposals, supra note 208, at 324.

The Bradley-Gephardt and Kemp-Kasten bills place some limitations on interest deductions. Bradley-Gephardt allows an unlimited home mortgage interest deduction from the tax base to which the normal tax rate of $14 \%$ is applied. H.R. 800, supra note 209, $\$ 232$. Accordingly, while retaining an unlimited and unindexed deduction, the tax reduction value of the deduction is limited to the tax rate of $14 \%$. This is equivalent to providing a tax credit of $14 \%$. In contrast, the proposals of the Treasury and the President allow an unlimited and unindexed interest deduction at the applicable marginal tax rate (either $15 \%, 25 \%$, or $35 \%$ ). The interest deduction under Bradley-Gephardt is limited to indebtedness to acquire, construct, or substantially rehabilitate the home. Under BradleyGephardt, all other nonbusiness interest is deducted only to the extent of net investment income for purposes of both the normal tax rate of $14 \%$ and the surtax rates of $12 \%$ and $16 \%$. Like the proposals of the Treasury and the President, it extends the interest limitation rule to all nonbusiness interest, except home mortgage interest, and covers passive investments in limited partnerships and $S$ corporations. It does not contain an exception for an additional $\$ 5,000$ of interest. Thus, the Bradley-Gephardt interest limitation rule is more strictly drafted than the proposals of the Treasury and the President in the following ways: (1) the unlimited home mortgage interest deduction is limited to the $14 \%$ normal tax rate and applies to indebtedness to acquire, construct, or substantially rehabilitate the home; and (2) all other nonbusiness interest is subject to the matching requirement without any $\$ 5,000$ exception. Bradley-Gephardt therefore provides less opportunity for tax arbitrage.

As can be seen from Table 17 in the text, the tax base of the Kemp-Kasten proposal with respect to capital income is narrower than that under the Treasury's proposal or the Bradley-Gephardt bill. Also, the Kemp-Kasten interest limitation rule, as shown in the next paragraph, is more liberal than the Treasury's proposal. Thus, more opportunities for tax arbitrage remain under the Kemp-Kasten bill. Also, Kemp-Kasten, like the President's proposal, has different marginal tax rates for ordinary income and capital gains and different marginal tax rates for individuals and corporations, so that tax 
reason for the home mortgage exclusion; one can only conclude that it reflects political realism and President Reagan's objection to any limitation to the home mortgage interest deduction. The $\$ 5,000$ amount is less than the $\$ 10,000$ amount currently in section 163 (d) and presumably is included to eliminate application of the interest limitation rule for most individual taxpayers; however, it is lower than the $\$ 10,000$ amount to tighten the limitation rule. The Treasury proposal states that in 1981 only $3.3 \%$ of individual taxpayer returns claimed itemized deductions for nonmortgage interest in excess of $\$ 5,000 .^{250}$ Thus, the $\$ 5,000$ figure appears to be a decision in favor of administrative convenience.

These same amounts of interest deductions (home mortgage interest plus $\$ 5,000$ ) are also excluded from debt indexation under the Treasury's proposal. ${ }^{251}$ Thus, taxpayers can deduct nominal interest payments with respect to all of the debt-financed investment in their principal residence plus $\$ 5,000$ of interest paid with respect to debt-financed investment in other tax favored assets. The creditor with respect to these same debts can fully index the interest receipts, however. Given the substantial base broadening of the Treasury's proposals, the omission of home mortgage interest from the limitation gives a tremendous incentive for taxpayers to overinvest in housing

arbitrage opportunities exist due to these rate differentials. For tax rates, see H.R. 777, supra note 210, \$\$ 101, 102, 231; Pres. Proposals, supra note 208, at 1, 119.

The Kemp-Kasten bill allows an unlimited and unindexed deduction for interest paid with respect to home mortgage and educational loans. H.R. 777, supra note $210, \S 228$. Home mortgage loans must relate to acquisition, construction, or rehabilitation of residential property. The bill disallows any deduction for any other consumer interest expense (any that is not related to business or investment activities). The bill provides no tracing rules, so a taxpayer with savings can avoid this limitation in the same manner that the $\$ 265$ limitation with respect to tax exempt bonds is avoided now. Kemp-Kasten makes no modification to the present $\$ 163$ (d) matching rule, so it continues to exclude from its coverage passive investments in limited partnership interests and $\mathrm{S}$ corporations. It also retains the present $\$ 10,000$ exemption from coverage of the limitation. Thus, the only tightening of the interest limitation rule provided by Kemp-Kasten is the limitation on the deduction of consumer interest, and it possesses the same defects as the present $\$ 265$ limitation rule.

250. 1 TREAS. RePORT, supra note 207 , at 83.

251. See 2 TREAS. REPORT, supra note 207, at 194-95. The Treasury proposal integrates the interest indexation rule and the interest limitation rule as follows. The taxpayer first receives an unlimited and unindexed interest deduction for home mortgage interest. Second, the taxpayer nets other gross interest income and interest expense. If the netting yields net interest income, it is multiplied by the indexation fraction to determine the percentage of income excluded. If the netting yields net interest expense, $\$ 5,000$ is subtracted from this amount; and the excess, if any, is multiplied by the indexation fraction to determine the percentage of the deduction disallowed. The indexed net interest expense is then subjected to the interest limitation rule. See id. at 194-95, 332-33.

The following example illustrates how these rules would operate. Assume the taxpayer has home mortgage interest expense of $\$ 6,000$, interest income of $\$ 500$, dividend income of $\$ 1,500$, and nonbusiness interest expense of $\$ 8,500$. Assume that the inflation rate is $4 \%$ so that the indexation fraction is $40 \%$ (inflation rate/inflation rate + assumed $6 \%$ real rate of interest). The taxpayer is allowed an unindexed and unlimited deduction of $\$ 6,000$ for the home mortgage interest. Next the taxpayer nets the $\$ 500$ interest income against the $\$ 8,500$ interest expense, and the overall net interest expense is $\$ 8,000$. From this amount is substracted $\$ 5,000$, so that the taxpayer is allowed an additional $\$ 5,000$ unindexed deduction for interest expense. The remaining $\$ 3,000$ of net interest expense is indexed so that $40 \%$ of the interest deduction is eliminated. The remaining $\$ 1,800$ is then subject to the interest limitation rule which limits the remaining nonbusiness interest deduction to the amount of investment income of $\$ 1,500$. Accordingly, $\$ 300$ of the interest expense is not deducted and is subject to an unlimited carryover. 
(relative to the amount of housing that they would choose under a neutral income tax) and to finance as much as possible of that investment with debt. ${ }^{252}$

Because the Treasury and the President (but less so) propose in general a broad tax base, application of the matching investment income and nonbusiness interest expense rule may be preferable to a detailed, but more accurate, interest tracing rule; the latter is likely to be harder to write into legislation and for taxpayers to apply. The exclusion of all home mortgage interest from the matching rule seems questionable, however. Even taking into account political considerations, arguably it is preferable to include home mortgage interest under the limitation rule and increase the $\$ 5,000$ amount to a moderately higher figure. This higher figure could still be set to eliminate the application of the limitation for most taxpayers, who have enough savings to invest only in a home, a car, and some household items. The arbitrage incentive is limited for them anyway by income constraints as well as by their lack of savings. Application of the limitation to home mortgage interest would then operate primarily to eliminate the arbitrage opportunities for wealthier taxpayers who could afford to debt-finance substantial investment in their principal residence and equity-finance through savings their investment in nontax favored investments and consumption.

\section{Accrual of Gains and Losses}

Curiously, after such meticulous detail to many problems of income measurement such as economic depreciation and indexation, any treatment of the problem of deferral through operation of the realization doctrine is totally omitted from the Treasury's proposal. ${ }^{253}$ Few persons seriously consider the possibility of taxing accrued gains and losses for all assets. A reasonable proxy exists, however: imposing an interest charge for the deferral at the time of realization. ${ }^{254}$

The omission of a suggested proxy along these lines is even more curious in light of the Treasury's indexation proposal, for two reasons. First, indexation eliminates the taxation of nominal gains, so that better measurement of gain is assured. Imposing interest on the deferral of real gains is more acceptable than imposing interest on the deferral of a gain

252. Hendershott and Ling have analyzed the expected impact on home ownership of the Bradley-Gephardt, Kemp-Kasten, and Treasury proposals. They concluded that the Treasury's proposal is the most favorable to owner-occupied housing. See 27 TAX Notes 318 (1985); Hendershott \& Ling, The Treasury's Tax Reform Propasal and Housing, 26 TAx Notes 1041 (1985).

253. See id. at 186-87. The Treasury's proposal to index interest receipts and expenses, however, yields partial accrual accounting with respect to loan principal. See the discussion of this indexation proposal supra in the text accompanying notes 240-45.

254. See, e.g., Cong. Budget OfFice, supra note 103, at 70-81; Instrtute for Fiscal Studies, supra note 102, at 129-35. The complexity and accuracy of the proxy should not be underestimated, however. Such a proxy requires the assumption of even accrual over each accounting period, the same after-tax interest charge for all taxpayers (even though nominal interest and marginal tax rates differ among taxpayers), and some kind of averaging device to prevent bunching so long as tax rates are graduated. 
calculated under the present Code which may have little relationship to the real gain. Second, the introduction of indexing requires historial recordkeeping. In particular, such facts as the date of purchase, and of substantial additions and improvements must be known, to determine the proper index; this same information also is needed to calculate an appropriate interest charge. One cannot help but conclude that political balancing again influenced the proposal. A decision may have been made that elimination of the current tax rate differential for capital gains might be politically acceptable if capital gains were indexed along with lowering the top marginal tax rate. Adding an interest proxy to correct for deferral, however, might have been too much to add (in a political sense) along with elimination of the rate preference. The political eye may have been on investments, such as those in high technology, which have benefited most from the present capital gains system.

This guesswork is arguably substantiated by the treatment of capital gains in the President's proposals. These proposals retain the preferential effective tax rate for capital gains, by allowing $50 \%$ exclusion of net capital gains, and propose that noncorporate taxpayers be given the option to index the basis of capital assets in lieu of the $50 \%$ exclusion for tax years beginning on or after January 1, 1991. ${ }^{255}$ The President's proposal specifically states:

Since the Administration proposals would allow elective inflation indexing for capital assets . . . , retention of a capital gain preference, in the long run, must rest on grounds other than its function as an indirect inflation adjustment. The most significant of these other grounds concerns the incentive effect of the preference. There is broad concern that elimination of the capital gain preference would adversely affect saving and investment, and thus impair the capital formation necessary to continued economic growth. Moreover, many argue that, because of risk or other factors, investment needed to generate new and innovative technology would not be pursued at optimal levels absent a favorable rate of taxation. Although it might be possible to address these concerns through a preference limited to particular activities or forms of investment, the complexity entailed in defining and enforcing those limits would substantially offset the simplification benefits of a change from current law. ${ }^{256}$

The President's proposal goes on to mention the justification of preferential rates for capital gains because of the lock-in effects of the realization doctrine. ${ }^{257}$ It mentions the valuation and liquidity difficulties with an accrual method of accounting for unrealized gains and losses, ${ }^{258}$ but it does not mention any proxies for accrual accounting, such as an interest charge for deferral at the time of the realization event. Thus, one cannot help but conclude from the list of justifications, that the only significant justification is the felt need for the preferential effective tax rate for capital gains as a saving

255. Pres. Proposals, supra note 208, at 168-69.

256. Id. at 170 .

257. Id. at 172.

258. Id. 
and investment incentive. The validity of an assumed saving and investment response is far from clear. ${ }^{259}$

In addition to providing no solution to the general deferral problem under the realization doctrine, none of the proposals makes any changes in the present rule that the basis of all assets adjust to their fair market value at death. This omission clearly reflects political judgments again, no doubt in part due to the brief experience in the 1970's with a carryover basis rule. ${ }^{260}$

Notwithstanding political judgments, the omission of a proxy for deferral from all four proposals, and the inclusion of preferential effective tax rates for capital gains in the President's proposal and in the Kemp-Kasten bill, cause serious mismeasurements in the income tax base, the effects of which have been thoroughly explored elsewhere. ${ }^{261}$ One well-known advocate of the consumption tax has referred to the problem of deferral as the Achilles' heel of the income $\operatorname{tax},{ }^{262}$ and all four proposals continue to support the correctness of his charge. Dealing with the problem of deferral must be a part of any tax reform proposal that purports to address conscientiously the neutrality goal in taxing capital income.

\section{E. Integration}

Finally, the Treasury proposes to effect partial integration of corporate and personal income taxes by permitting corporations a deduction for $50 \%$ of dividends paid from earnings which have borne the corporate tax. ${ }^{263}$ The deduction for dividend payments, along with indexation of interest payments, would help eliminate the current bias in favor of debt capitalization. The proposal does not explain the choice of the 50\% figure. Presumably, reasons for this degree of integration include the amount of lost revenue from deducting a larger percentage of dividends received and international

259. See generally the discussion supra in the text accompanying notes $31-40$, of the interest elasticity of saving with respect to the real after-tax rate of return.

Economists debate the extent to which realization of capital gains is sensitive to tax rates on capital gains and to the present tax rules on realization. See M. FeLDSTEIN, supra note 17, at 216-54. Economist Feldstein concluded that a more active stock market would be encouraged by altering the taxation of capital gains, including lowering the rate, indexing the basis, constructive realization of gains at death, taxing accrued gains directly or retroactively with interest, or allowing tax-free rollovers. Id. at 250 . He did not analyze the specific effect of each of these various changes in the taxation of capital gains, nor does the Treasury Department in its tax reform proposals. For a discussion of the issue whether tax rate reductions stimulate taxpayers to realize so much more capital gains that the tax revenue from the realization exceeds the lost revenues from the tax cut, see, for example, Minarik, Professor Feldstein on Capital Gains-Again, 19 TAX Notes 475 (1983).

260. The Tax Reform Act of 1976 made I.R.C. $\$ 1014$ inapplicable with respect to much property acquired from individuals who die after December 31, 1976, and enacted I.R.C. $\$ 1023$ which provided a carryover basis for such property. Congress repealed $\$ 1023$ in the Crude Oil Windfall Profits Tax Act of 1980, Pub. L. No. 96-223, $\$ 401$ (a), 94 Stat. 229, 299. The repeal of $\$ 1023$ was most likely the result of the complexity and technical difficulties of $\S 1023$ and a basic resistance to the tax increase it would have caused.

261. For numerical examples of the impact of deferral on effective tax rates, see W. ANDREWs, Basic Federal Income Taxation 206-10 (2d ed. 1979).

262. See Andrews, The Achilles' Heel of the Comprehensive Income Tax, in New Directions in Federal TAX POLICY FOR THE 1980s, 278 (C. Walker \& M. Bloomfield eds. 1983).

263. 2 TREAs. REPORT, supra note 207, at 134-44. 
comparisons with the degree of integration adopted by other developed countries. ${ }^{264}$ Neither the Bradley-Gephardt nor Kemp-Kasten bill contains any integration provisions. The President's proposal reduces the Treasury's dividend-paid deduction from $50 \%$ to $10 \%$ of dividends paid from earnings which have borne the corporate tax. ${ }^{265}$ No specific reason is given for reducing the percentage of the deduction, but it is most likely the result of revenue concerns since the President's proposal contains investment incentives, such as the enhanced depreciation rate in excess of economic depreciation and the preferential effective tax rate for capital gains, which were not in the Treasury's original proposals and which reduce tax revenues.

\section{F. Summary}

The Treasury proposal with respect to taxation of capital income is a curious mix of choices which reflects proper income measurement and (improper?) political judgments in favor of certain investment advantages. It goes much further than the Bradley-Gephardt bill toward proper measurement of capital income, particularly in the event of higher levels of inflation. Unlike the Kemp-Kasten bill, the Treasury proposal substantially eliminates tax preferences for capital investment as granted in ERTA. The President's tax proposals retained much of the excellent neutrality features of the Treasury proposals, including economic depreciation, with the addition of a neutral investment incentive for depreciable assets, and indexation, with the exception of interest indexation. Measured against the neutrality criterion, the Treasury proposal's most serious omissions were continuing the unlimited deduction for home mortgage interest and refusing to tackle the fundamental problem of deferral. As between these two flaws, the latter seems less defensible even to a purist. The President's proposals have these same flaws, enhanced by the retention of the preferential effective tax rate for capital gains, and adds to them the failure to index financial assets while indexing real assets.

\section{$\mathrm{V}$ \\ Conclusion}

The four years of the first Reagan Administration have spawned much controversy with respect to income taxation of capital. Much of the poor economic performance in the late 1970's and early 1980's was attributed to the overtaxation of capital income resulting from the interaction of an unindexed tax base and high levels of inflation. Some economists argued,

264. For a discussion of these and other considerations taken into account by the Treasury Department, see Sheppard, Corporate Tax Integration, The Proper Way to Eliminate the Corporate Tax, 27 Tax NotEs 637 (1985). See also the discussion of foreign integration systems and treatment of foreign shareholders in Pres. Proposals, supra note 208, at 127-29. For a discussion of some foreign integration methods, see, for example, H. Ault \& A. Radler, The German Corporation Tax REFORM LAW 1977 (1977); Gourevitch, Integration of Corporate and Shareholder Taxes, in INCOME: ThE EUROPEAN EXPERIENCE (1977).

265. See Pres. Proposals, supra note 208, at 122. 
however, that effective tax -rates of capital during this time period were not higher as a result of inflation and that, in any event, the slowdown in economic growth could only be attributed in small part to the income tax. Notwithstanding this lack of consensus, the Reagan Administration and Congress responded in 1981 as if income taxation of capital were the culprit. ERTA accordingly lowered the effective tax rates of capital income. It did so unevenly among types of investments and left the income tax base unindexed. As a consequence, the dispersion of effective tax rates on various forms of investment increased. As the inflation rate was lowered successfully, the ERTA system created very low positive, and even negative, effective tax rates for many investments. Gradually, more attention has been drawn to the misallocation effects of varying effective tax rates and of negative tax rates, so that a larger consensus has emerged that capital income should be taxed more neutrally with respect to investment choice.

A substantial weakness of the income tax, however, has always been measurement of capital income. Its detracters like to point out that even if Congress had the political will to establish a neutral income tax, such a tax cannot be accomplished sufficiently in actual legislation. In the last ten years, however, many economists and some lawyers have explored ways to measure capital income more accurately. As described in Section III, most of the problems of measuring capital income have been largely solved by these writers, and the necessary features of a neutral income tax have never been better understood than they are today. It is now as feasible (although not as easy) to enact a neutral income tax as it is to enact neutral taxation of capital income through a consumption tax. The Treasury Department's proposal for tax reform made in November and December 1984 further demonstrates this feasibility. The Achilles' heel of the income tax is not that capital income cannot be measured satisfactorily. We know how to accomplish satisfactory measurement with legislation that can be applied by taxpayers and administered by the government. The remaining question is outside the domain of tax policy analysts: where is the political will to achieve the goal of neutrality? 
